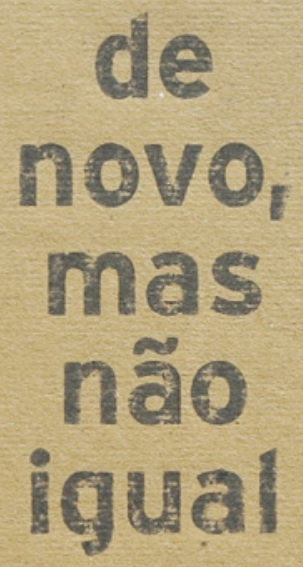

Para assisitir o video sobre o trabalho, clique aqui. 


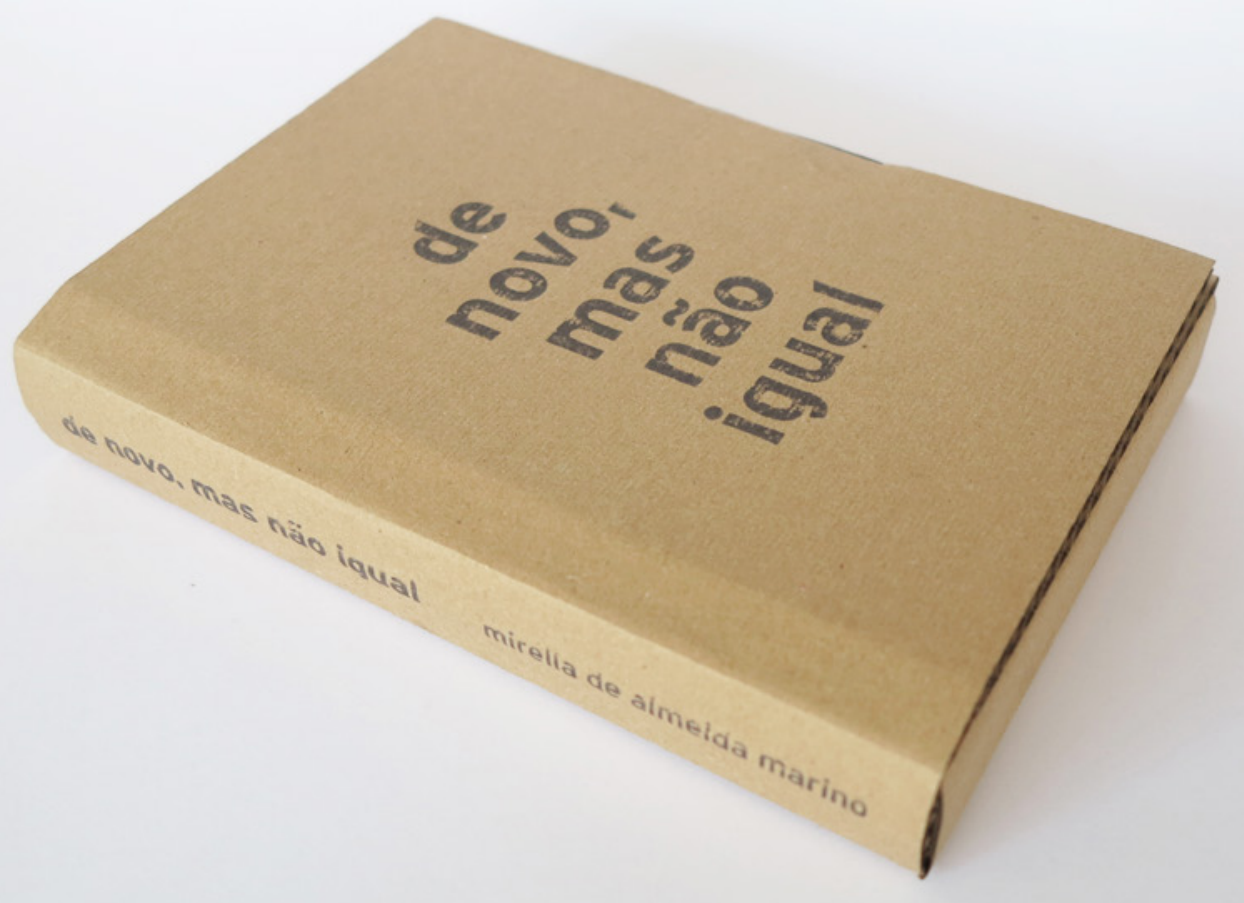


de novo, mas não iqual mirella de aimeida marino 


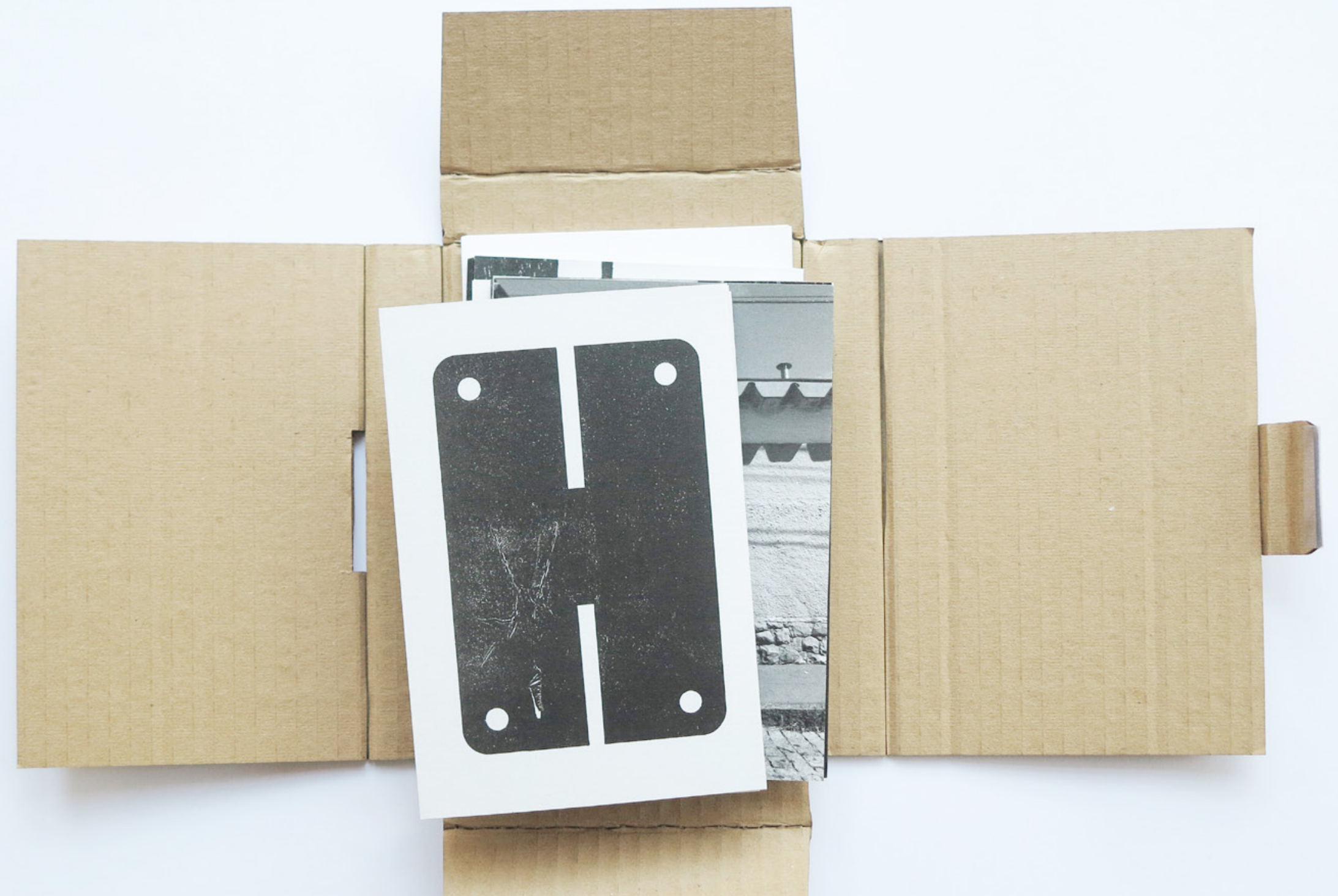



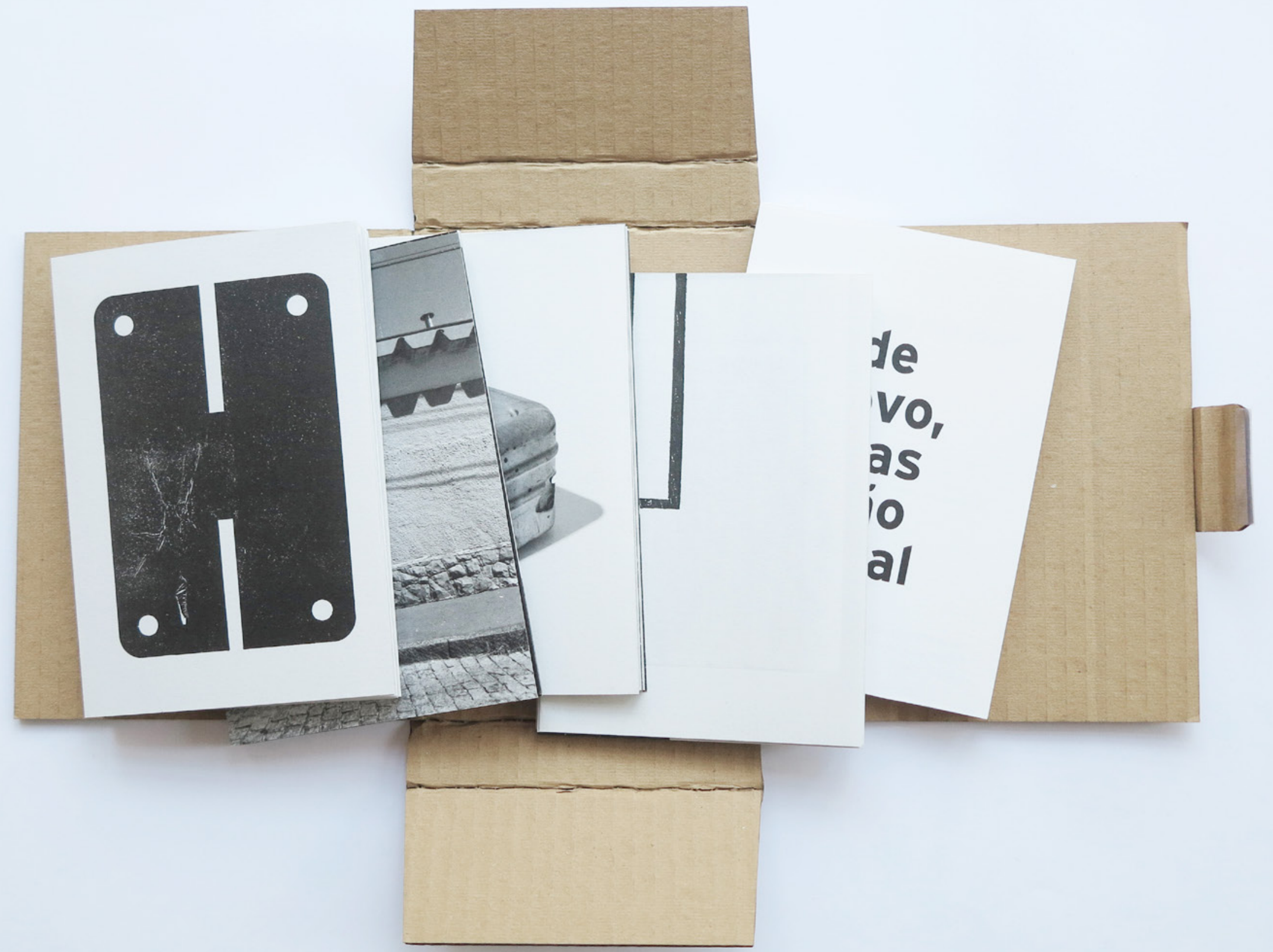


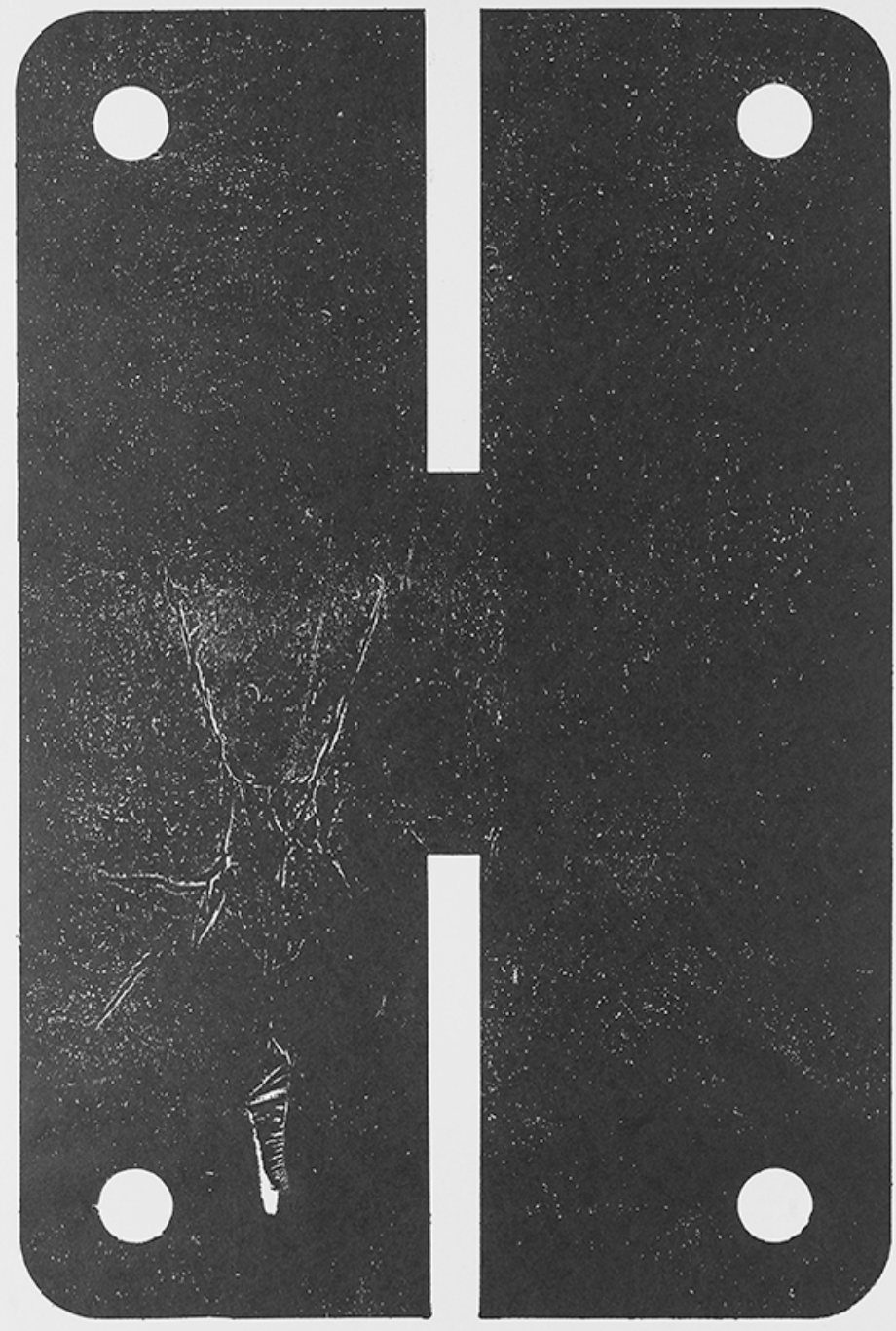



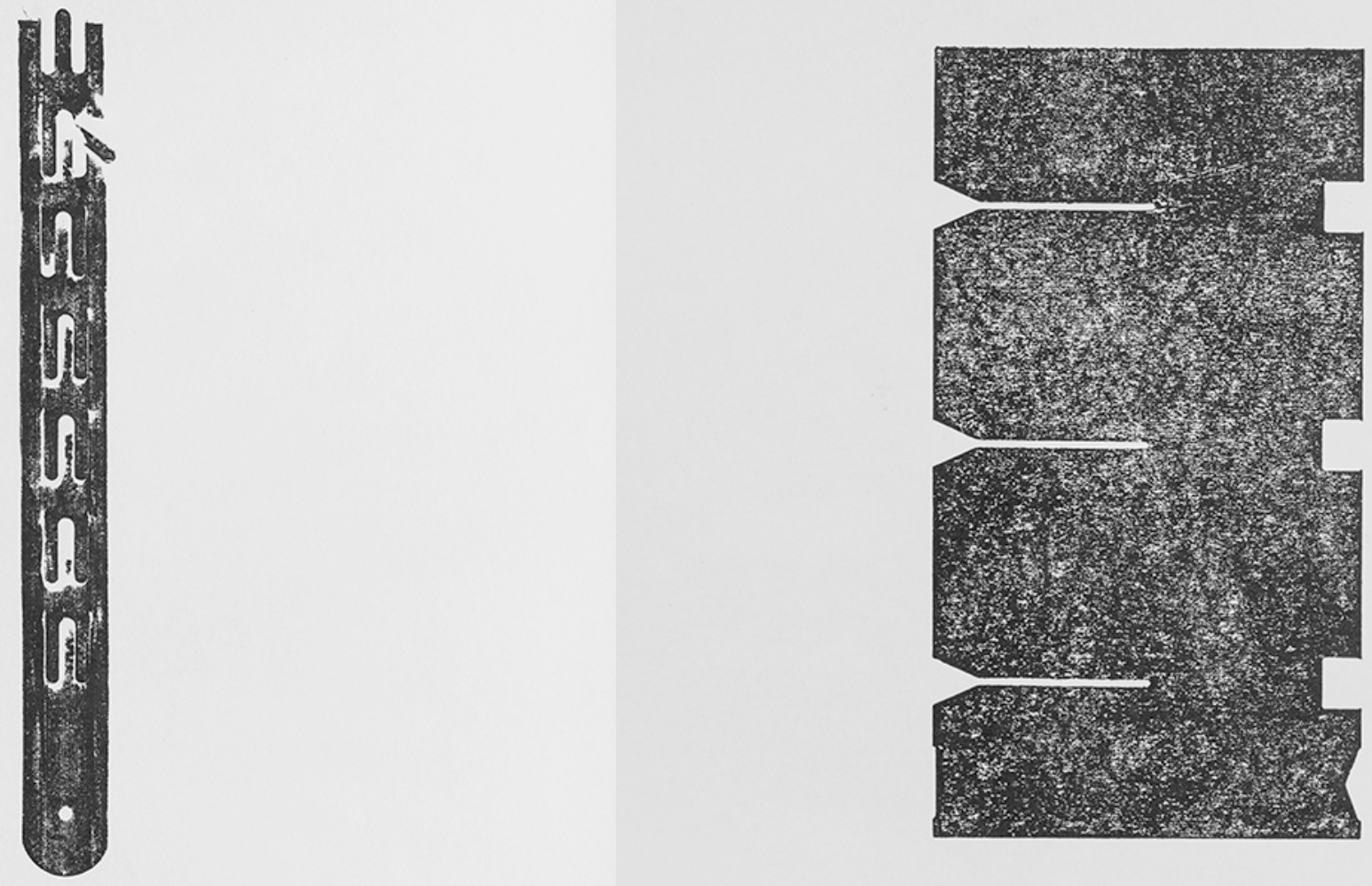

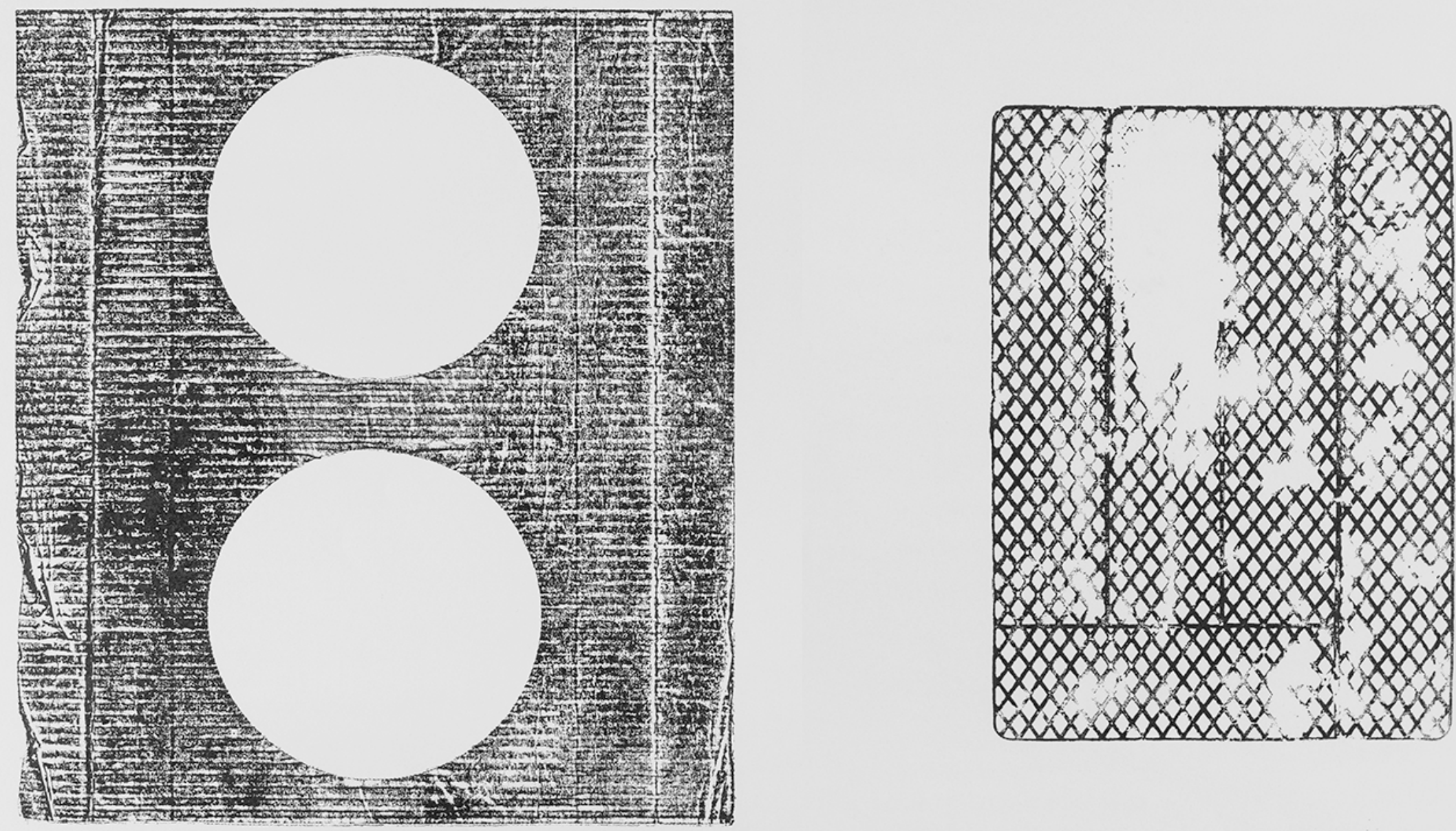

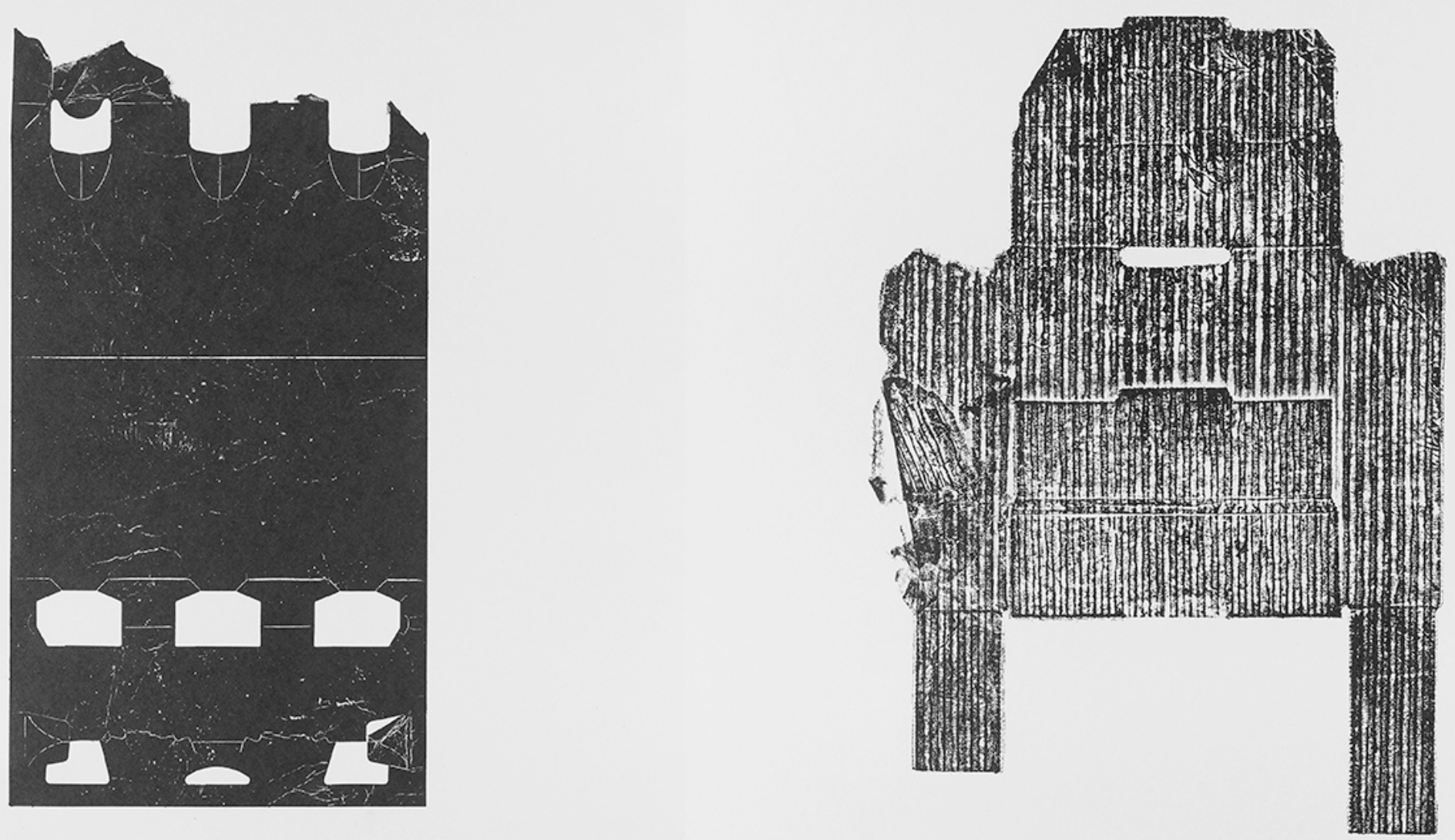

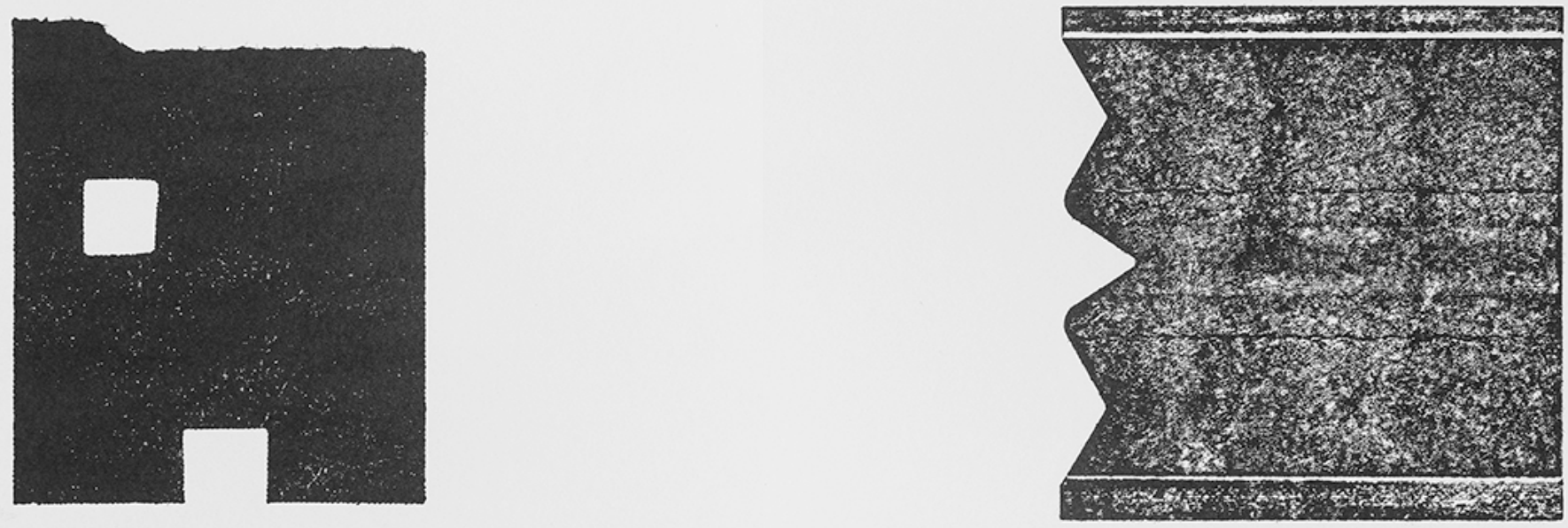

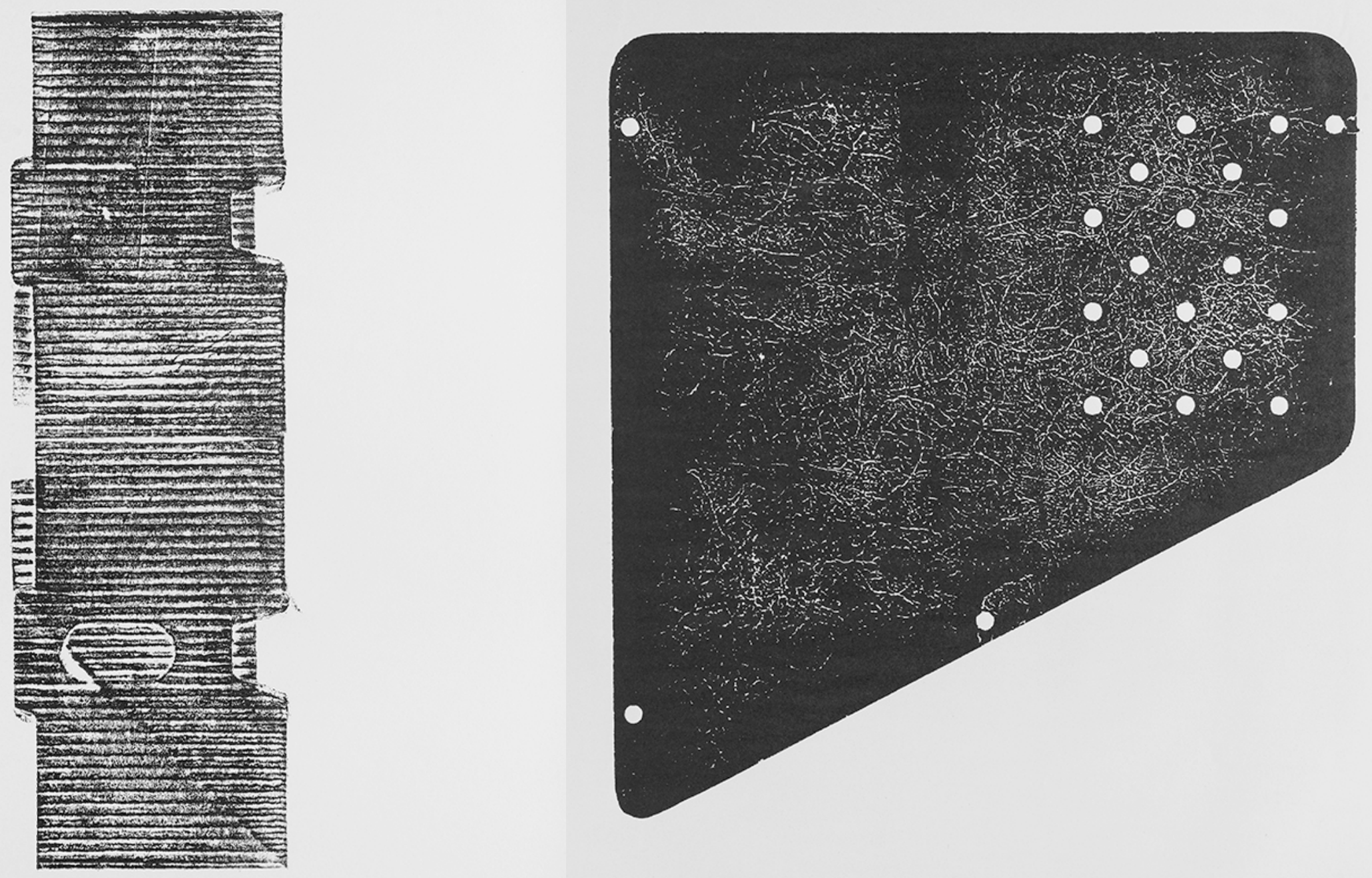

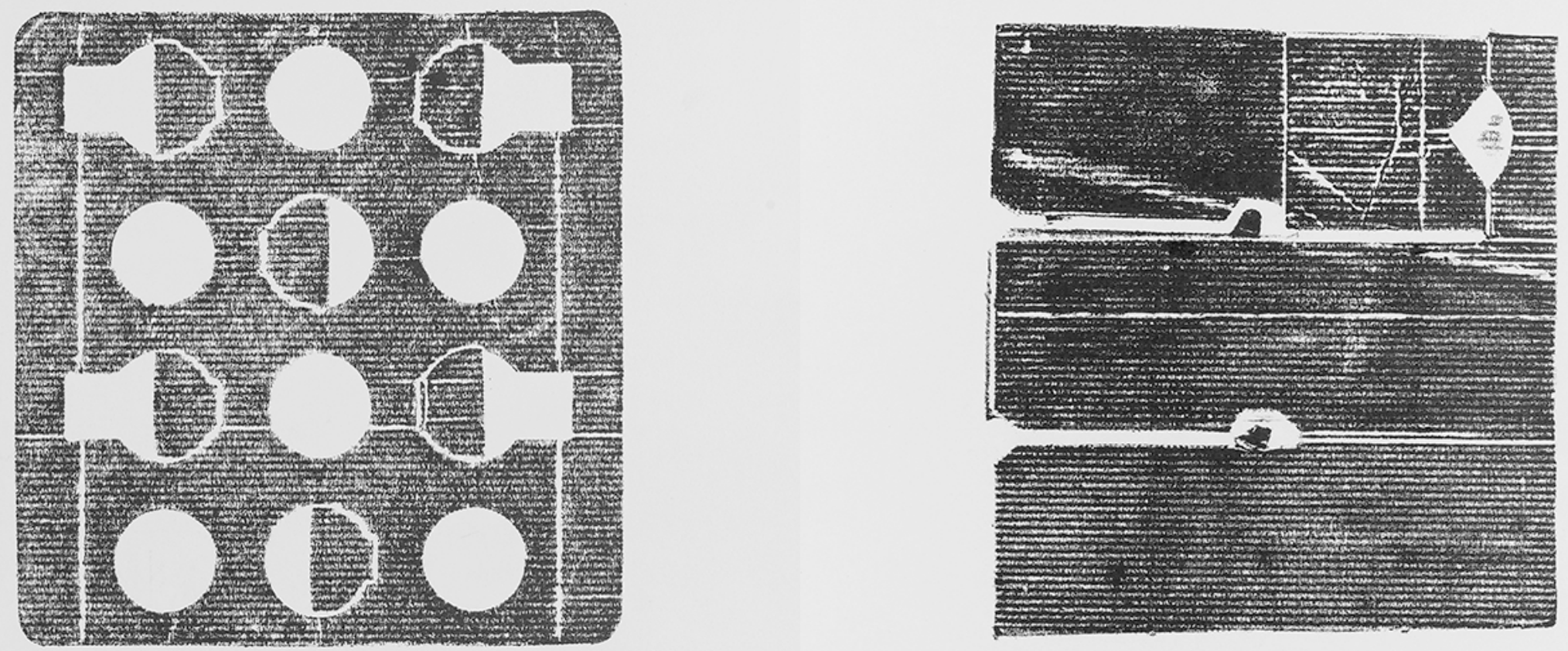

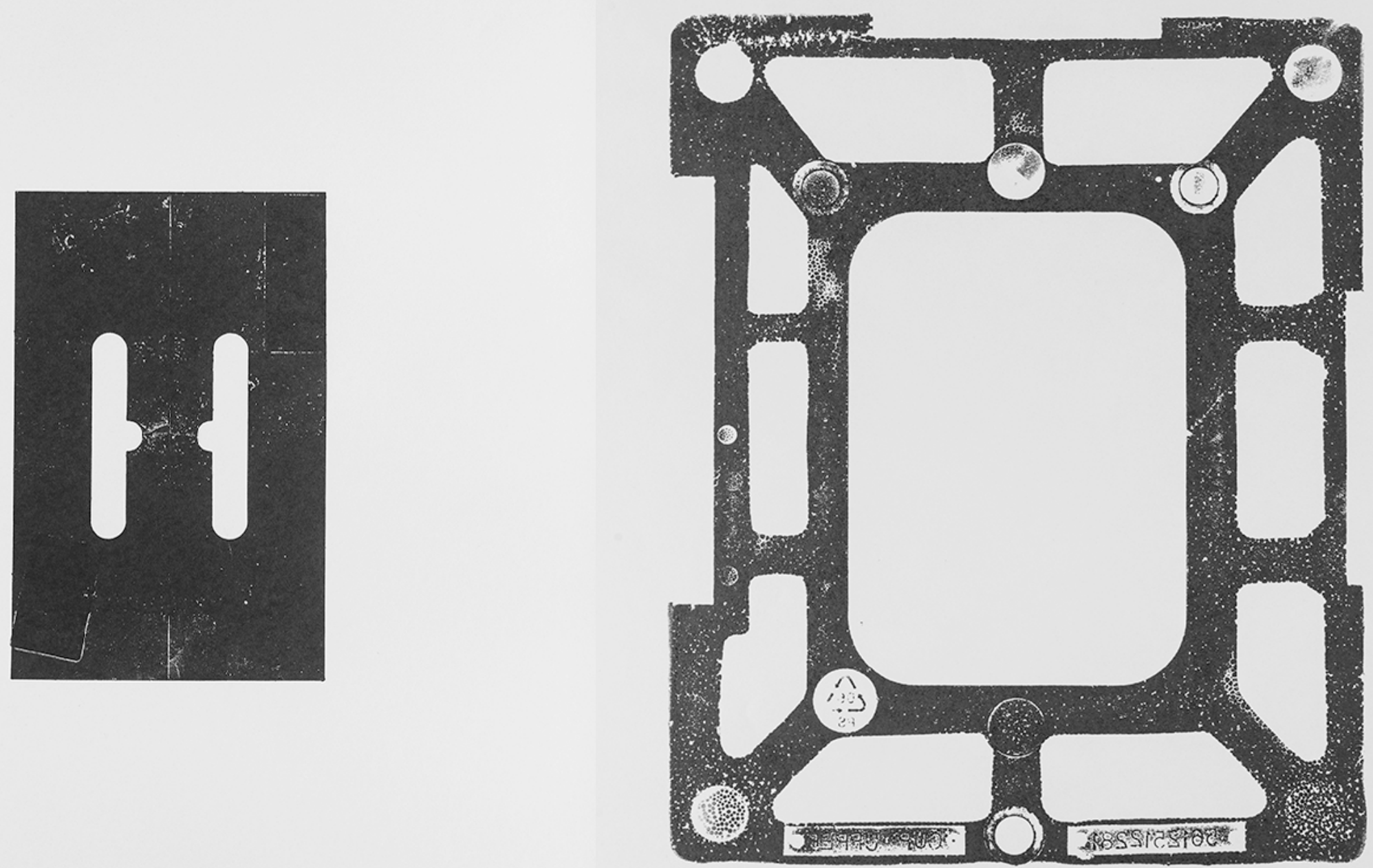

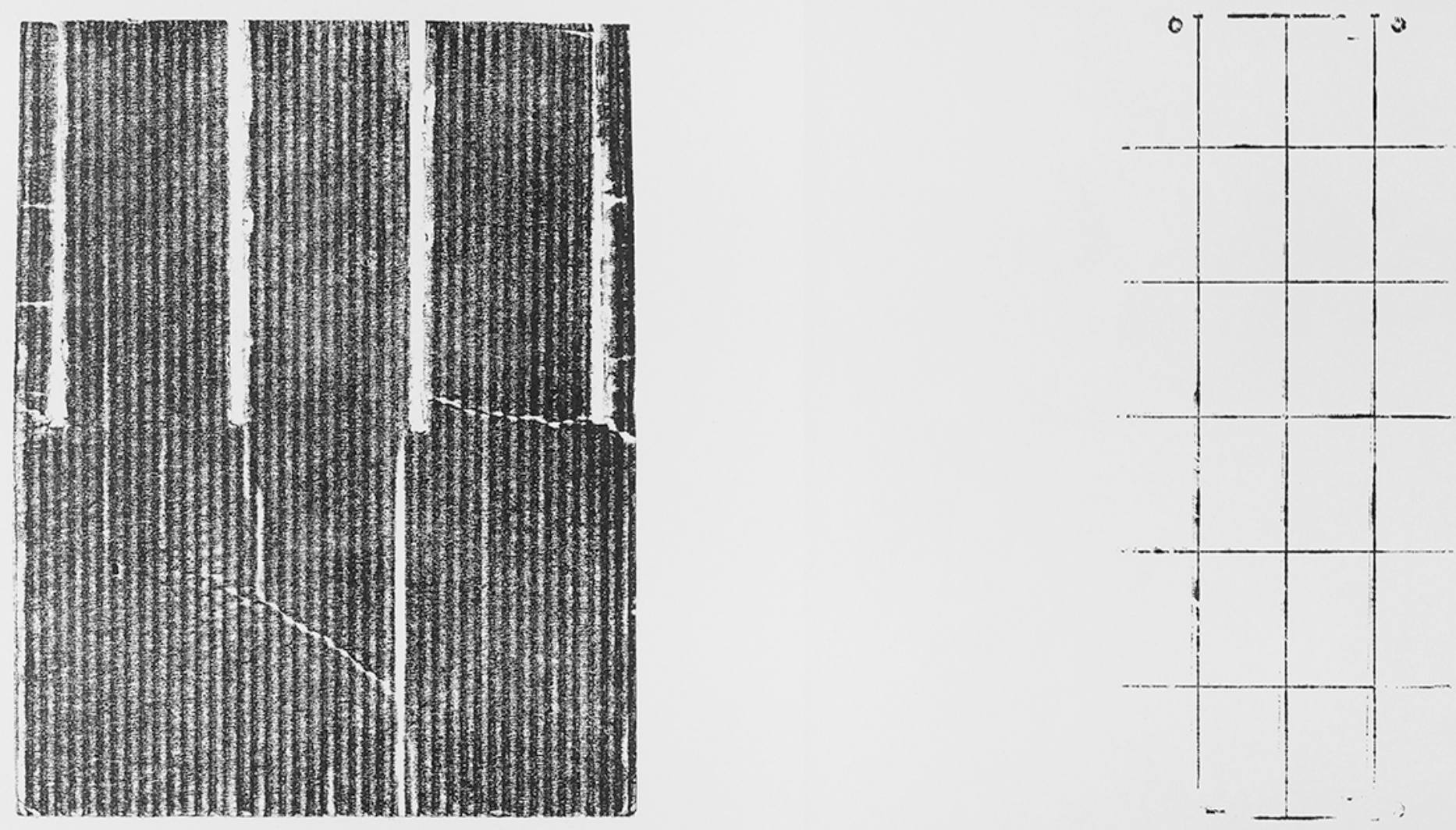


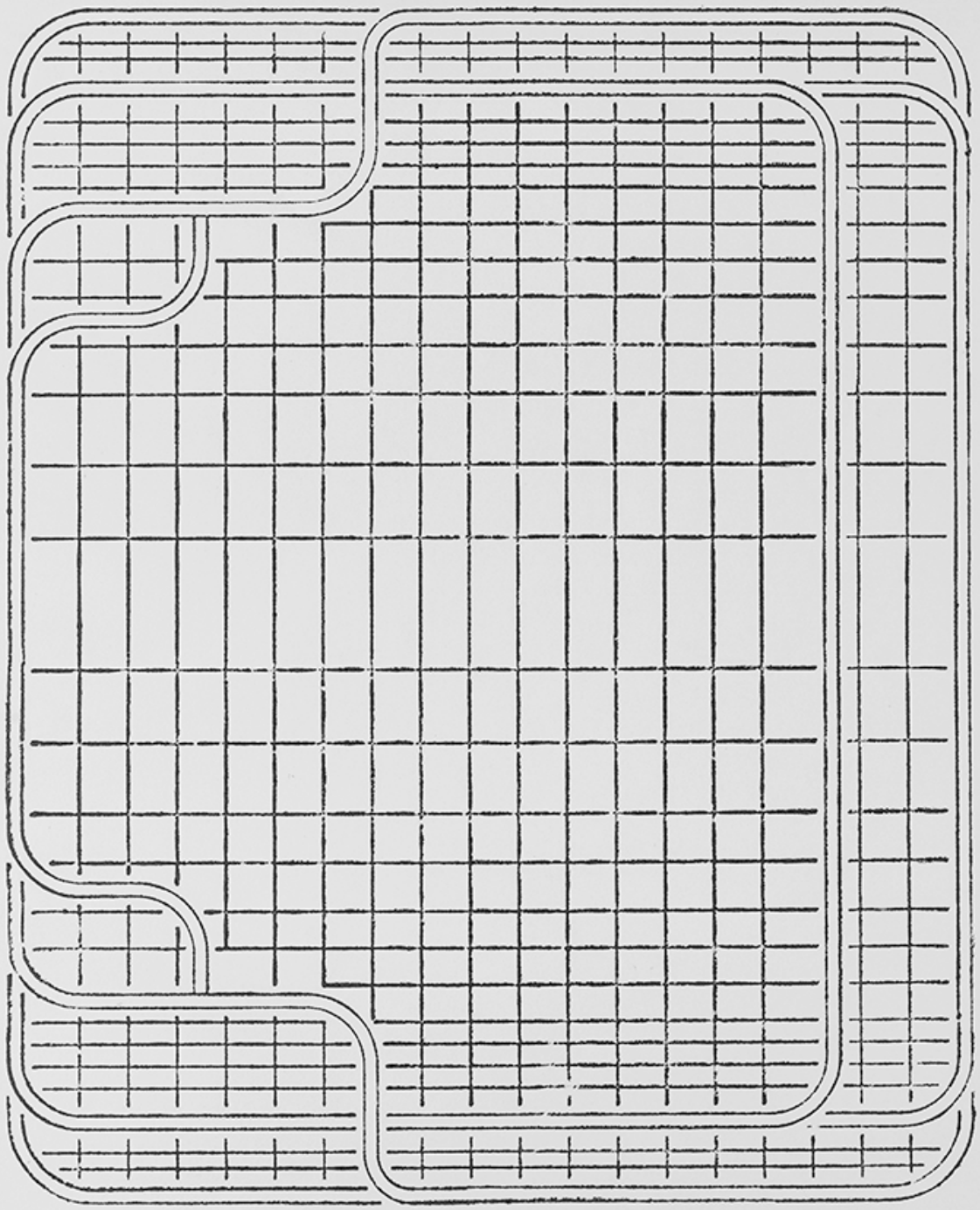



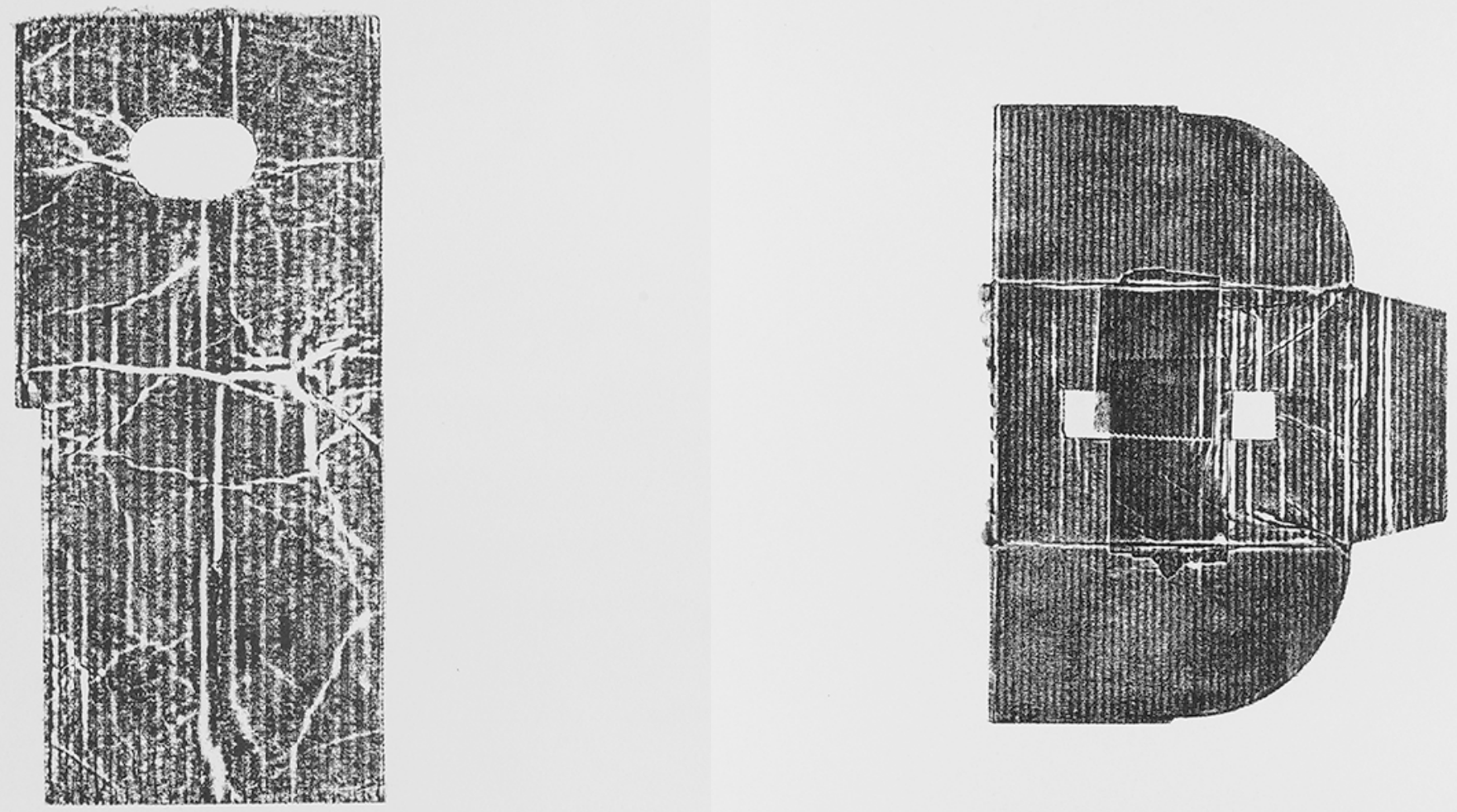


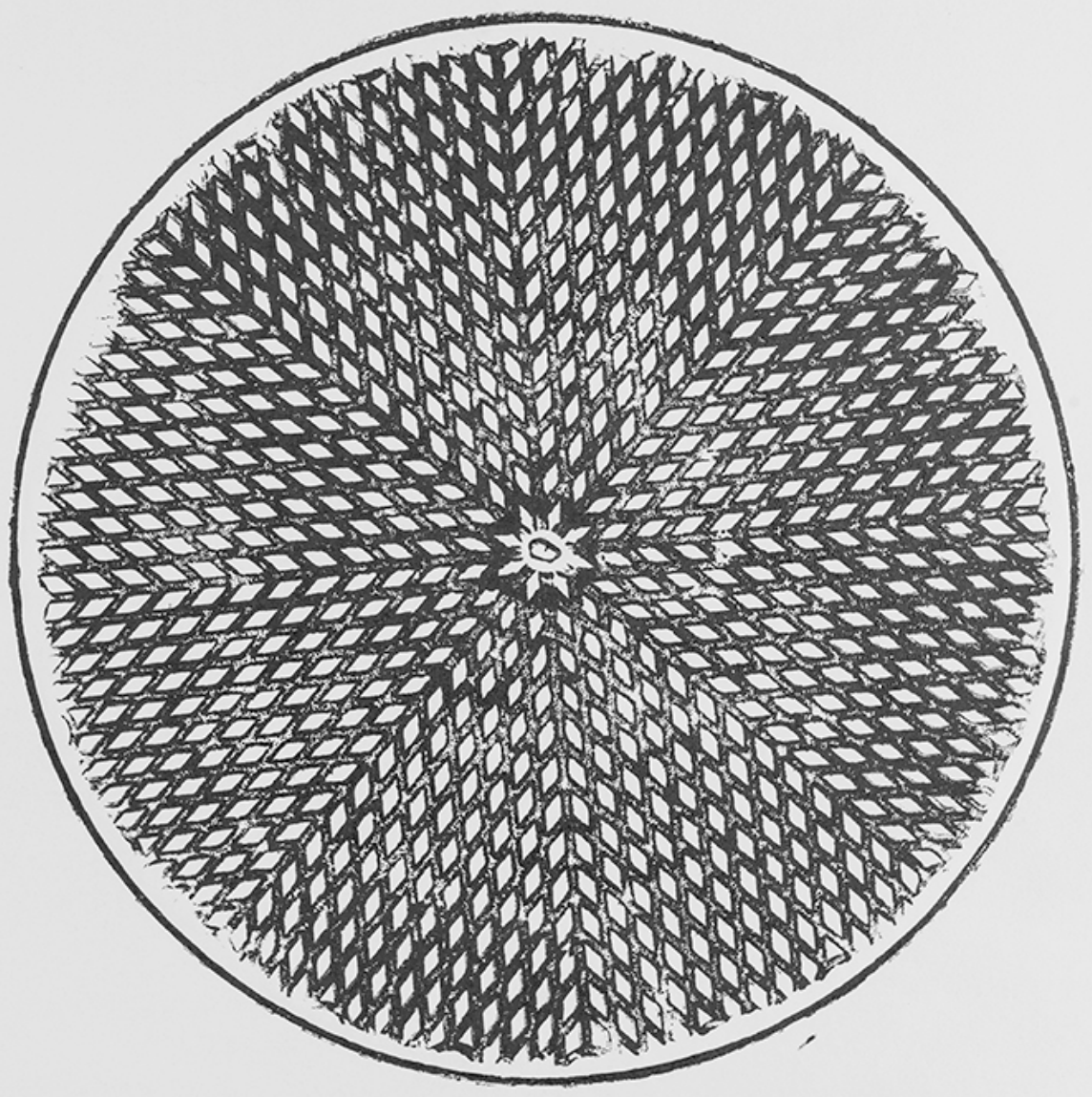




$$
\square
$$



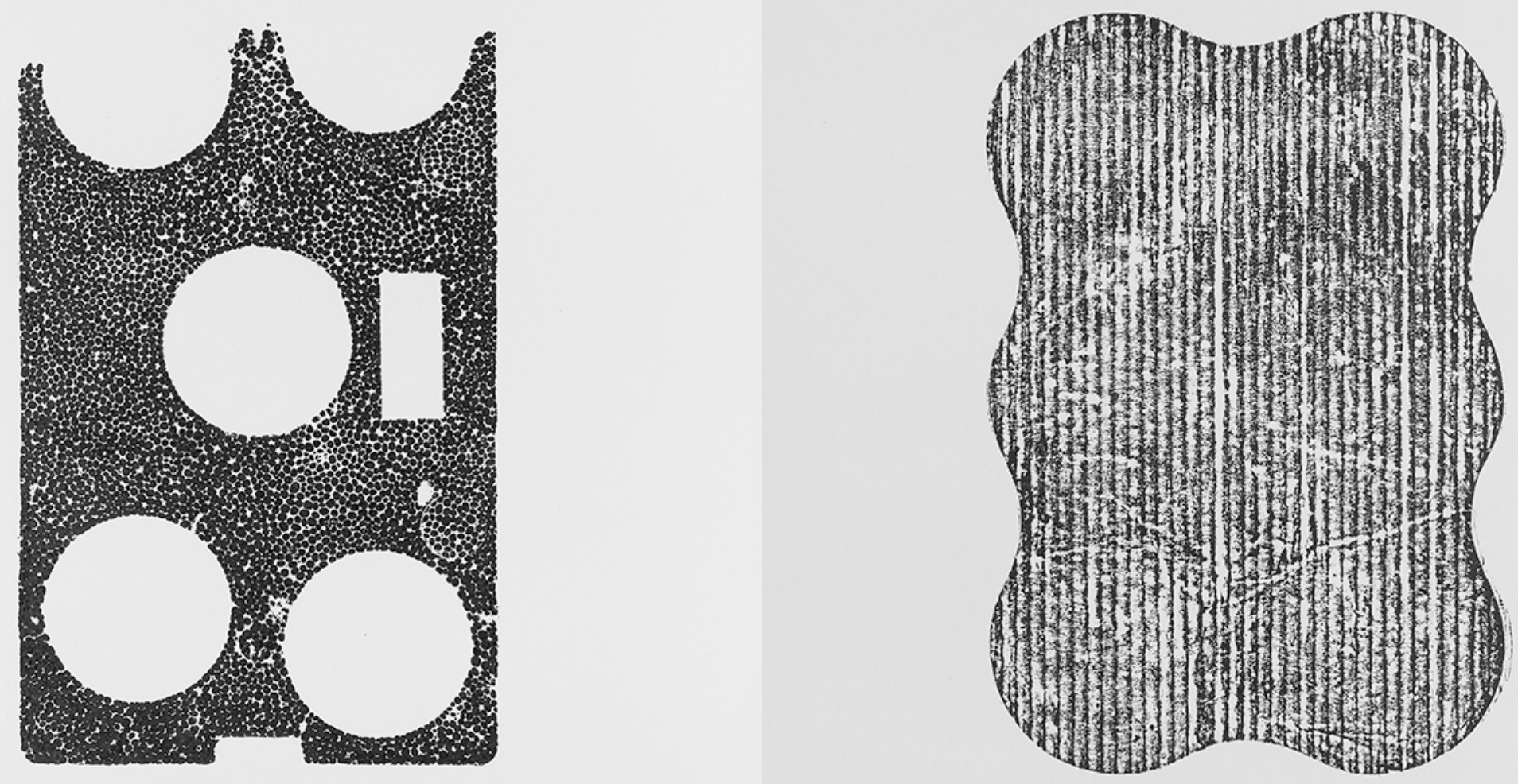


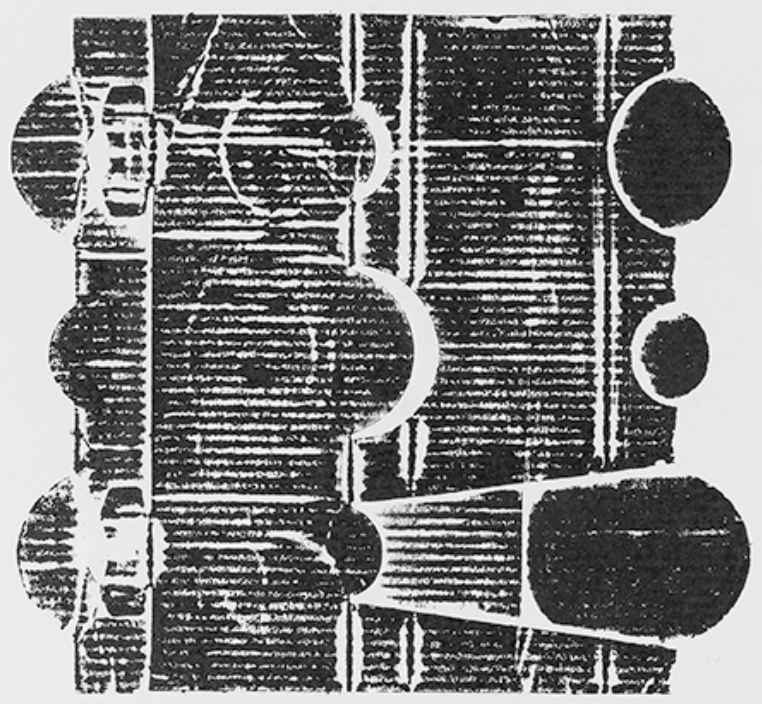




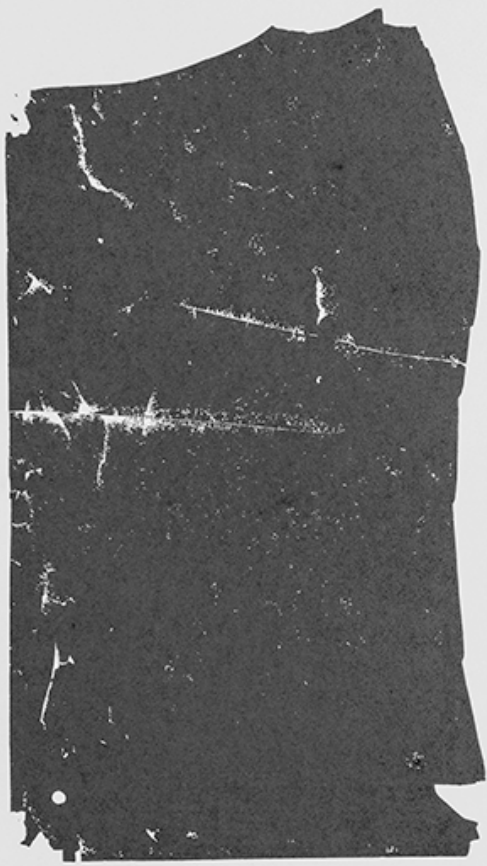




$$
=\theta
$$




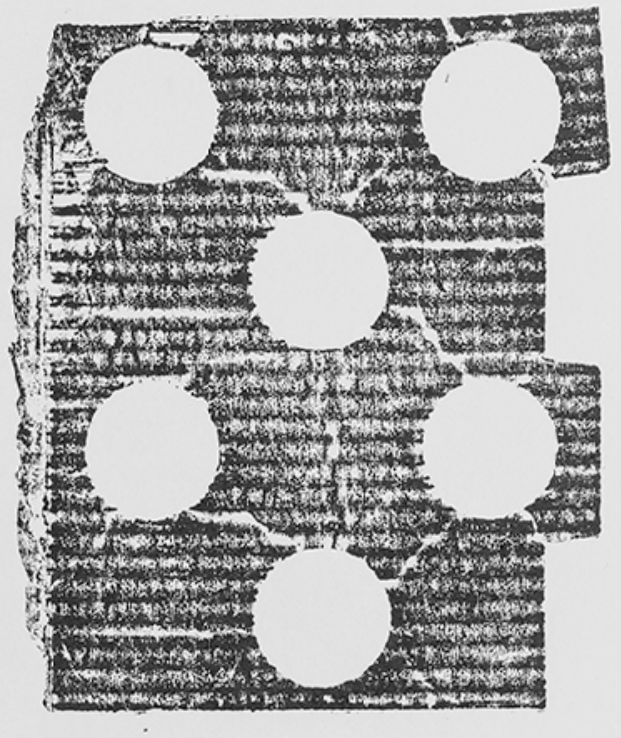




$$
1
$$



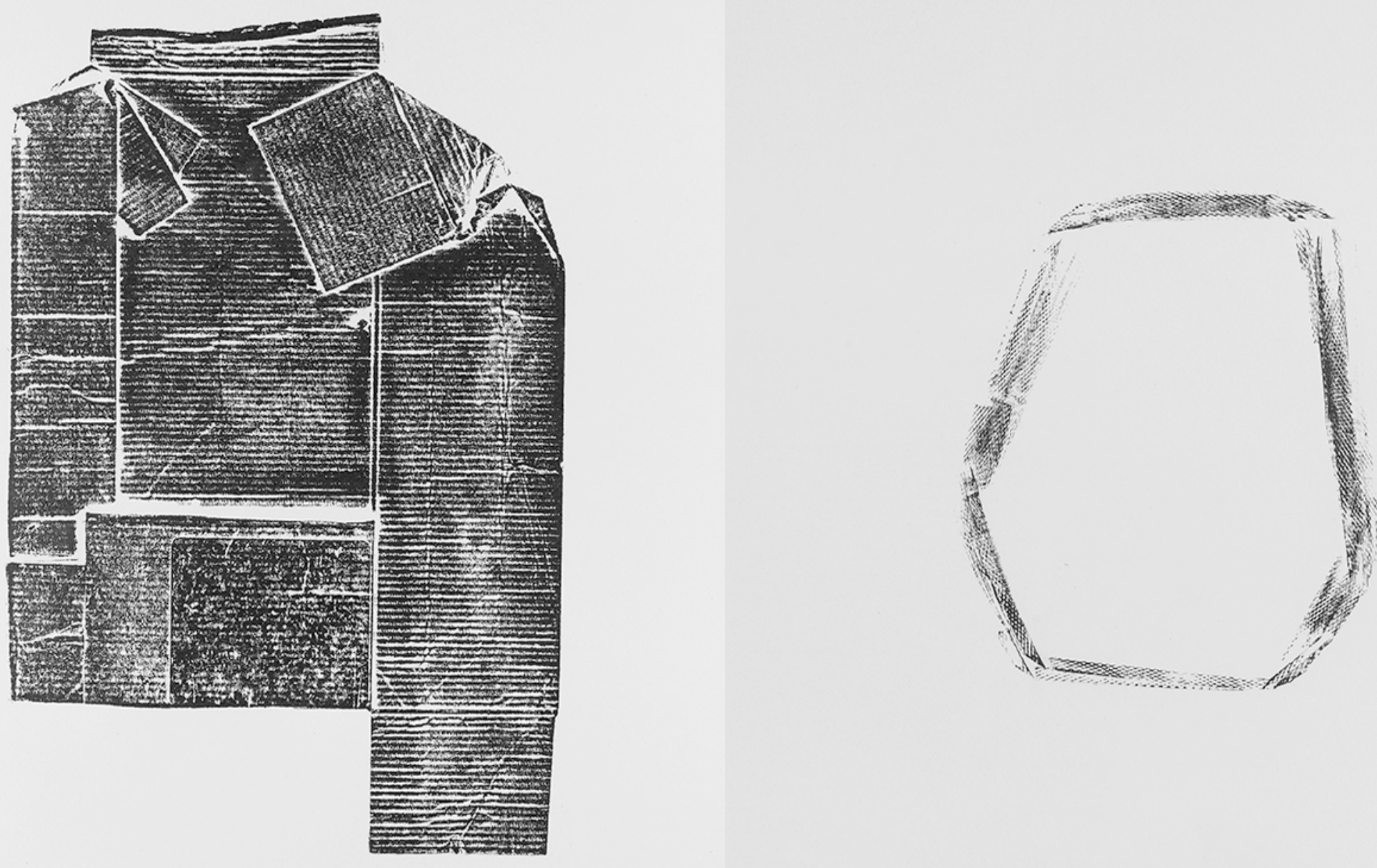

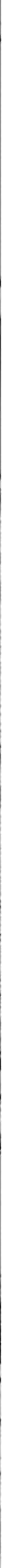


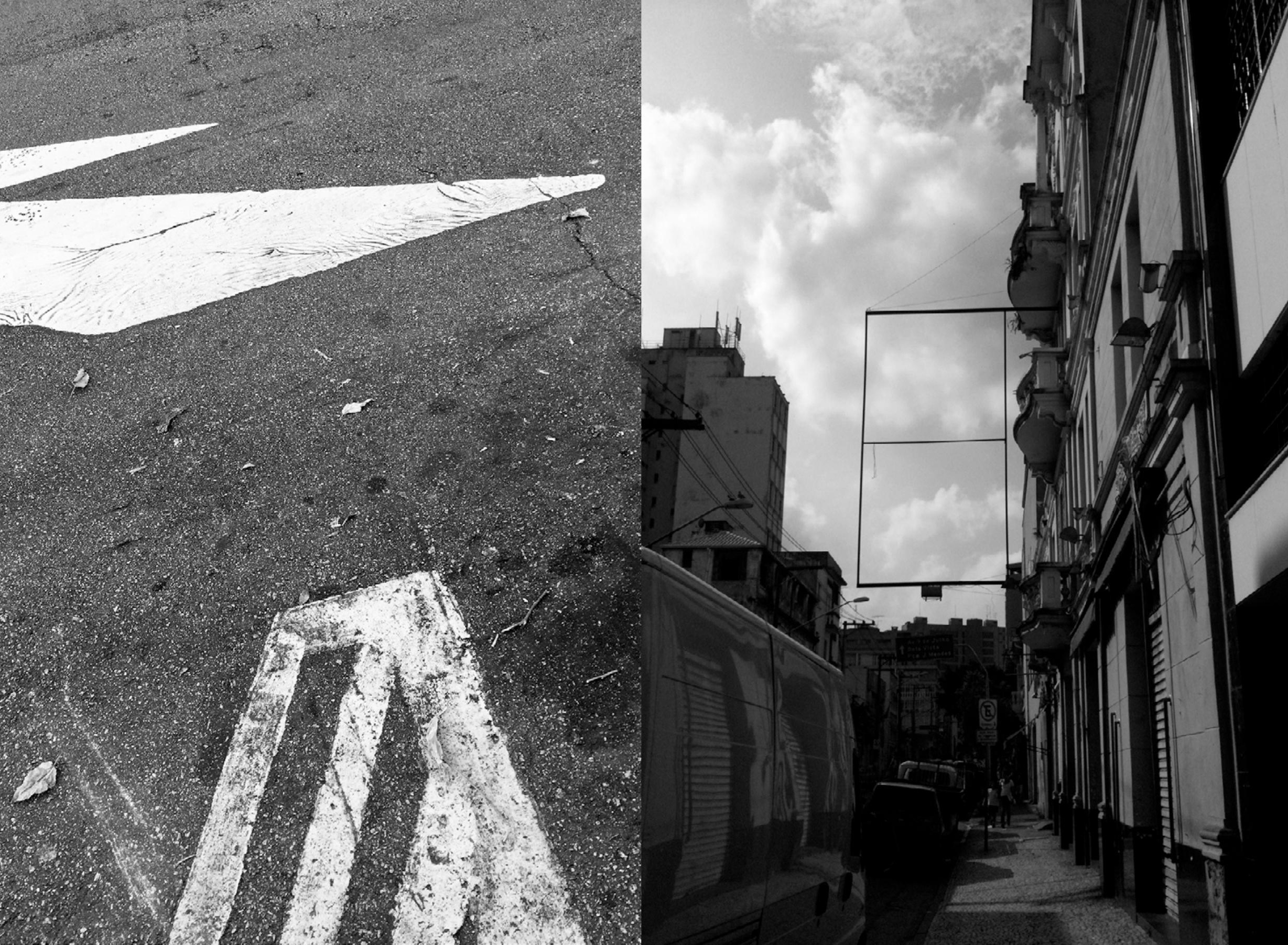




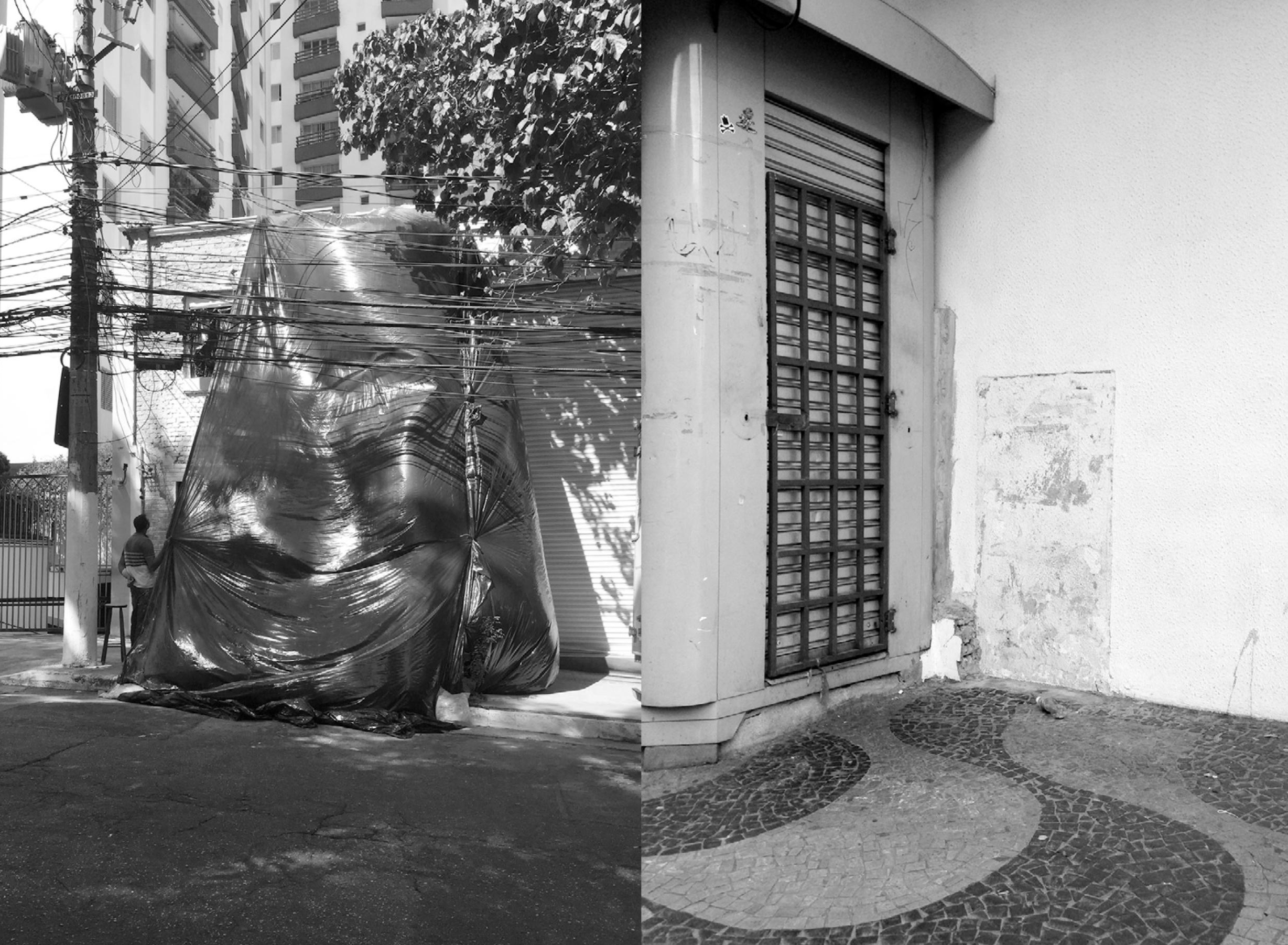





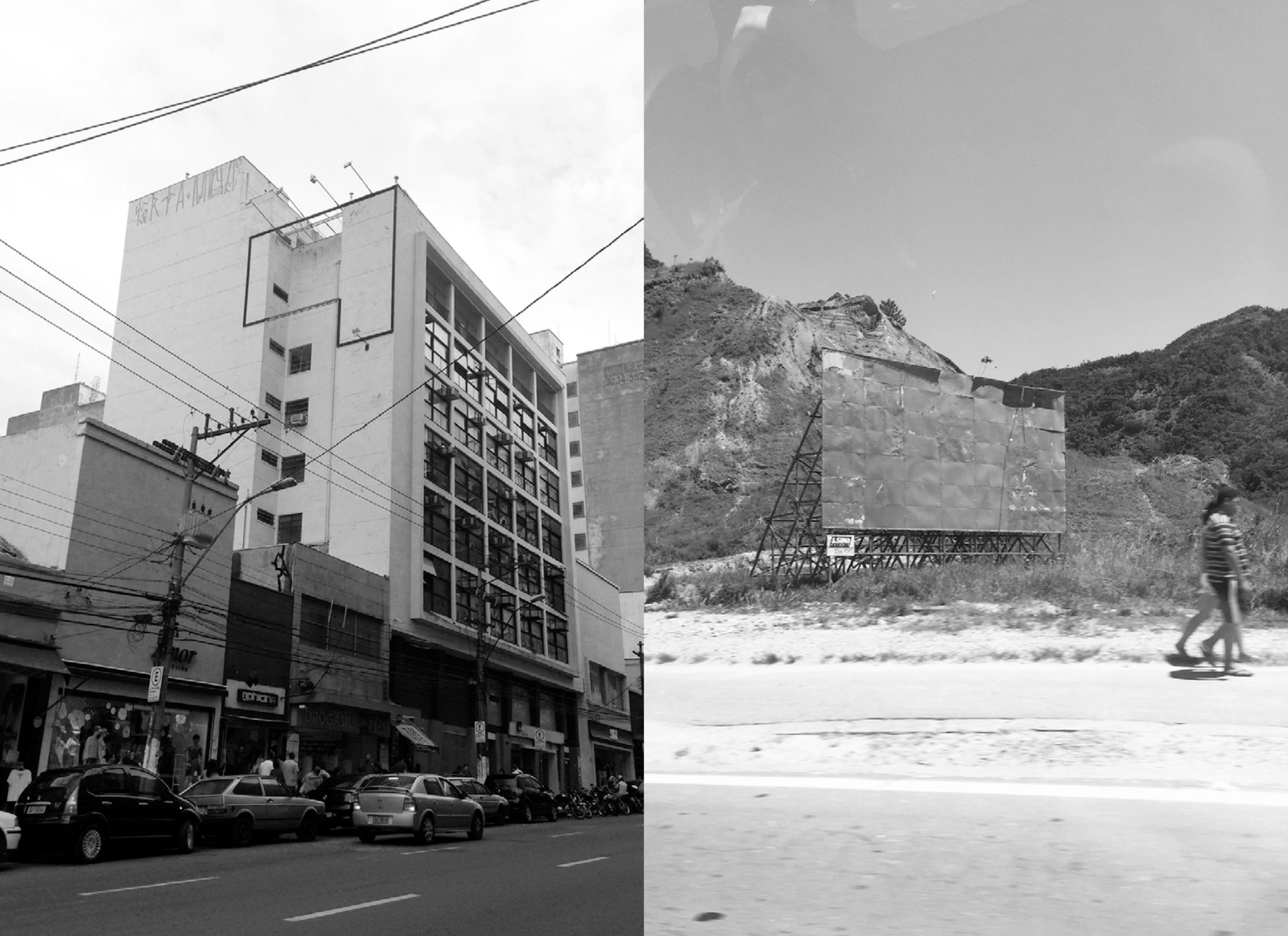




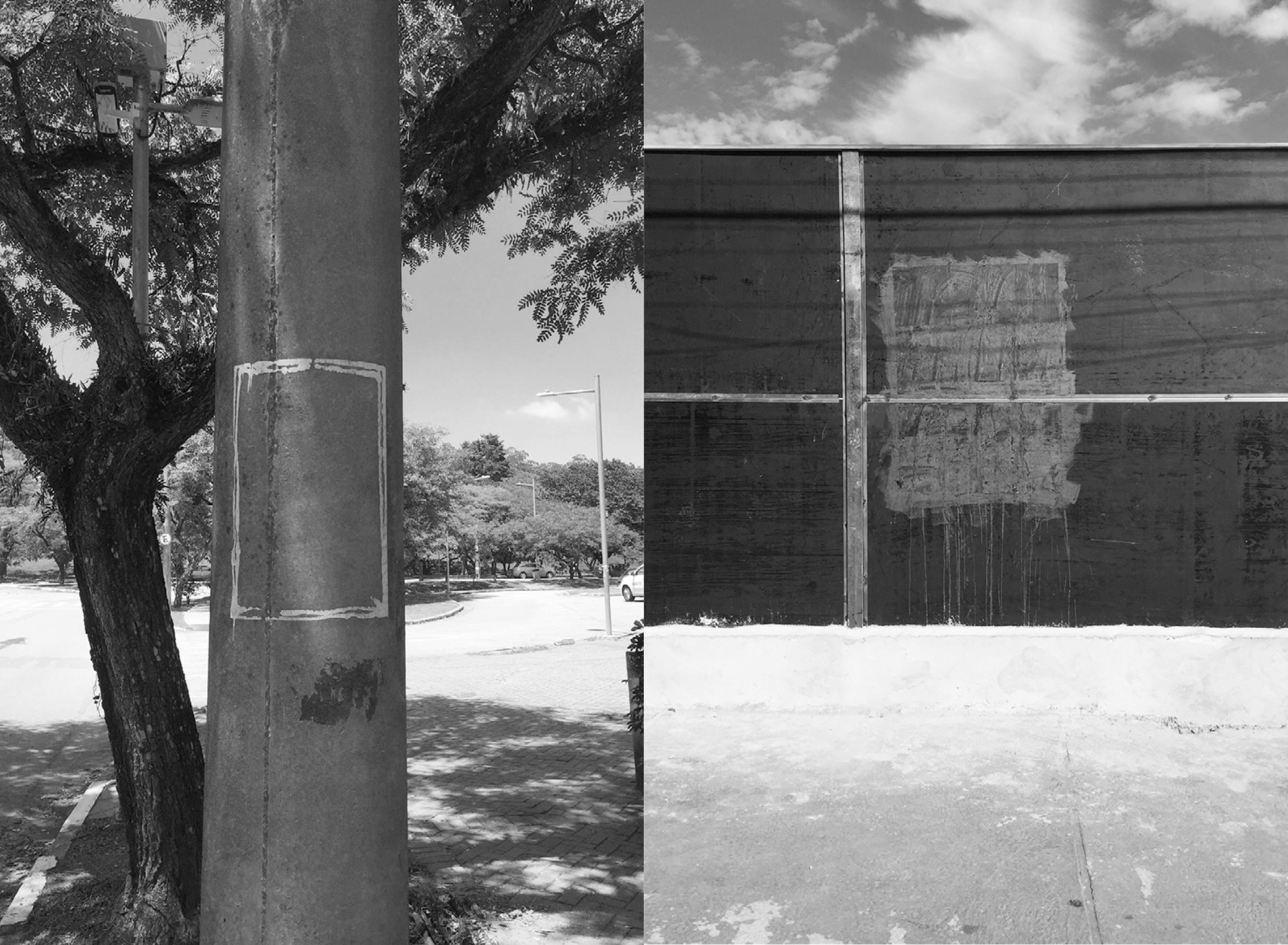




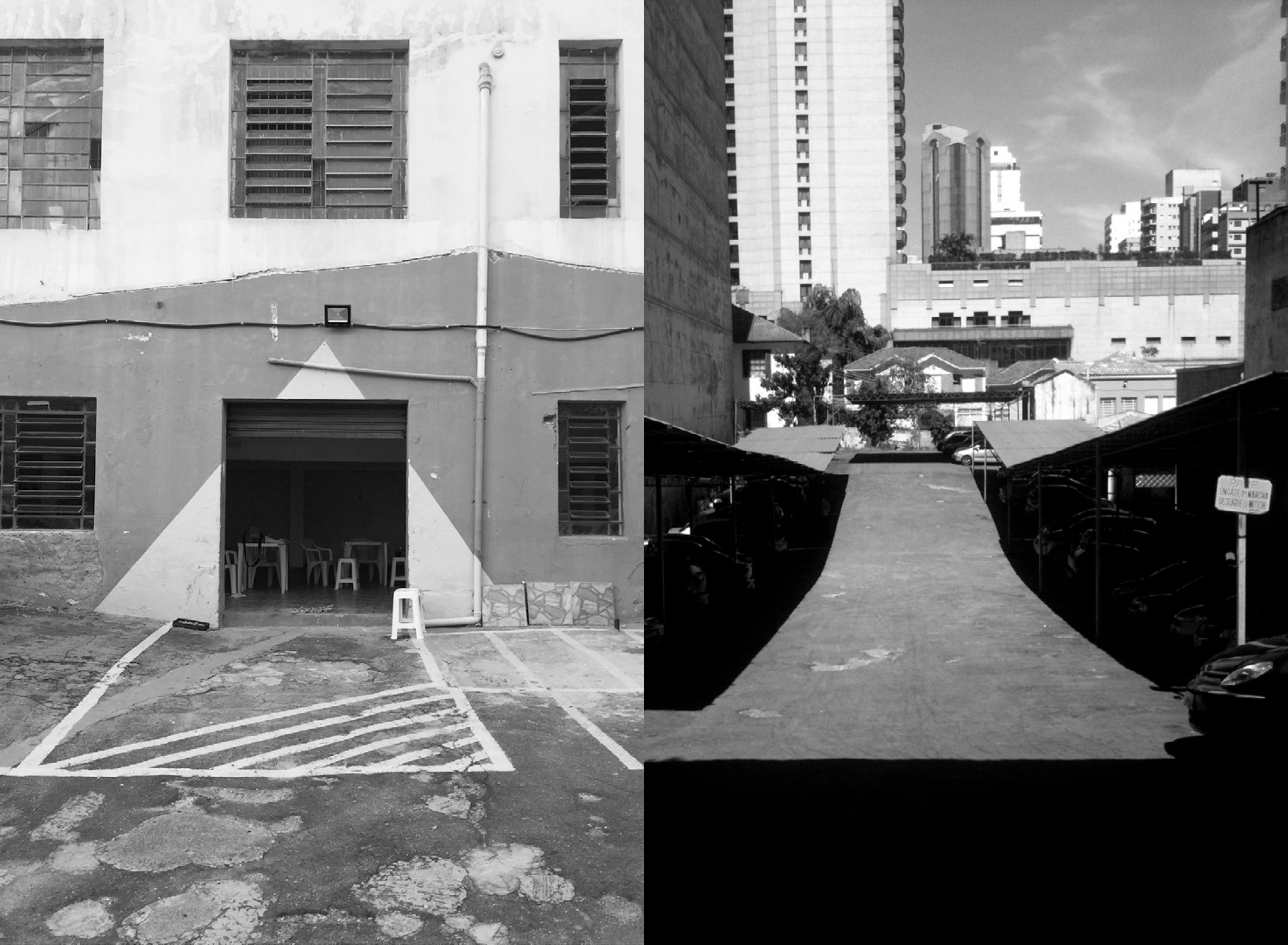



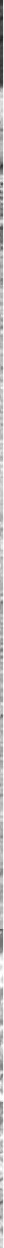

1
1

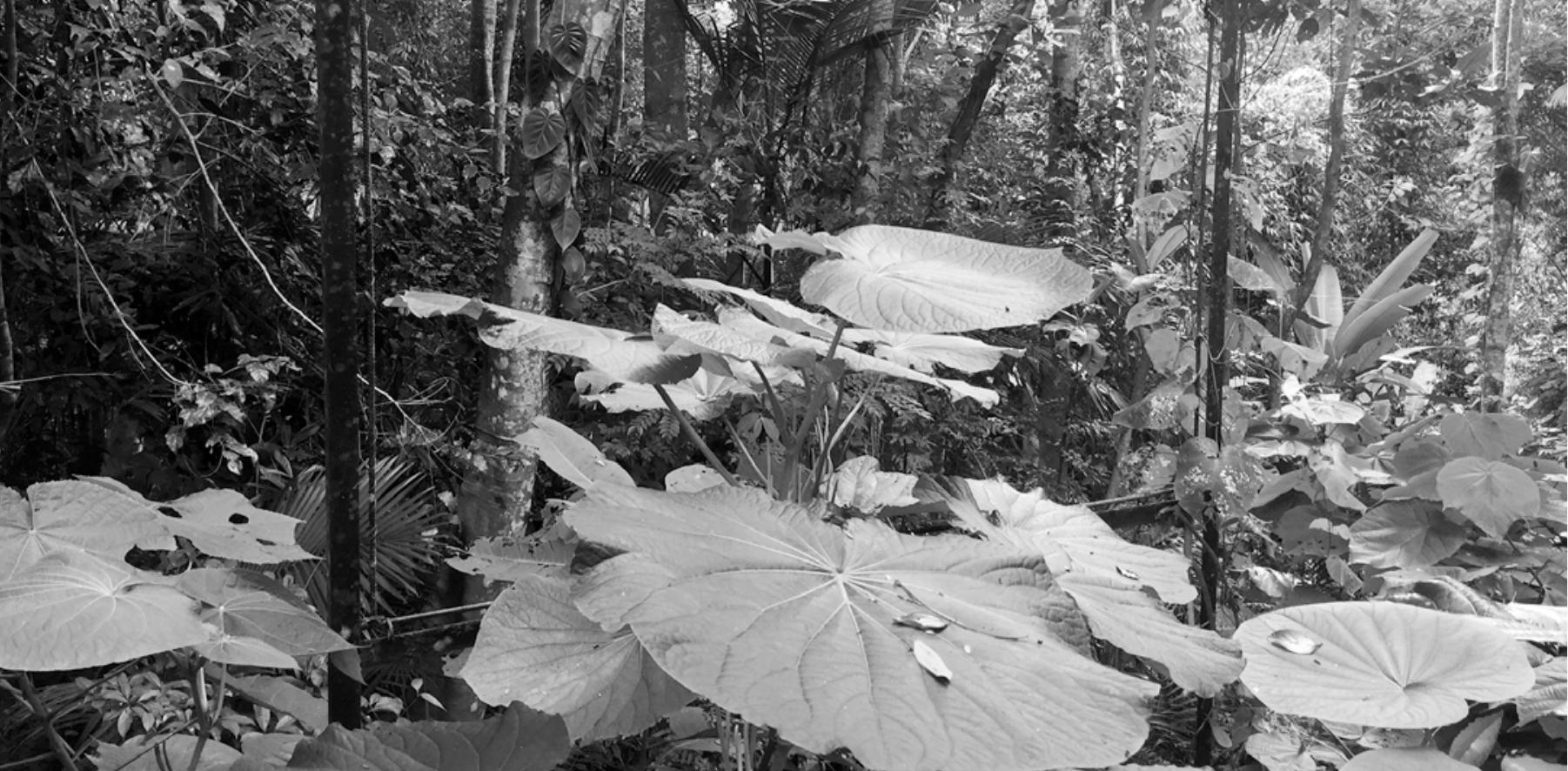




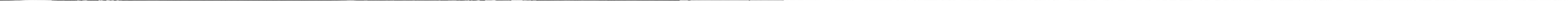




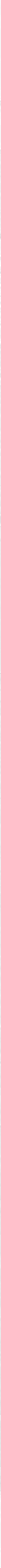




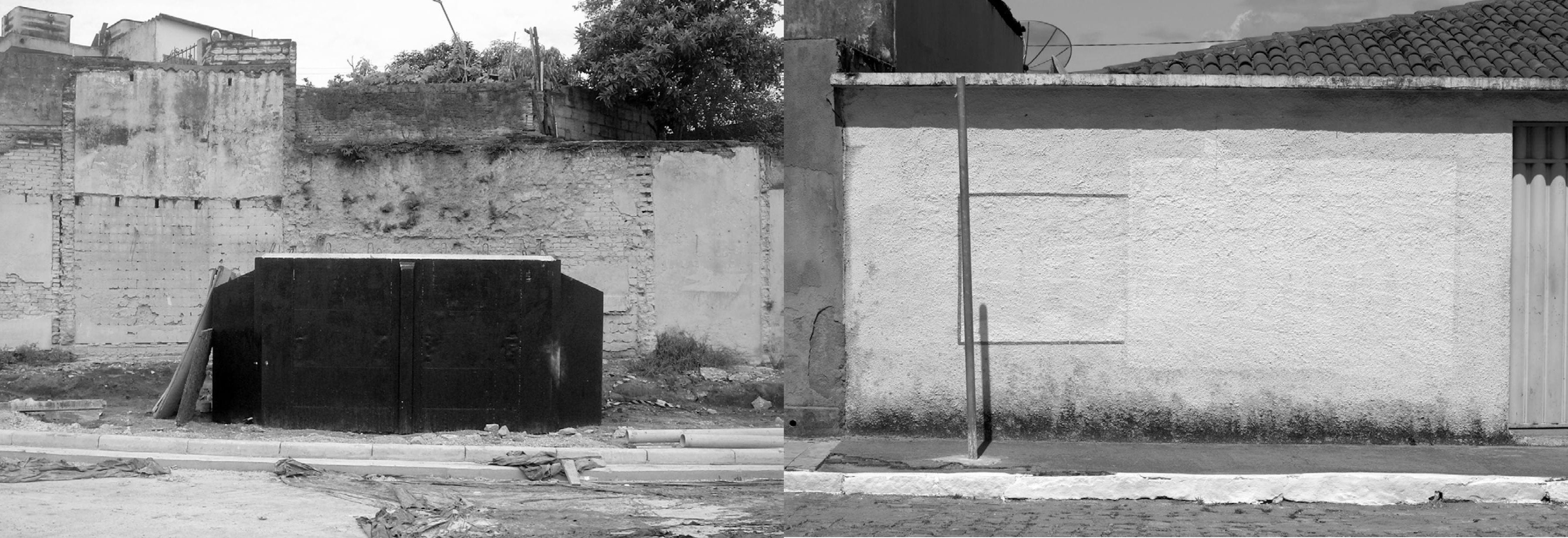


and

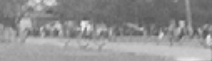

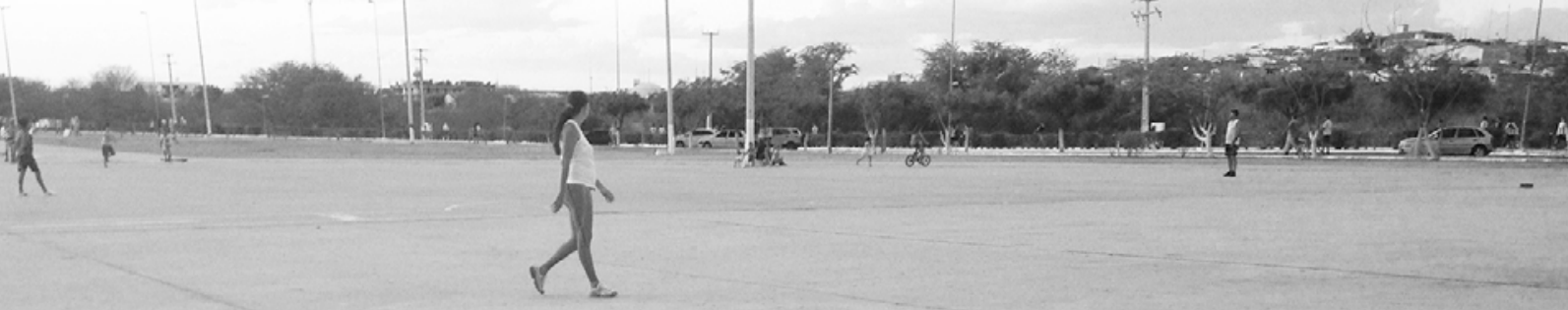

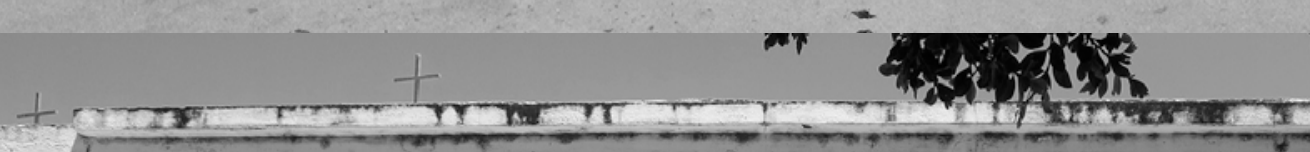

,
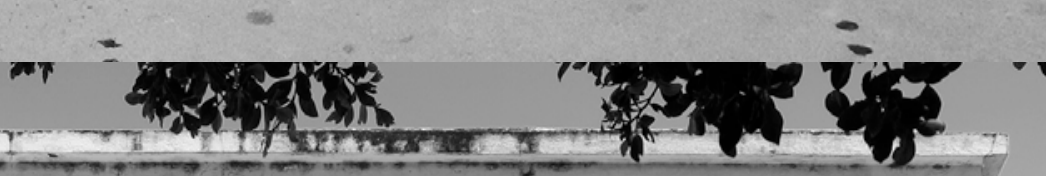

ह.

tation

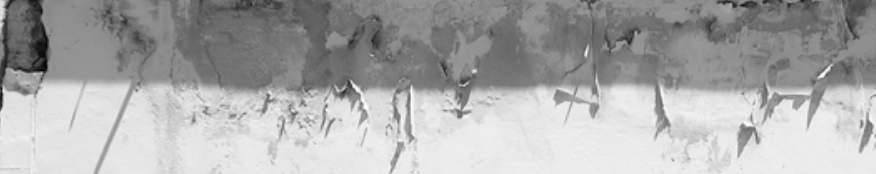
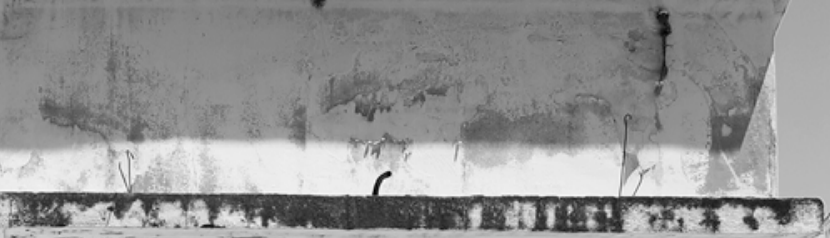

0
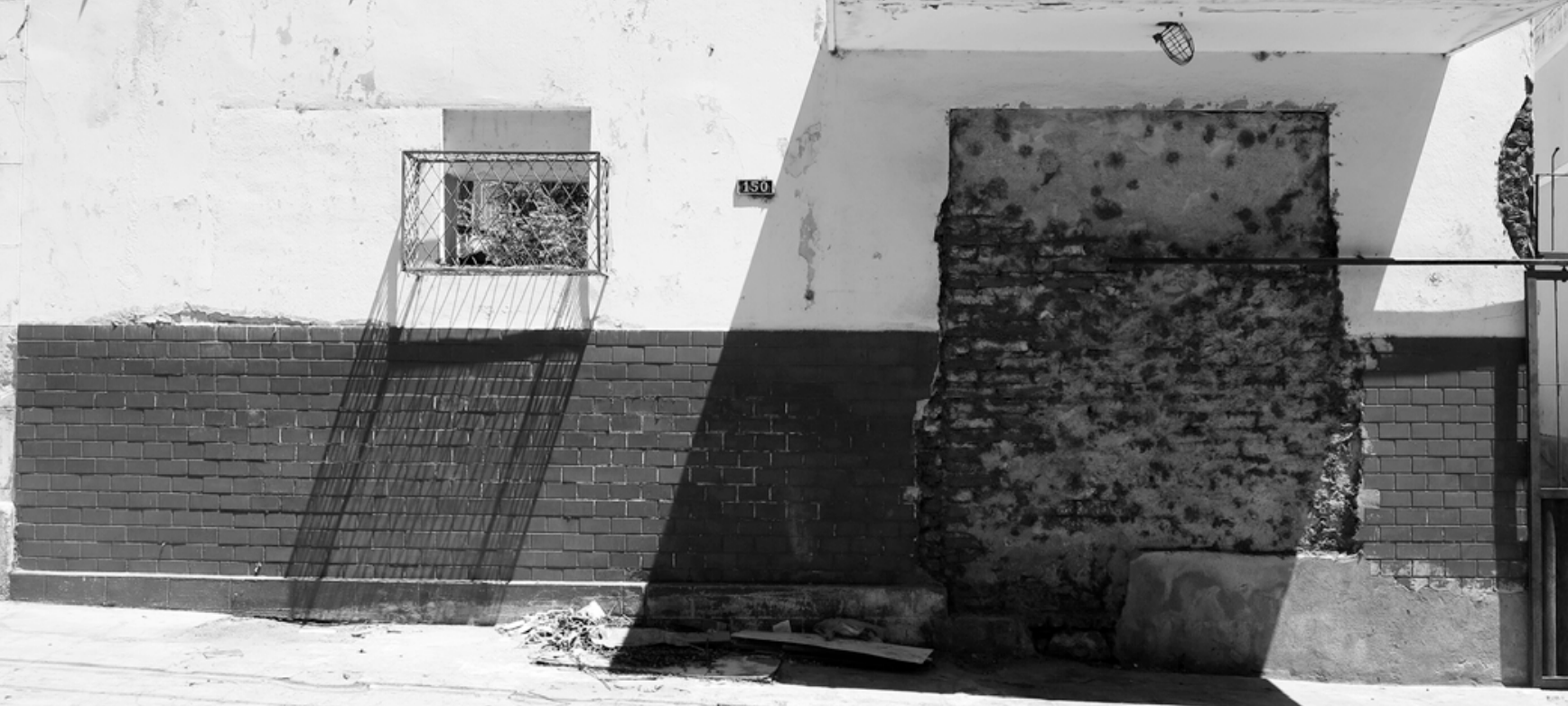

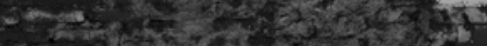

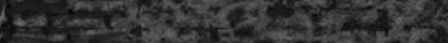

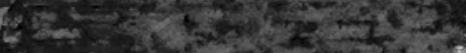

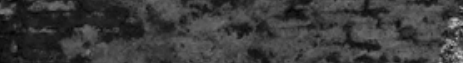

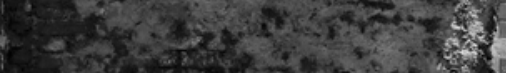

2.M.

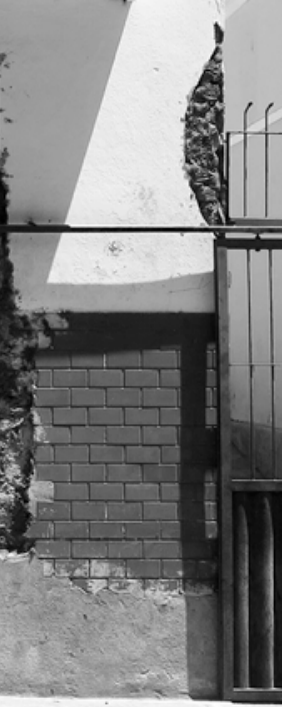

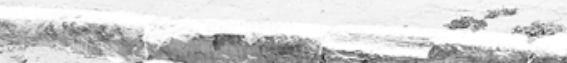




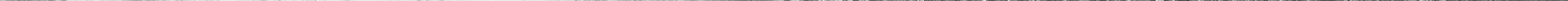



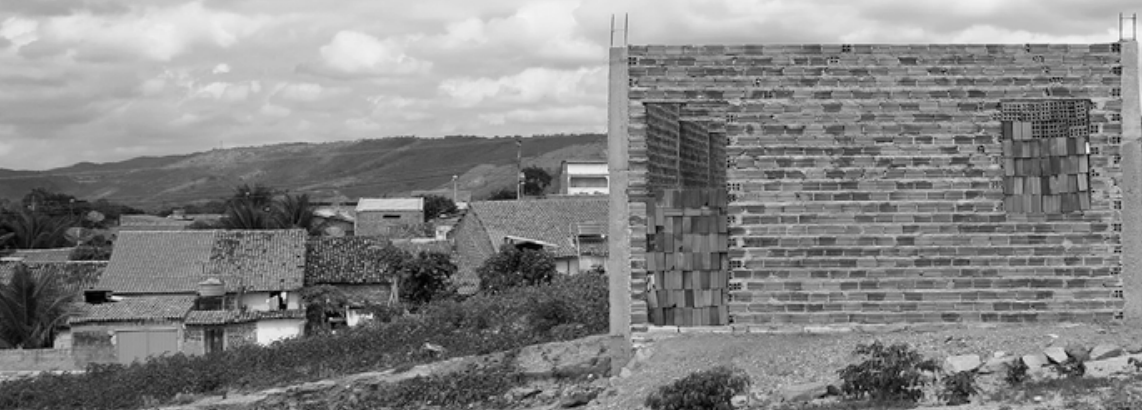

(250)

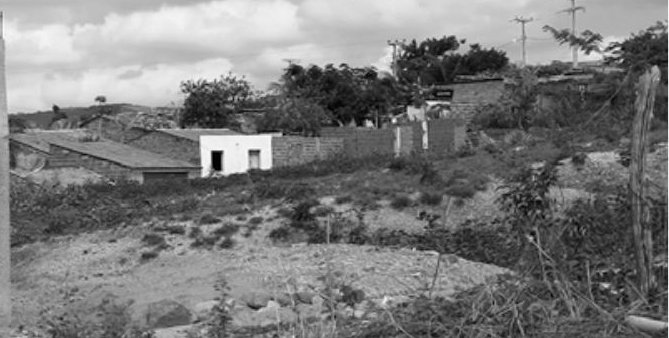

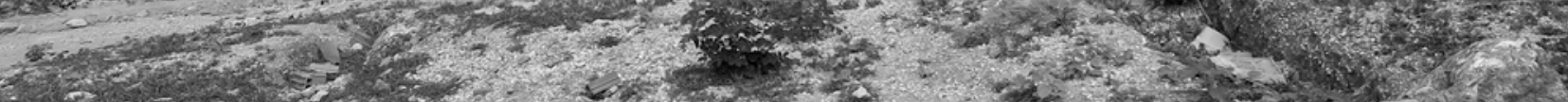

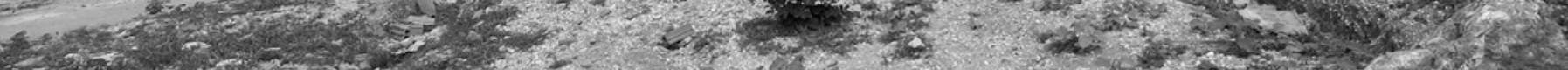

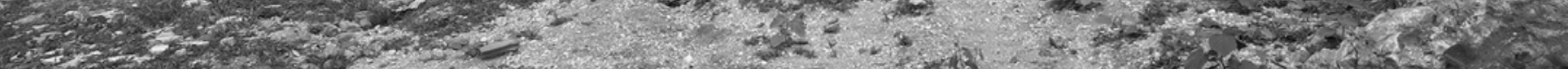
(1) (12)

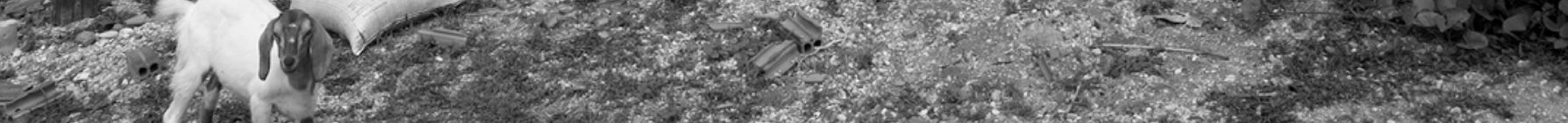

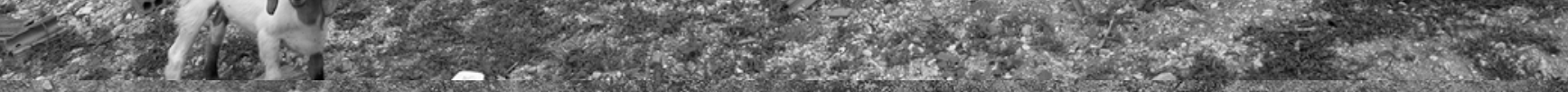

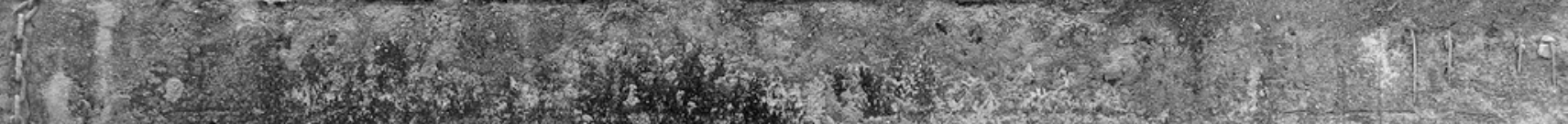
\begin{tabular}{l}
1 \\
\hline
\end{tabular}

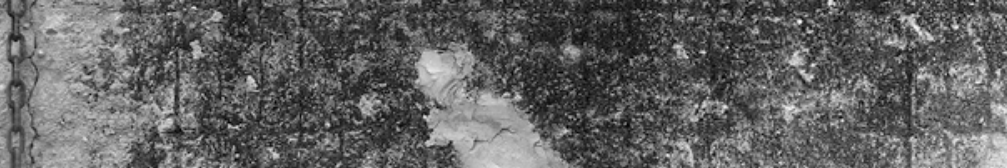

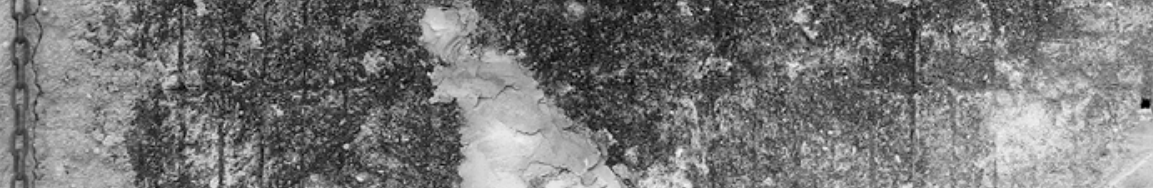
(1)

19.

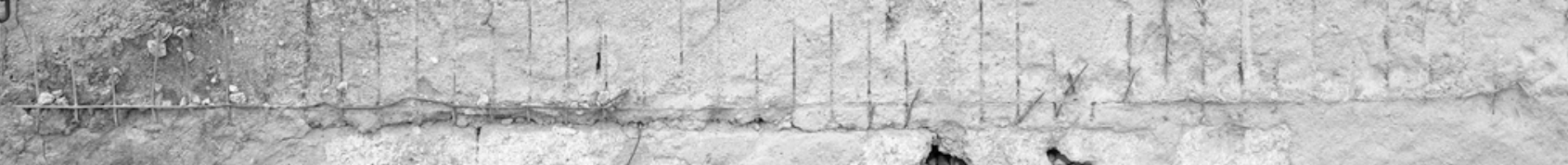




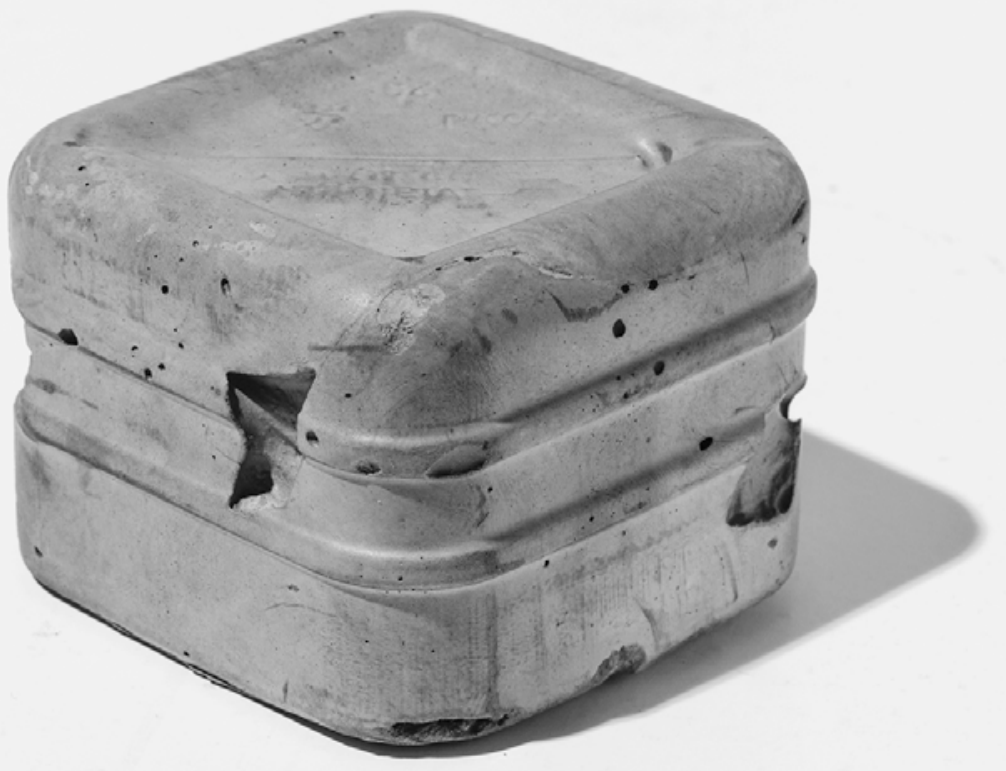





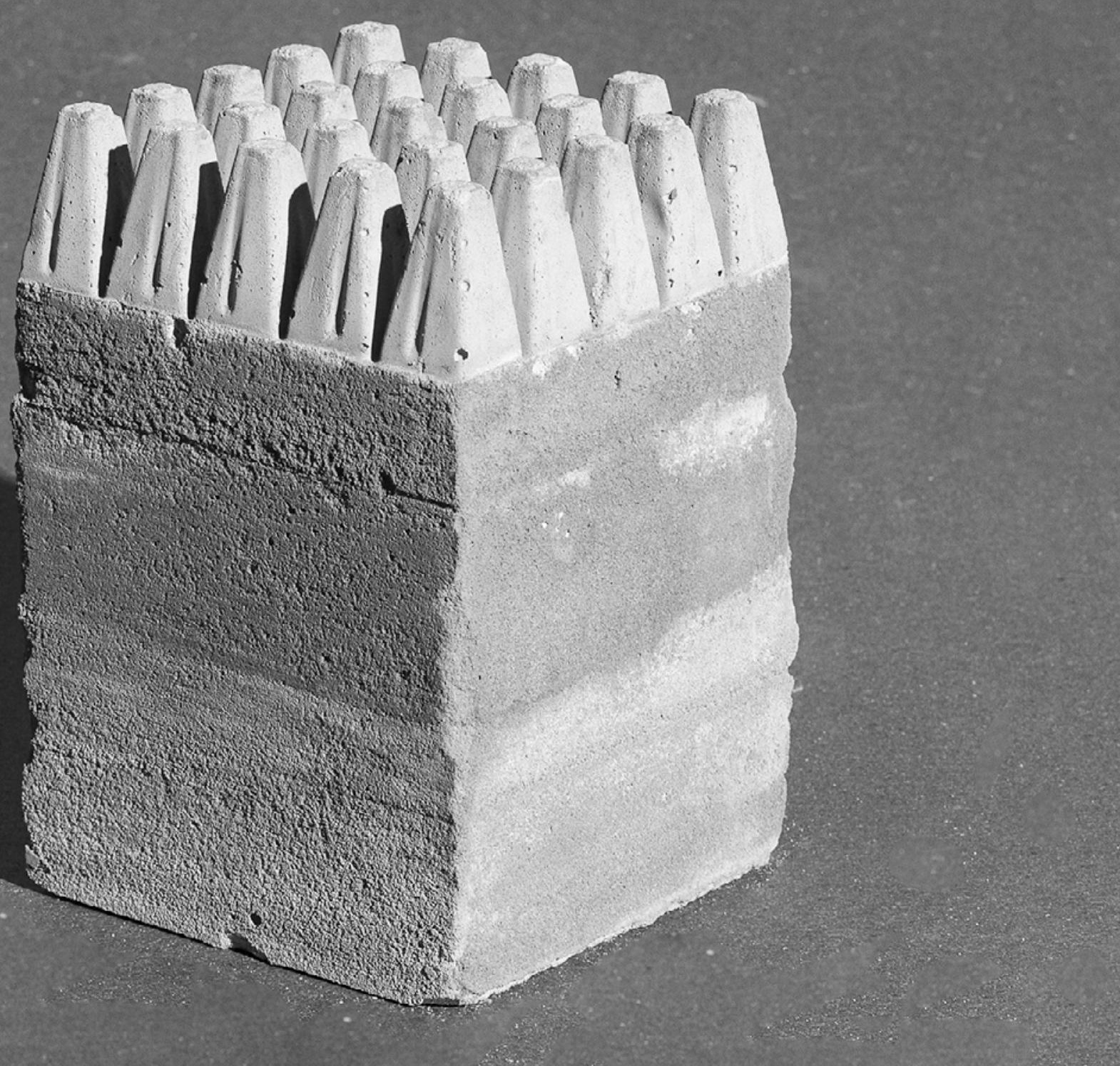




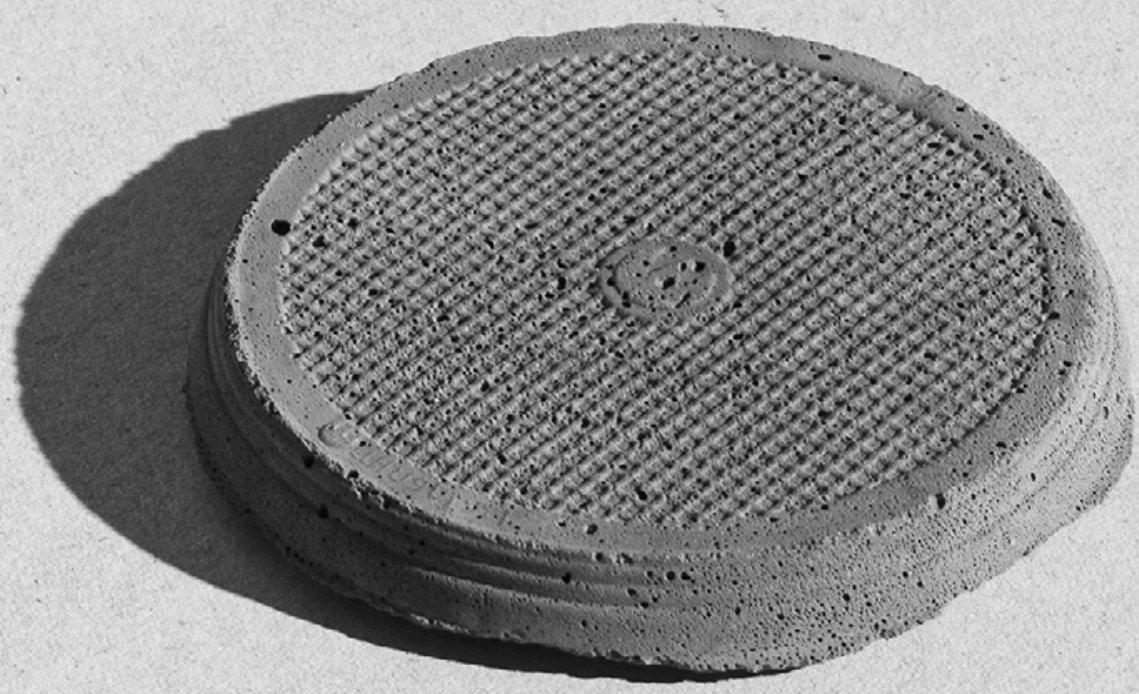




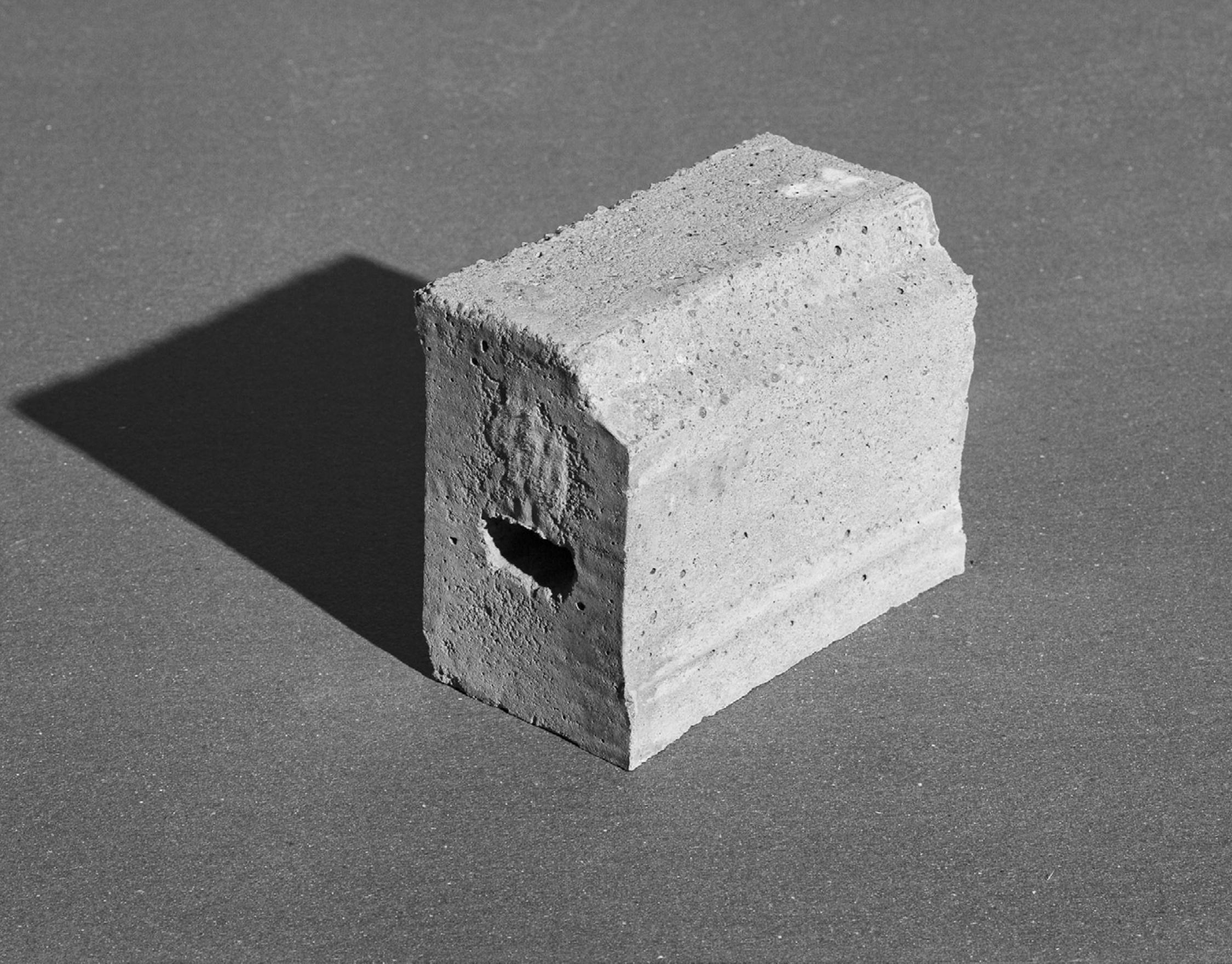




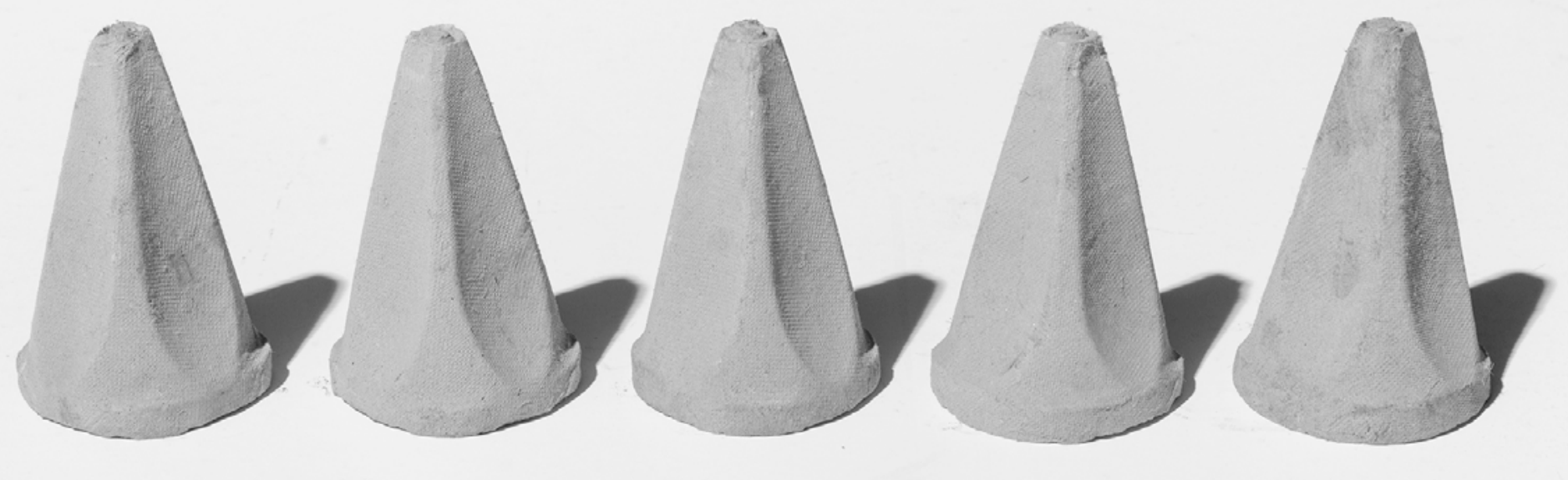




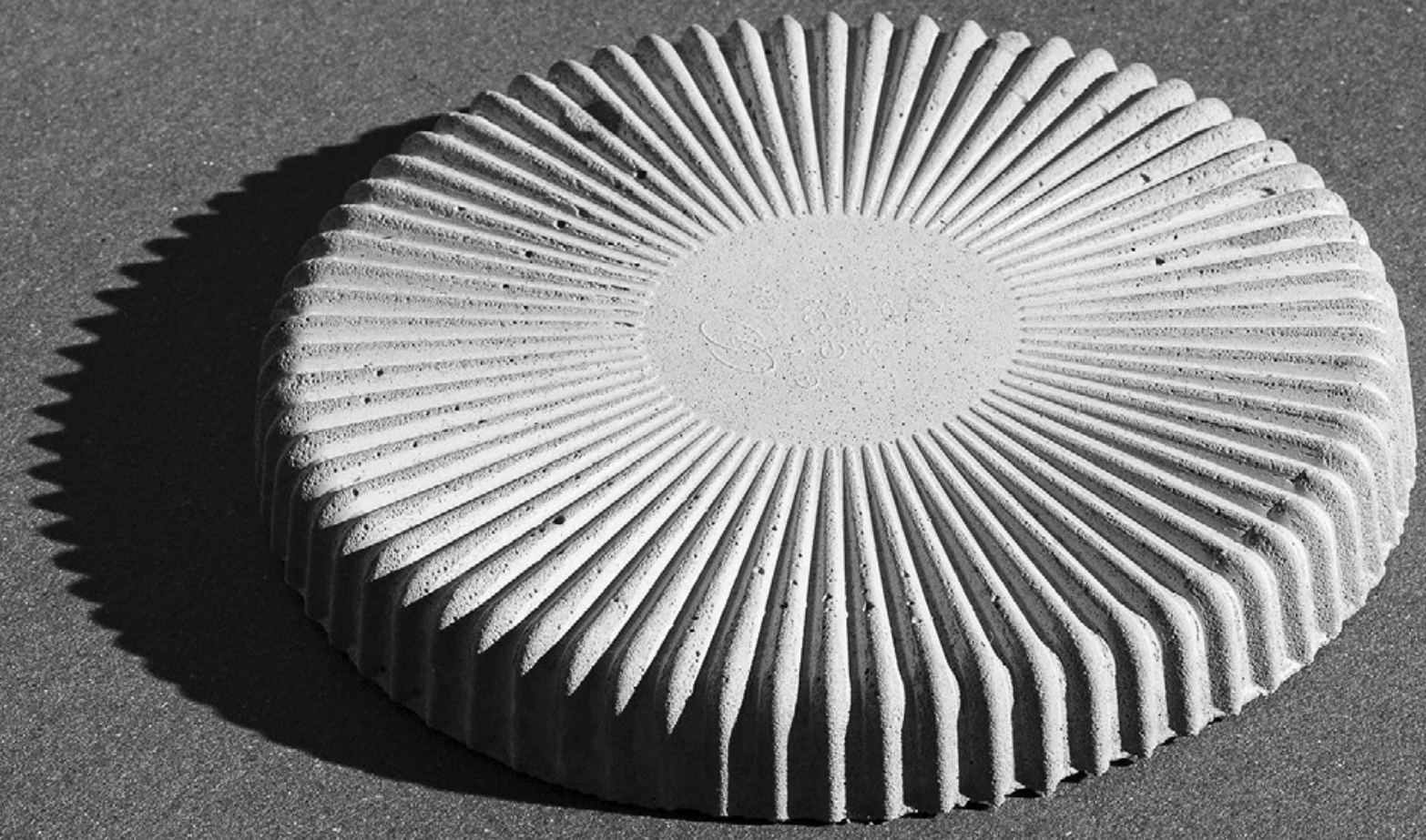




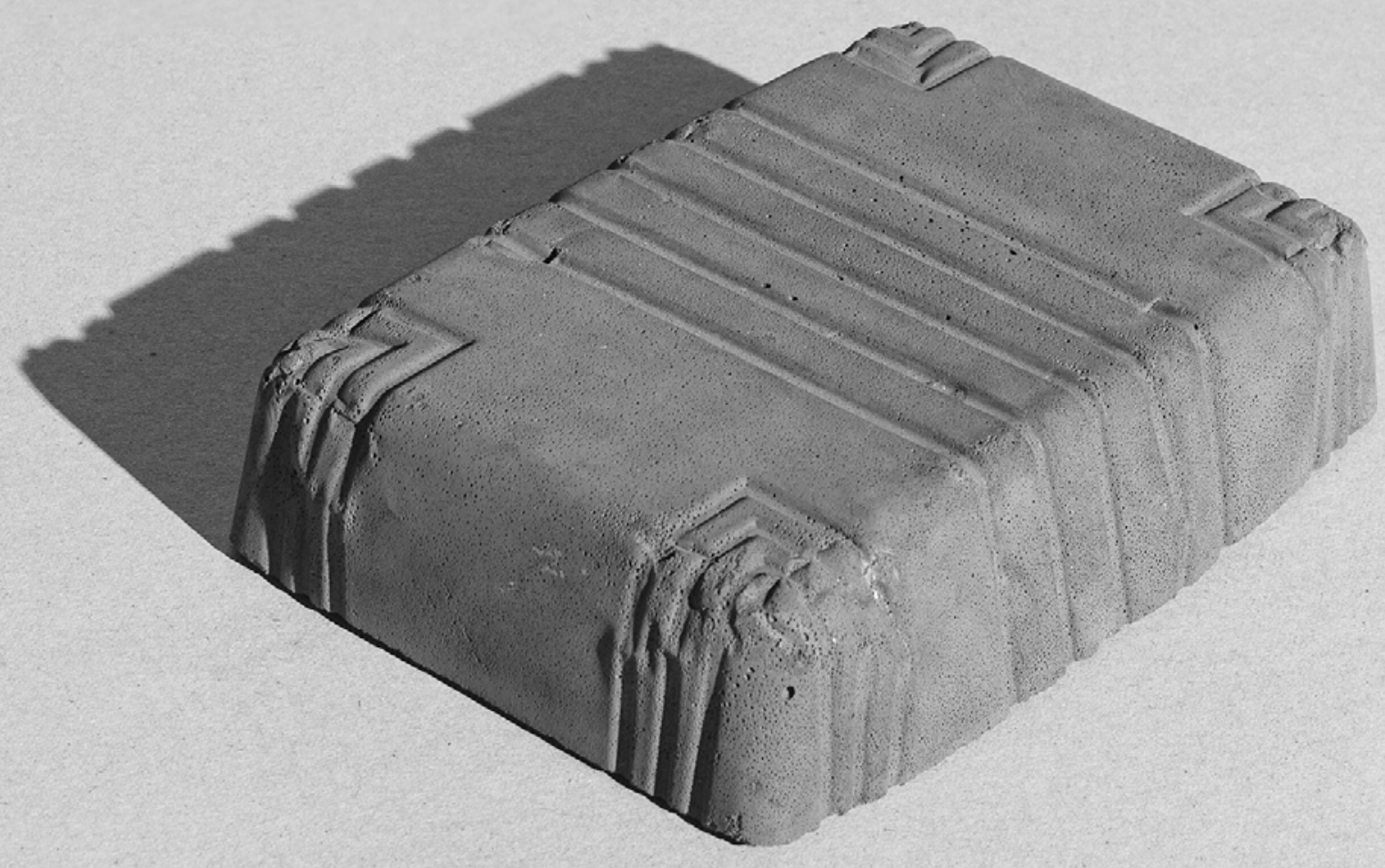




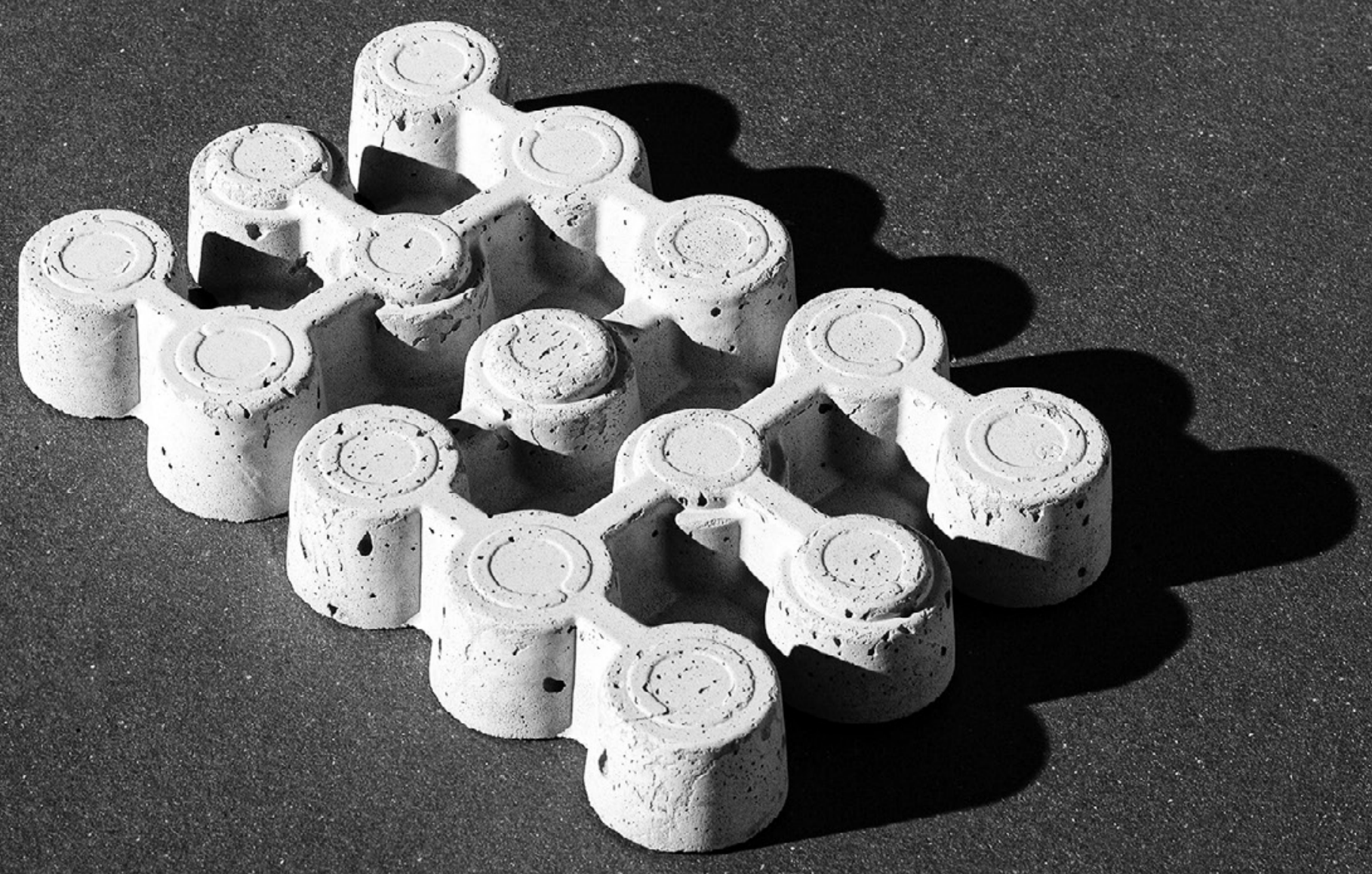




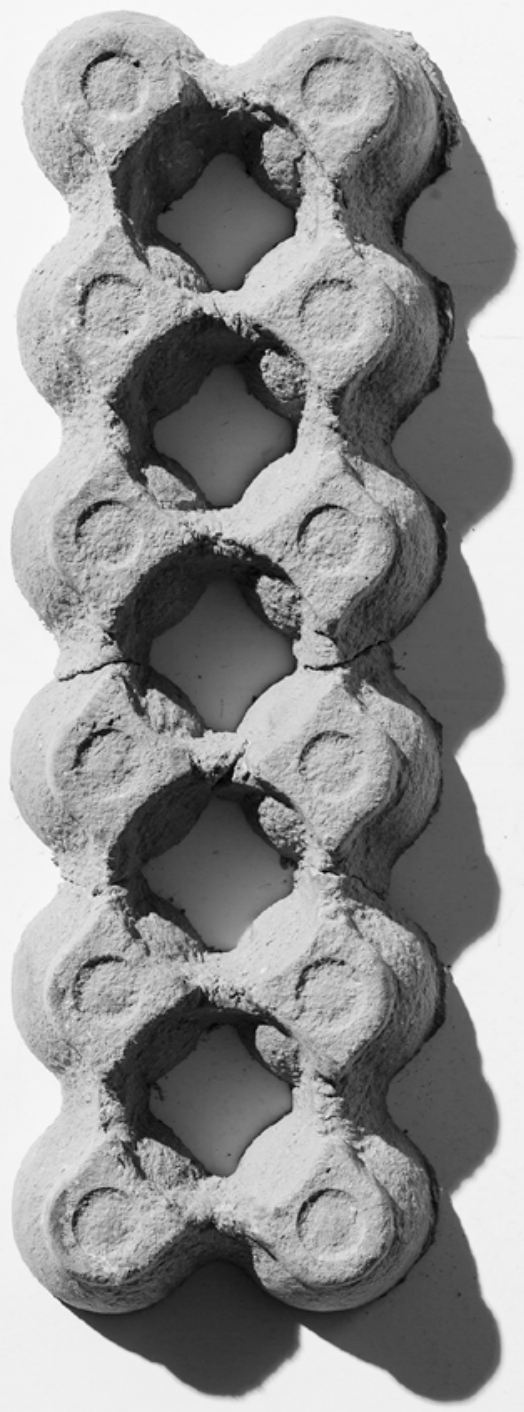




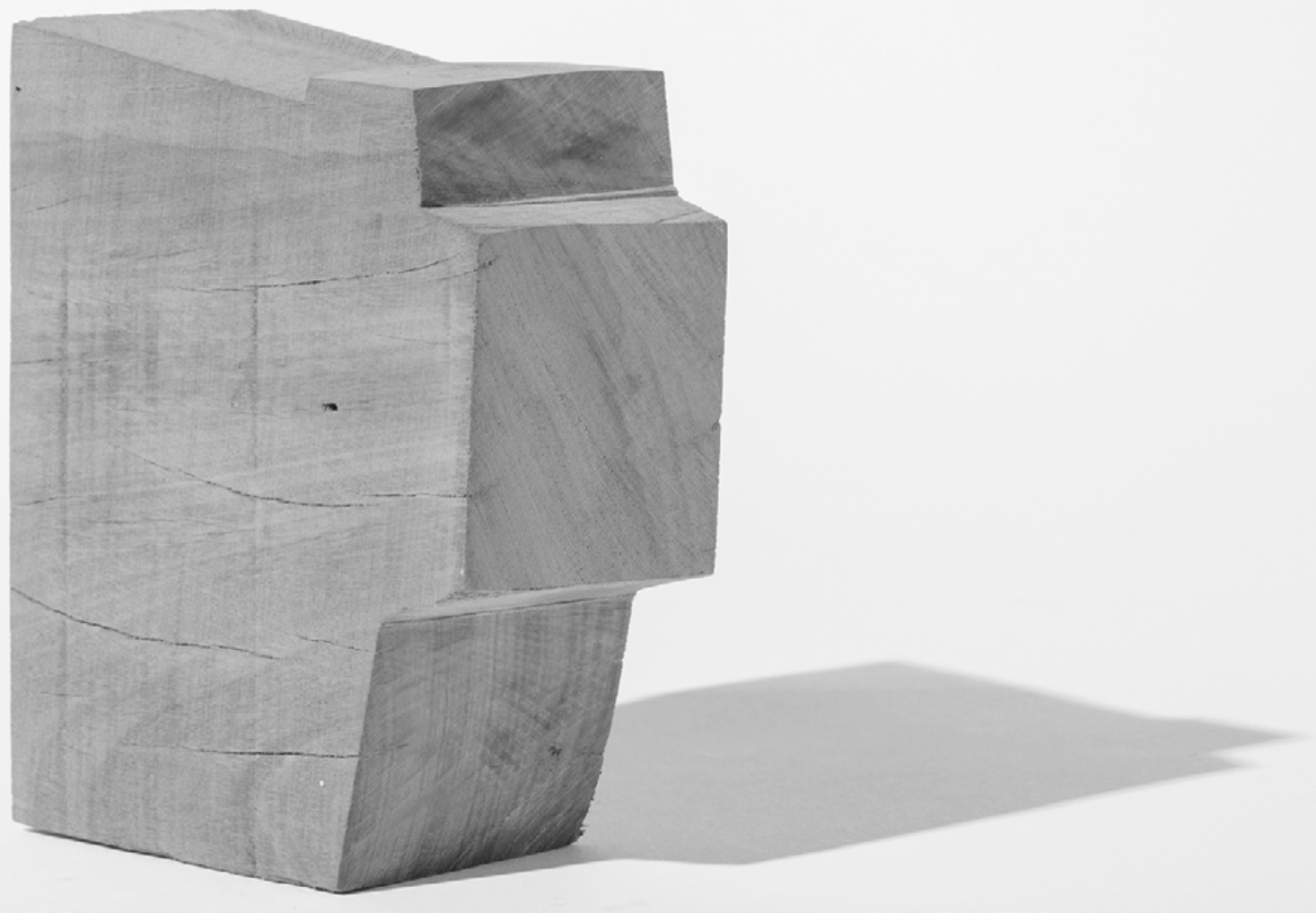



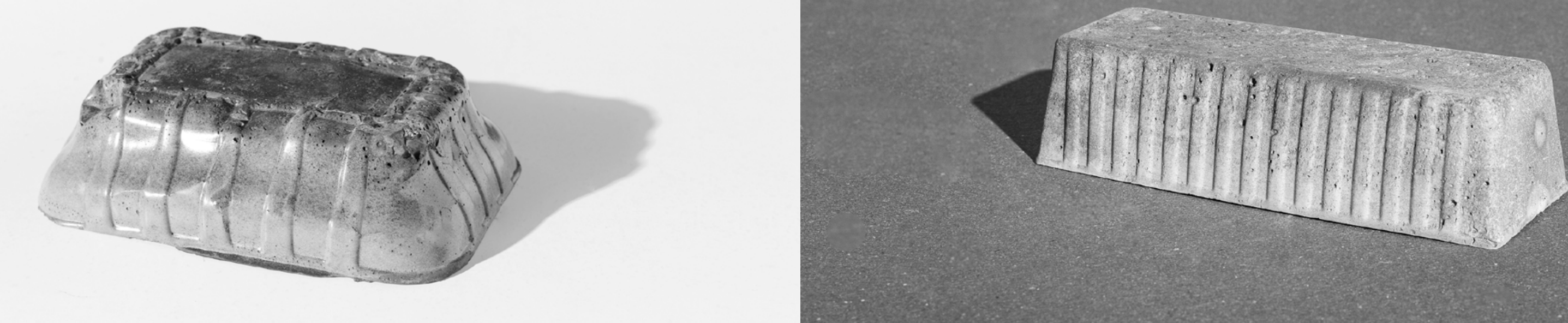


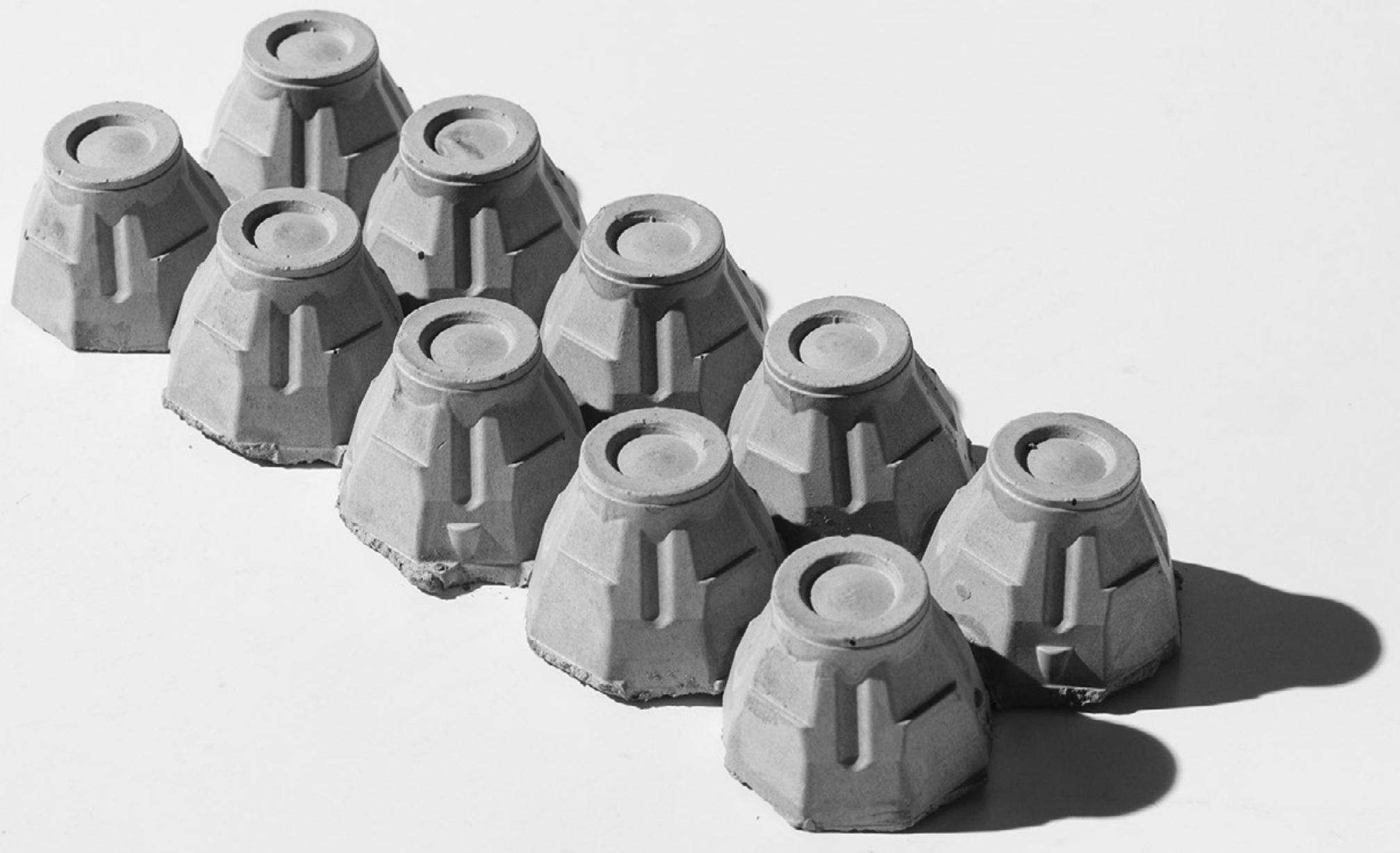



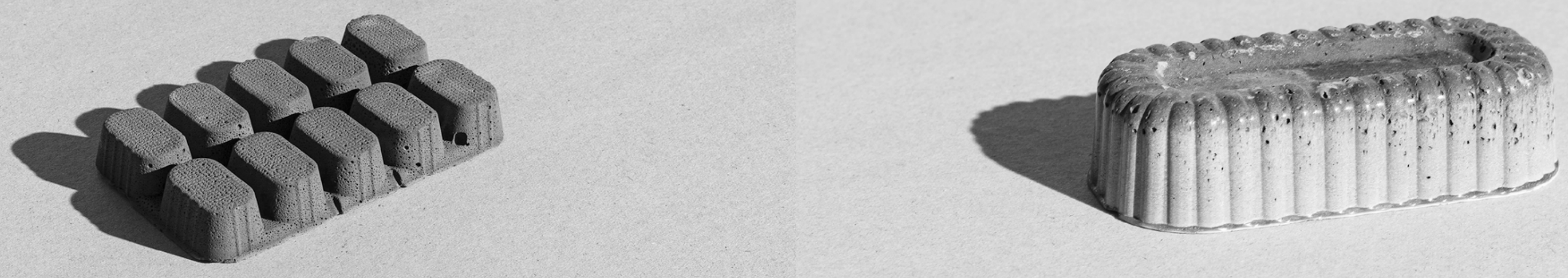


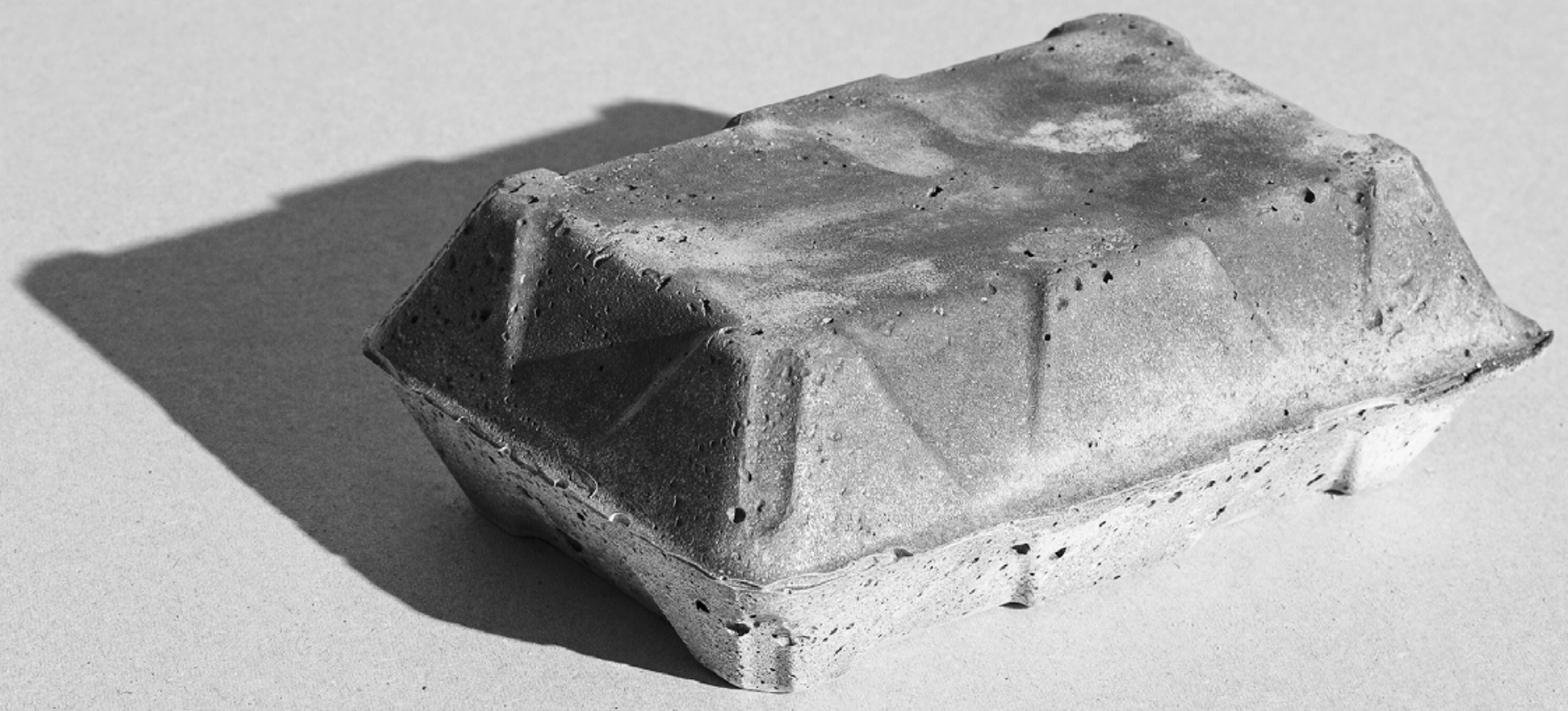



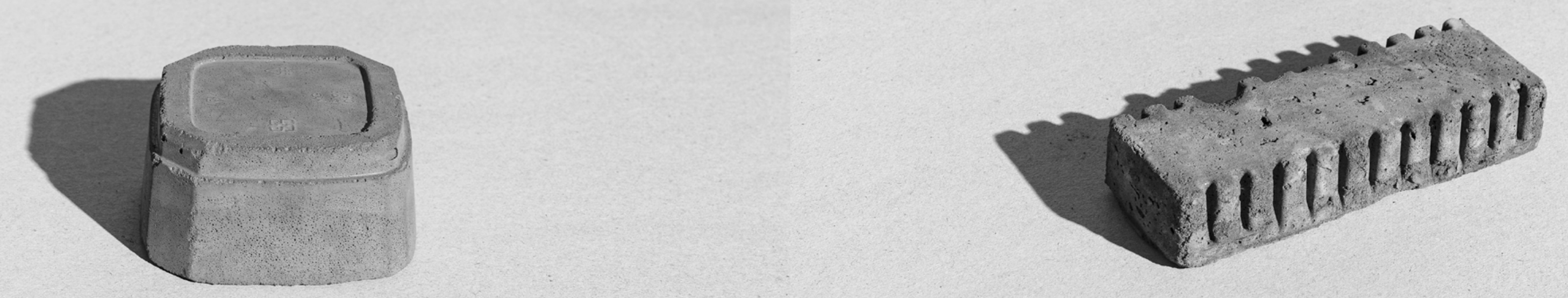


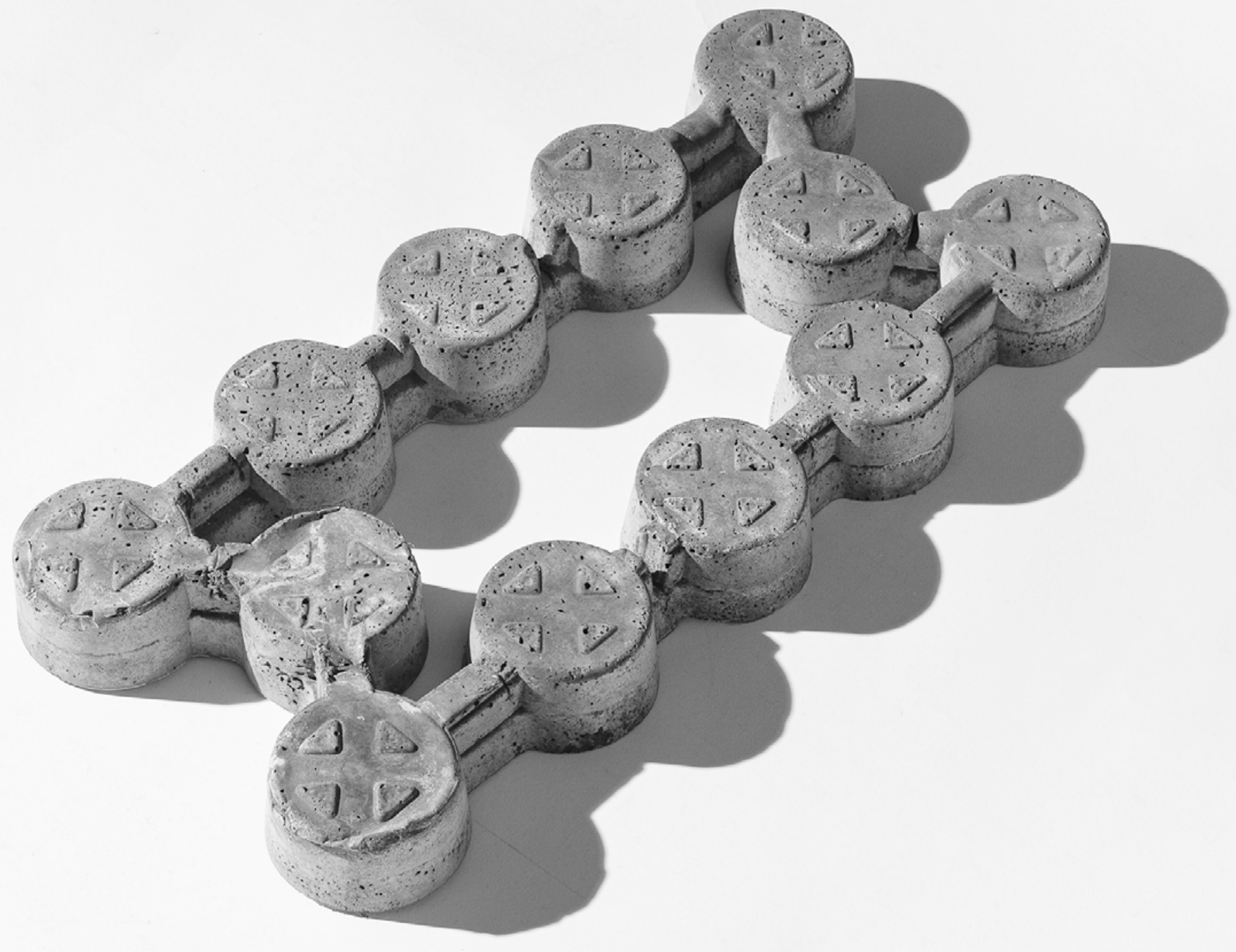




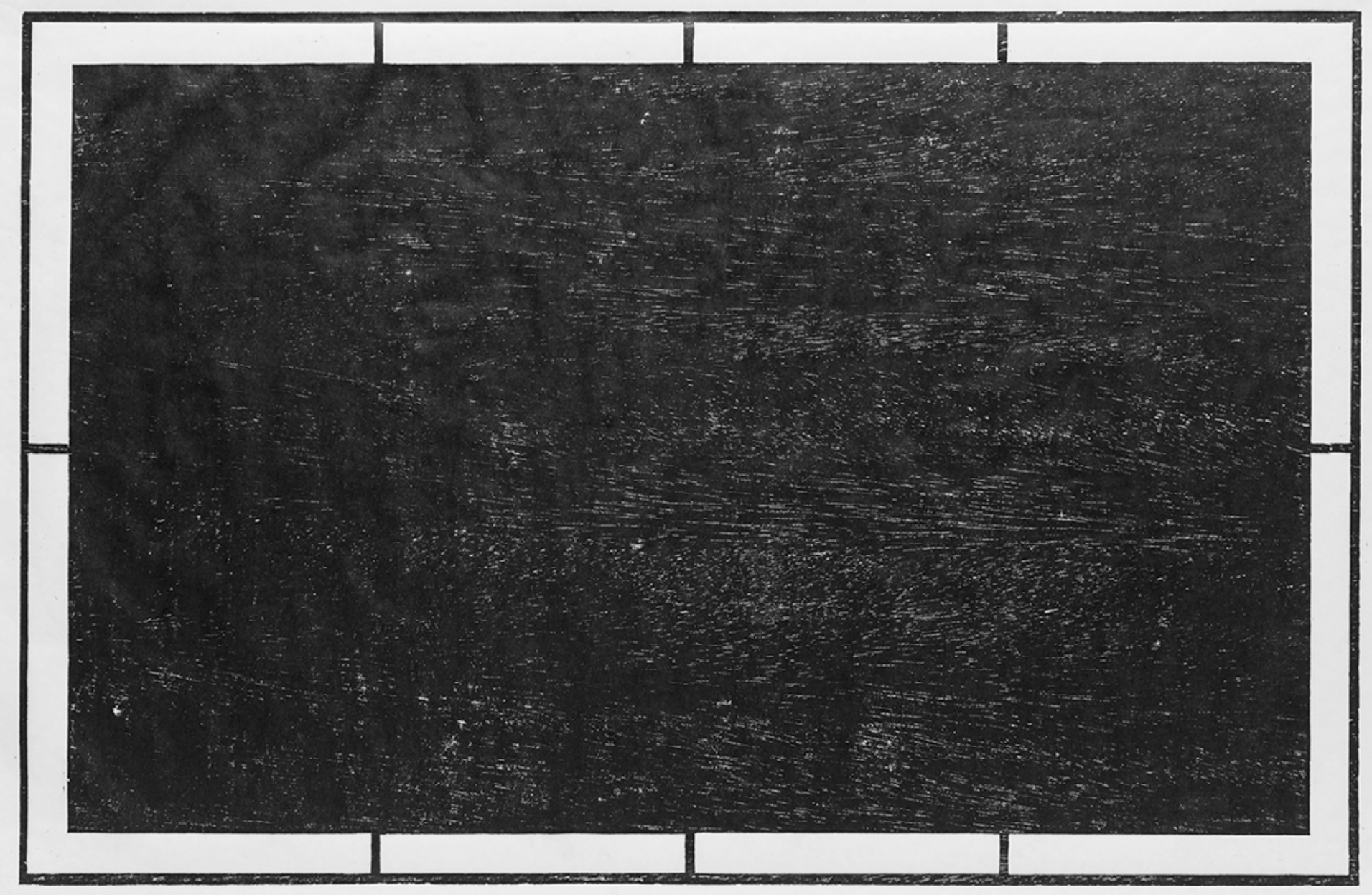




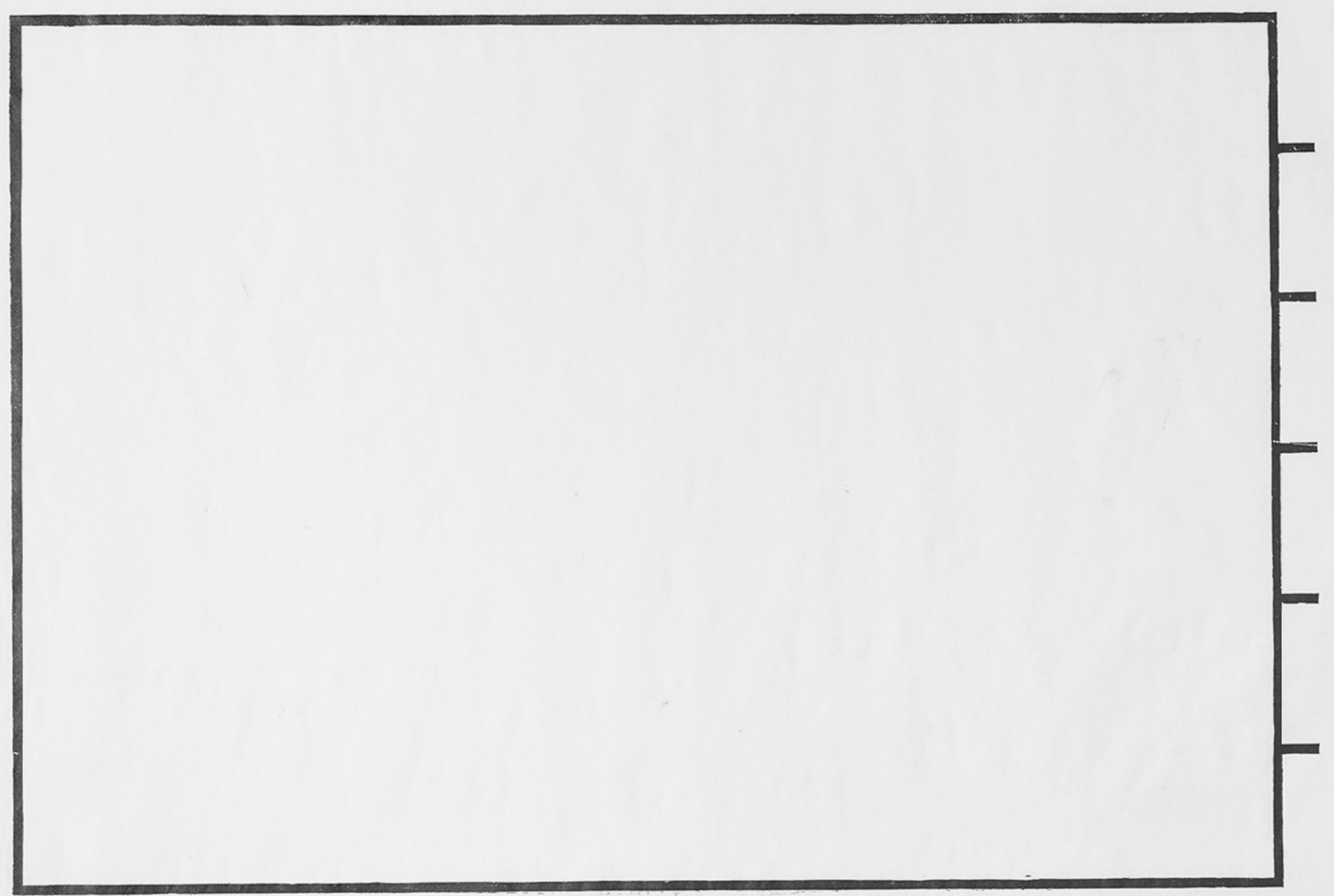




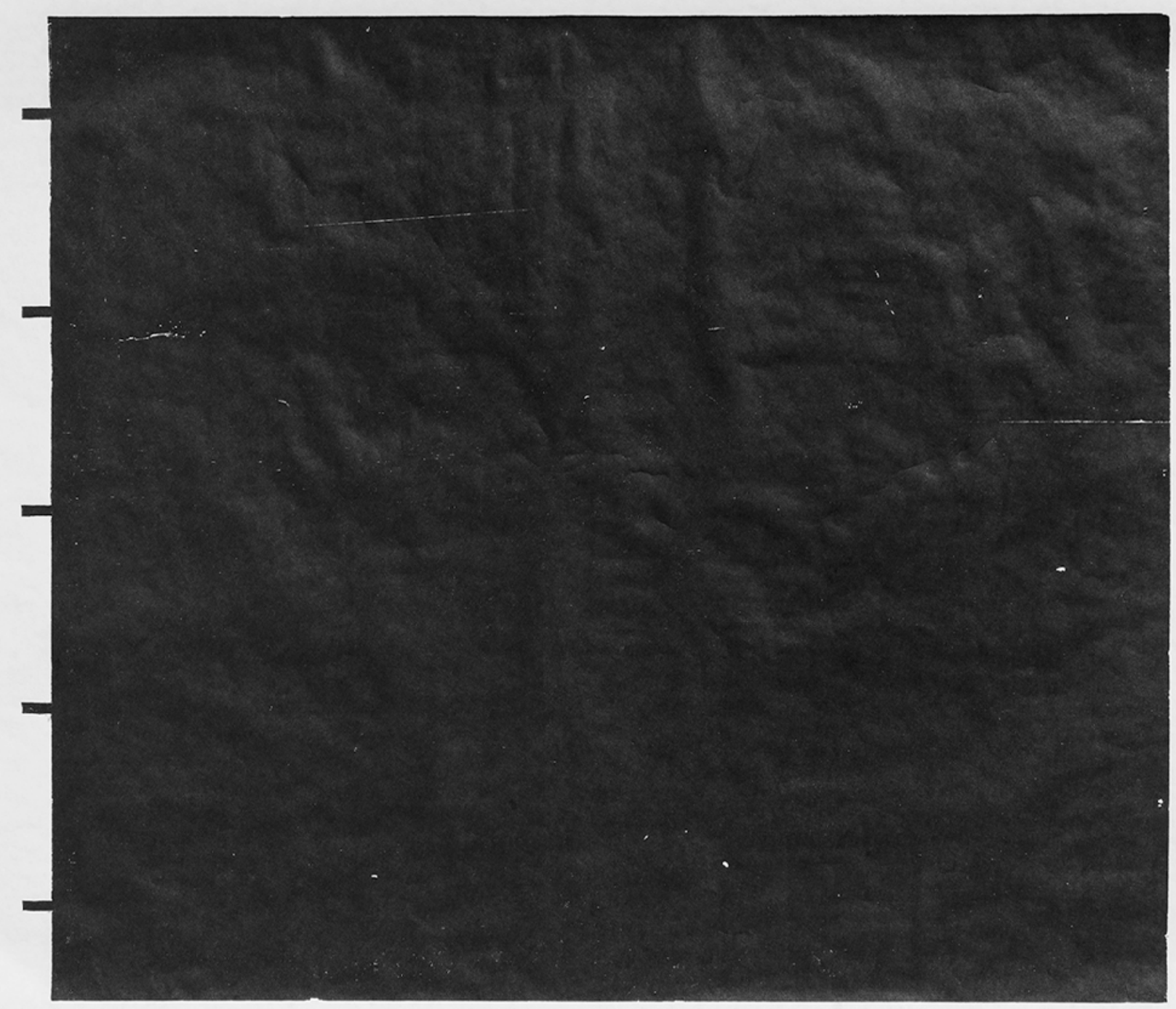




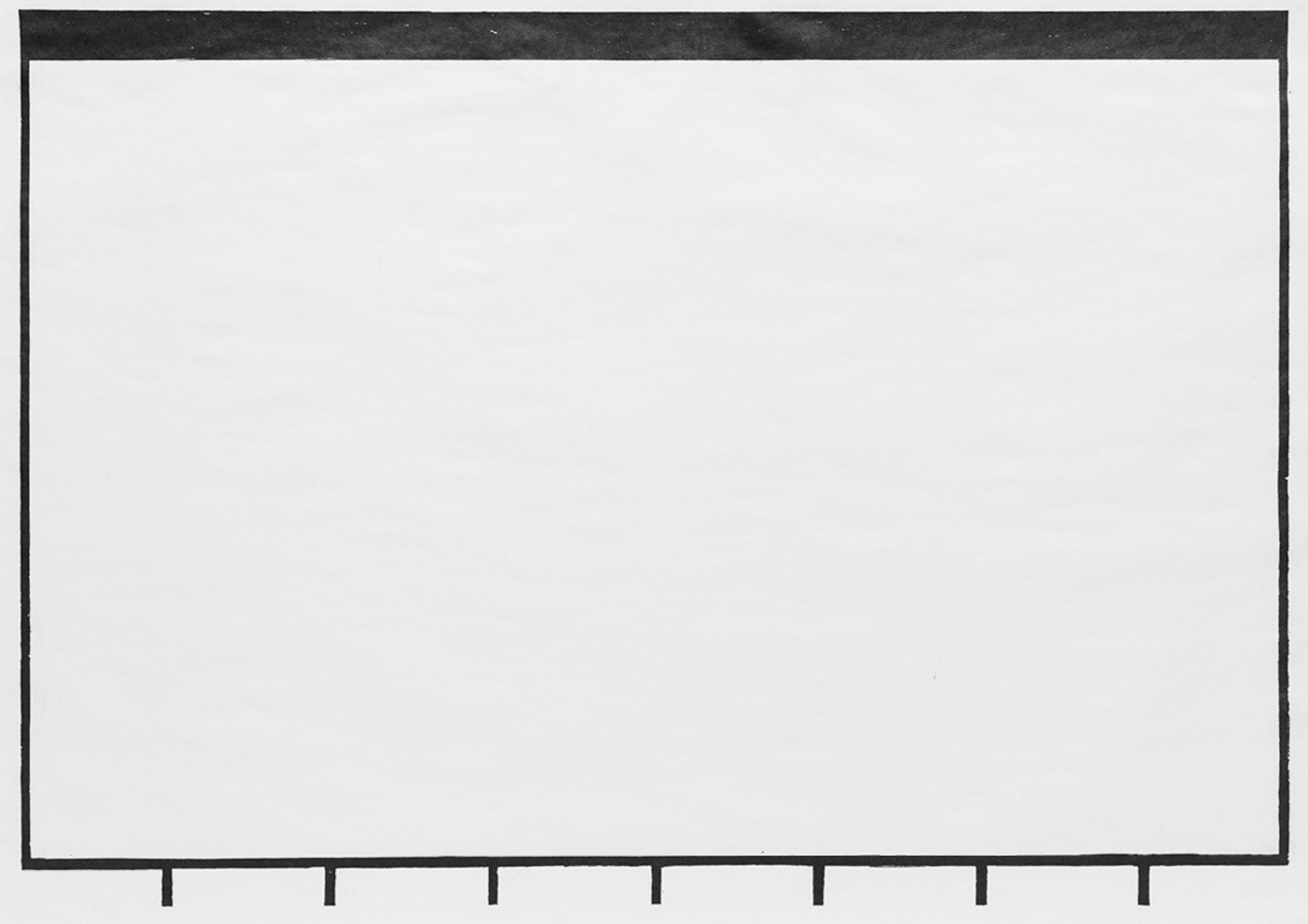




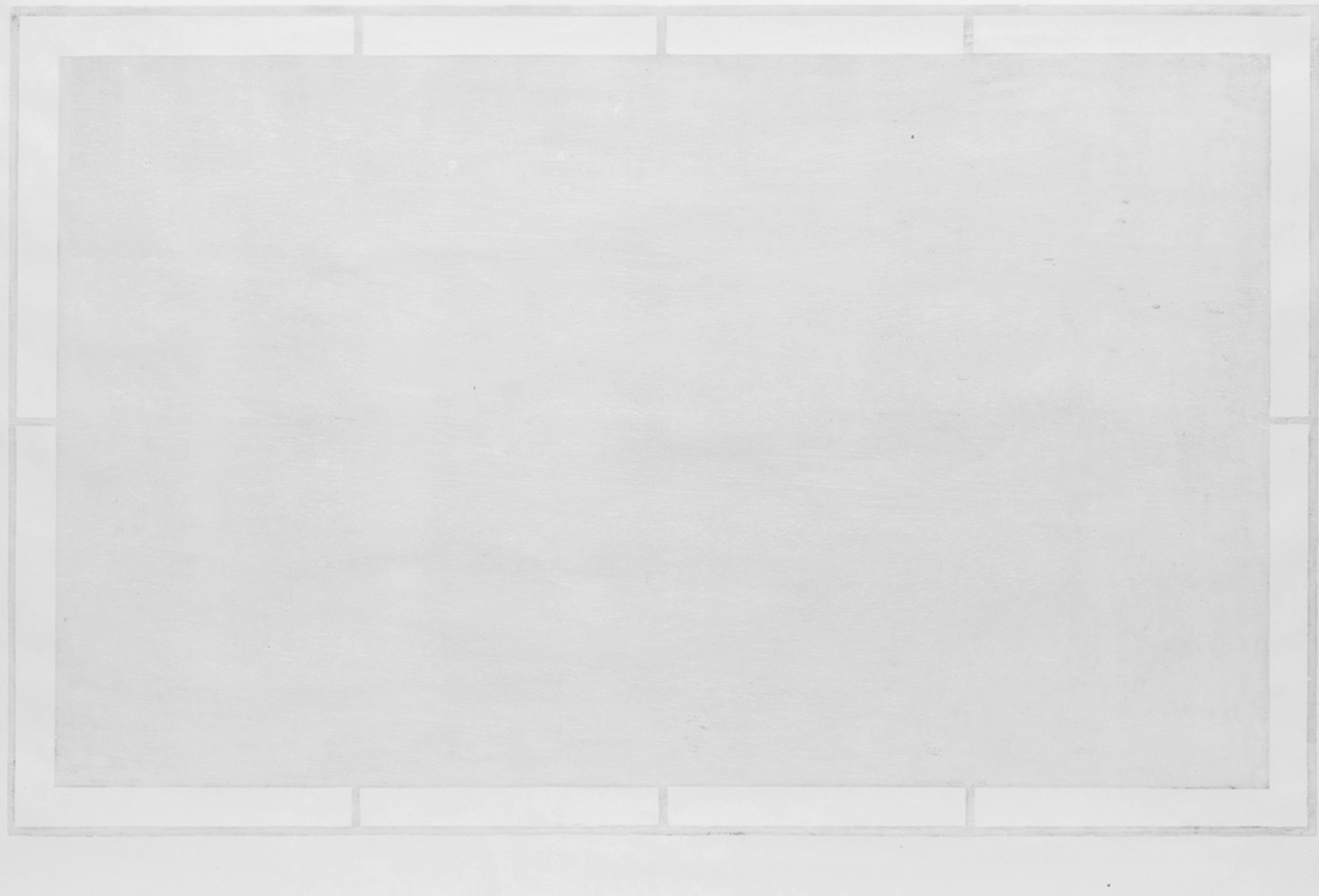





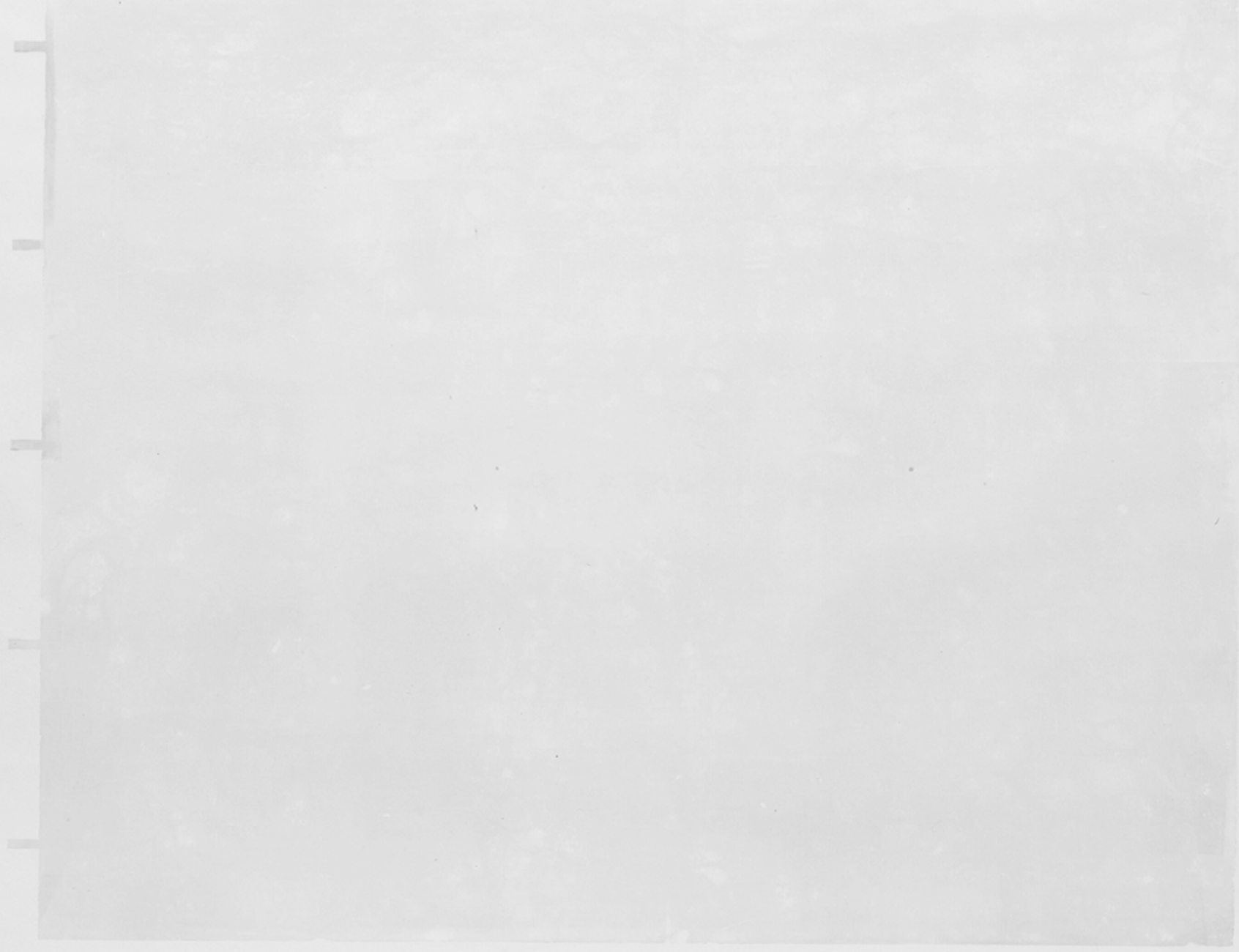




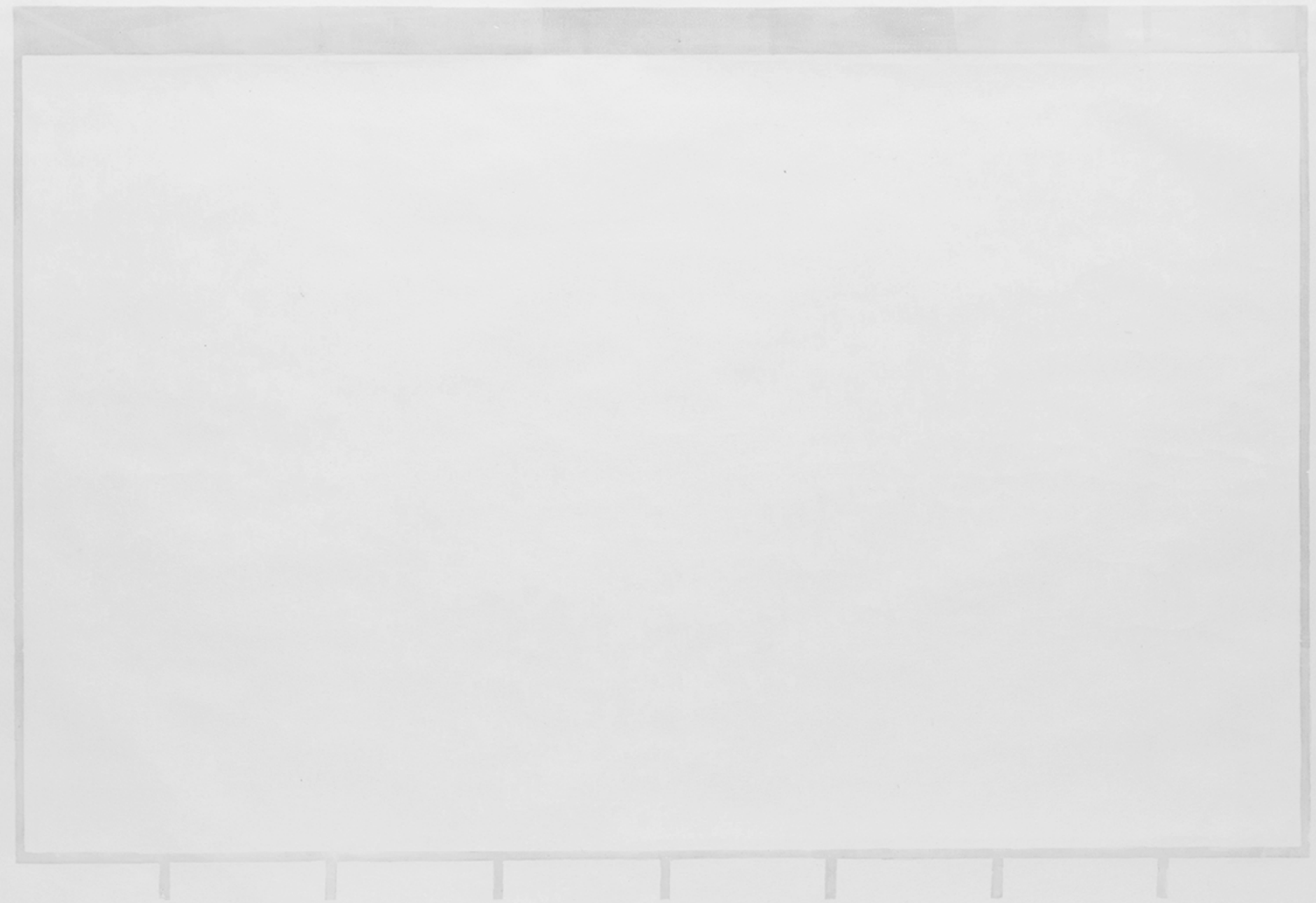




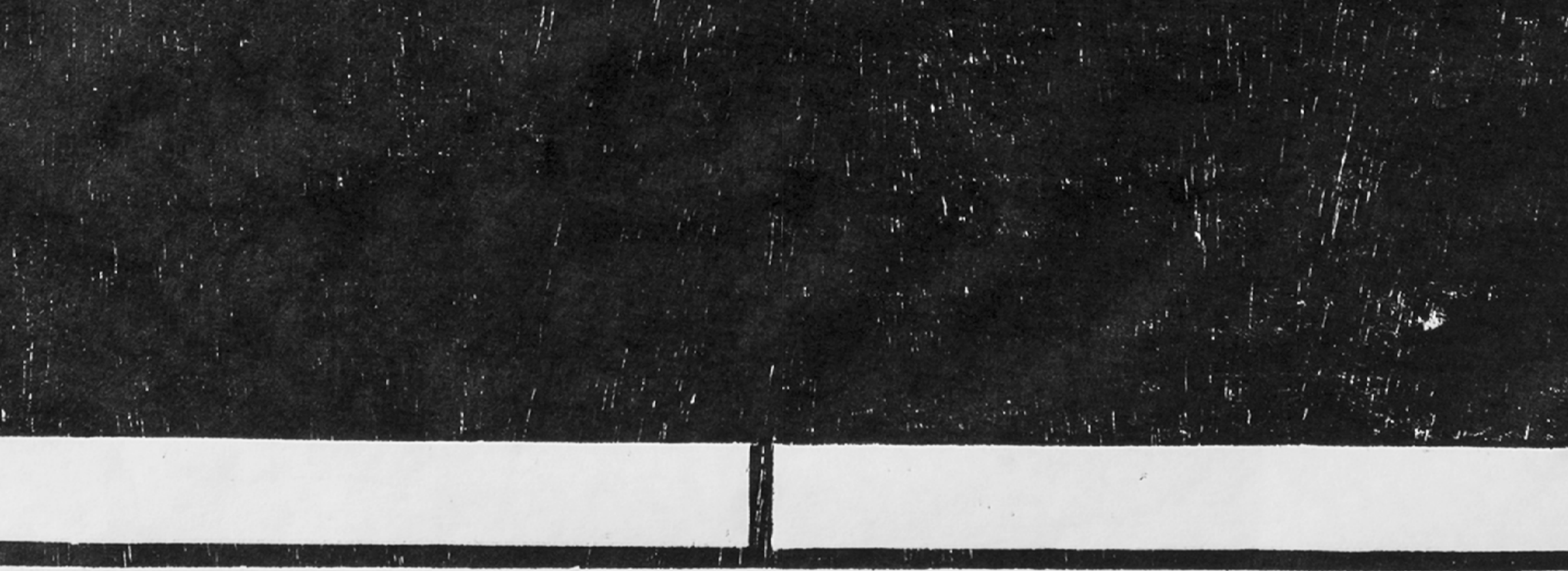







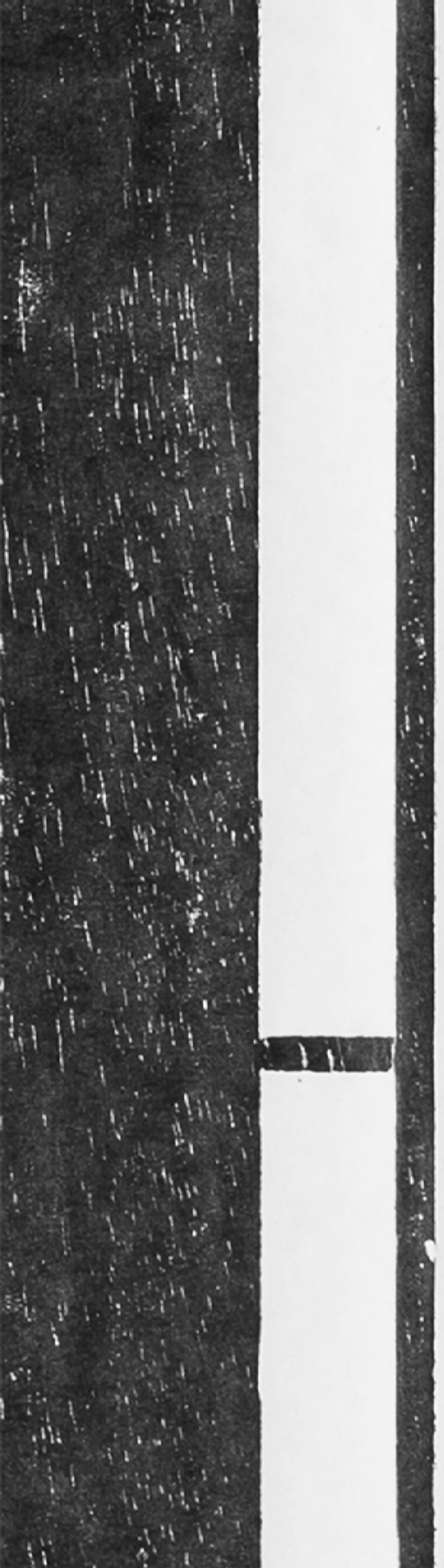




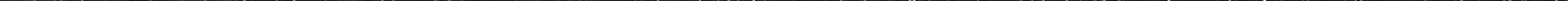




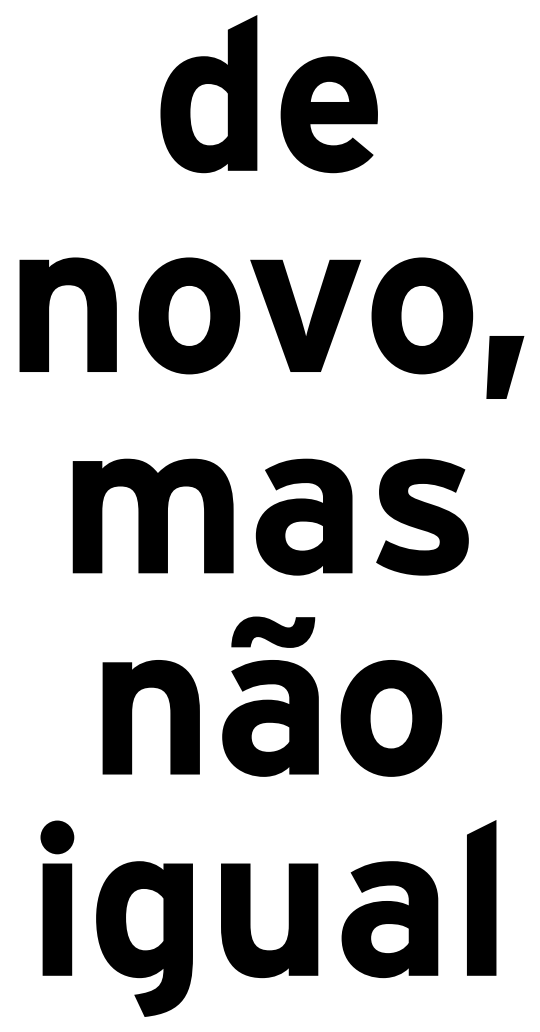


Mirella de Almeida Marino

\section{de novo, mas não igual}

Trabalho artístico apresentado ao Programa de Pós-Graduação em Artes Visuais da Escola de Comunicações e Artes da Universidade de São Paulo como requisito parcial para a obtenção do título de Mestre em Artes Visuais, sob orientação do Prof. Dr. Luiz Claudio Mubarac.

"Há uma falha em tudo É assim que a luz entra" São Paulo, 2020

Leonard Cohen 
0 volume apresentado reúne cinco cadernos com reproduções dos trabalhos desenvolvidos durante o mestrado, além de anotações que dizem respeito às referências estudadas neste período.

Embora os trabalhos estejam separados em diferentes cadernos e agrupados de acordo com seus procedimentos limpressão de objetos, fotografia, objetos tridimensionais e xilogravura), não há hierarquia entre eles, são meios utilizados simultaneamente no processo de trabalho. A escolha por apresentá-los desta maneira vem do desejo de que possam ser vistos em seus conjuntos e uns ao lado dos outros.

No caderno em que apresento as impressões de objetos, os trabalhos são parte de um grupo maior de estampas realizadas a partir de objetos coletados nas ruas da cidade e utilizados como matrizes.

0 procedimento se aproxima da monotipia na medida em que alguns objetos são tão frágeis que se desfazem no processo de impressão, gerando poucas cópias, enquanto outros podem ser impressos em maiores quantidades, dependendo da qualidade de seus materiais.

Os objetos recolhidos são entintados como matrizes de xilogravura e impressos manualmente com colher de pau ou em prensa, quando são planos e com pouca espessura.
0 papel usado é o pólen, por sua porosidade e por ser levemente amarelado.

As estampas são resultado da duplicação de um objeto por contato, um outro que já não é o mesmo embora guarde seu rastro. Sendo assim, a impressão tem as dimensões e características do que lhe foi matriz, como seu indício e prova de evidência, ao mesmo tempo em que revela desenhos só vistos a partir desta reprodução.

Os objetos que me interessam são aqueles que foram produzidos em escala industrial e desenhados a partir da lógica da maior eficiência possível para cada propósito e que, devido ao tempo de uso e abandono, adquiriram marcas e qualidades imprevisíveis, guardando apenas a memória de um desenho geométrico rigoroso.

Estes objetos, e suas impressões, não se referem a lugares específicos da cidade, são desenhos que poderiam estar em qualquer parte e que dizem respeito a algo comum ao cotidiano de uma grande cidade ou de quem nela vive. Não pretendo mapear um território, aquilo que me interessa é o que possuem de universal e ao mesmo tempo de singular.

No caderno de fotografias reúno registros realizados cotidianamente durante meus trajetos pela cidade. São imagens de rastros de fabricações humanas, sombras, 
estruturas de sinalização vazias, memórias de gestos, arranjos espontâneos e efêmeros de objetos descartados que resistem e insistem em permanecer, o desenho das coisas que estão em vias de desaparecer.

Vejo-os como elementos que materializam o mesmo jogo entre precisão e imprecisão que busco nos objetos coletados e seus registros me interessam como anotações, podendo desdobrar-se em outros trabalhos ao mesmo tempo em que possuem autonomia.

No caderno de objetos tridimensionais apresento trabalhos realizados a partir de um procedimento, que até então não havia utilizado, em que embalagens coletadas são usadas como matrizes para moldar volumes em gesso e em argamassa. Os trabalhos em madeira foram feitos a partir da ideia de extrusão em que um desenho bidimensional é projetado em uma terceira dimensão gerando um volume.

Neste caso, os objetos coletados são também matrizes e aquilo que resulta da moldagem também é impressão, revelando desenhos até então invisíveis de suas estruturas originais, criando um corpo para aquilo que era superfície e continente.

Também fazem parte deste grupo de trabalhos duas séries de xilogravuras realizadas a partir das mesmas matrizes, com desenhos que trazem a memória das anotações realizadas na cidade. Cada série é composta de quatro gravuras impressas ora em preto, buscando o protagonismo do desenho, ora com tinta sem pigmento, na tentativa de resgatar o modo como essas estruturas encontram-se como que camufladas em meio ao caos de informações visuais da cidade.

Como em um caderno de notas, reúno textos e imagens de outros autores e artistas coletados durante 0 período de desenvolvimento do mestrado e que me ajudam a refletir sobre o que é fundamental para meu trabalho.

Este conjunto particular de pistas indica que nele o ponto de partida é a própria experiência de estar em meio à profusão de imagens e acontecimentos da cidade, com particular atenção ao cotidiano e ao imprevisto, àquilo que parece repetitivo e igual mas que sempre pode nos surpreender, na medida da disponibilidade de nosso olhar.

Observar e registrar constituem minha maneira de acessar o mundo, conhecê-lo e investigá-lo, buscando, principalmente, um desenho que é constantemente retomado em diversos meios, sem nunca ser o mesmo ou aquele primeiro, em tentativas insistentes de apreender algo de essencial daquilo que se viu. 
“Realidade e realização: o criador [realista] que anseia pelo acidental. 0 objeto que emerge no mundo como resultado de um fenômeno e acaso imprevisíveis, mas apenas quando há um ato de consciência - consciência provocada pela realidade do corpo pronto para recebê-lo. Os destinatários: a surpresa do criador e a surpresa subsequente daquele que se dá conta: quem ativa a realidade como destinatário de seu futuro, aquele que percebe o que está the está acontecendo no mundo. Aceitação do real e seus acasos. Aceitação da frustração.

Não ter expectativas, não ser espectadores, e sim realizadores de acasos, nos quais a realidade nos presenteia, quando dela nada mais se espera."

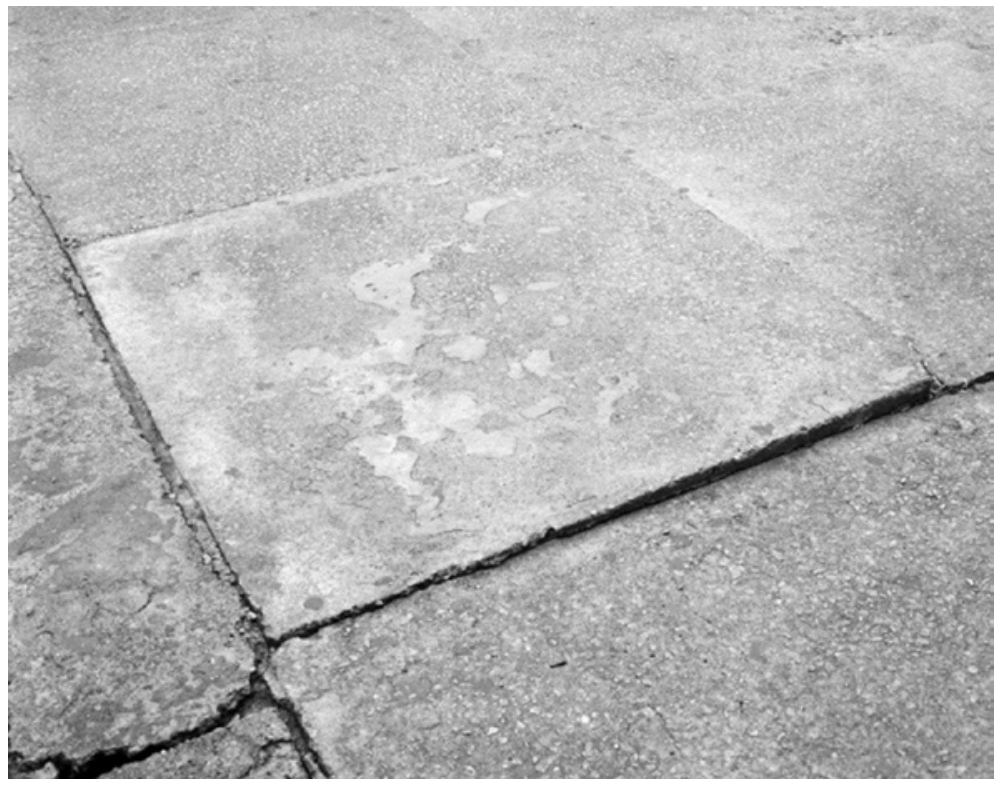




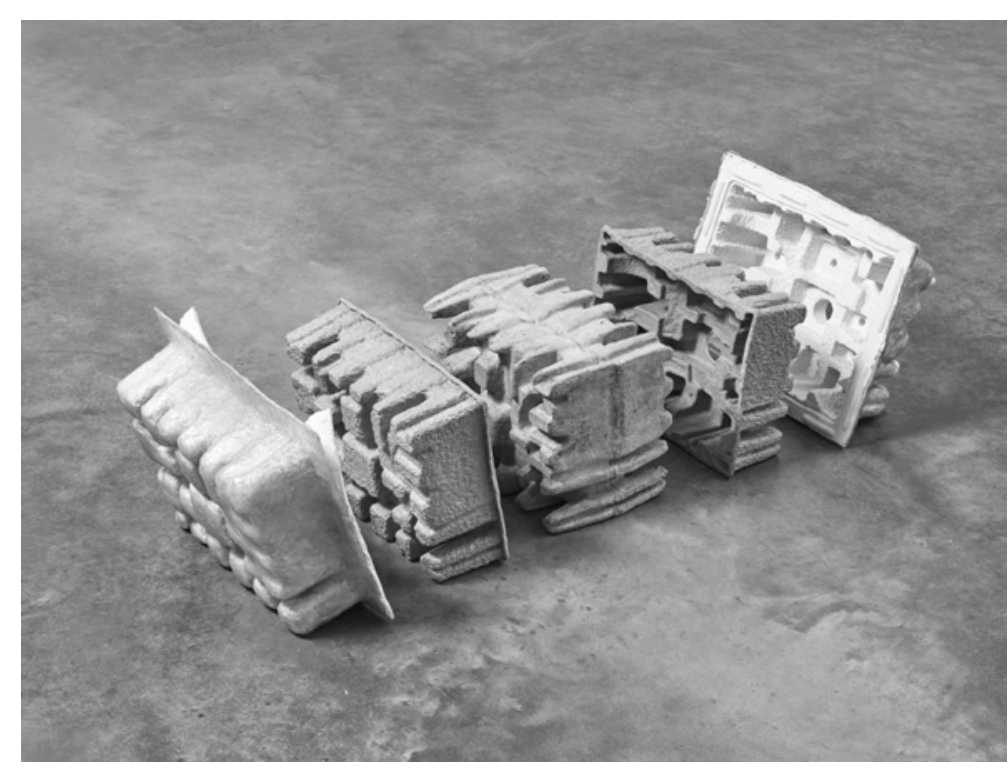

Damian Ortega, Genealogy of anything, 2017
“Quanto mais longínquo o valor de uso da coisa, mais valor esta adquiria para o trabalho. (...) Assim passou a capitalizar obsessivamente no âmbito das coisas desvalorizadas. Colocou todo seu investimento no não valor. (...) como se a artista não quisesse alterar a personalidade do objeto, do qual descobria e acentuava características únicas. Passou a interessar-se e procurar revelar com a maior precisão possível o modo como o tempo trata diversa e desigualmente aquilo que é produzido igual; é essa ação imprevisível e inconstante que mobiliza o trabalho, e é aí que ele encontra sua riqueza."

Paulo Venancio Filho sobre o trabalho de Fernanda Gomes, 2006 
“Por que, afinal, falar de antropologia em tal contexto? Porque cada impressão libera uma espécie paradoxal de eficiência ou magia - especialmente, a de ser ao mesmo tempo singular como corpo e universalizável como reprodução em série; a de produzir semelhanças extremas que não são mimese, mas duplicação; ou ainda a de produzir essas semelhanças como negativos, contra-formas, dessemelhantes. Entretanto, essa eficiência refere-se a alguns dos problemas mais fundamentais da hominização: o gesto técnico, a questão genealógica, o poder que as imagens têm de nos tocar, a invenção de uma memória de formas, o jogo cruel do desejo e do luto. Tudo isso em um contato triplo - por vezes alegre por vezes doloroso - com a matéria, com a carne, com o desaparecimento."

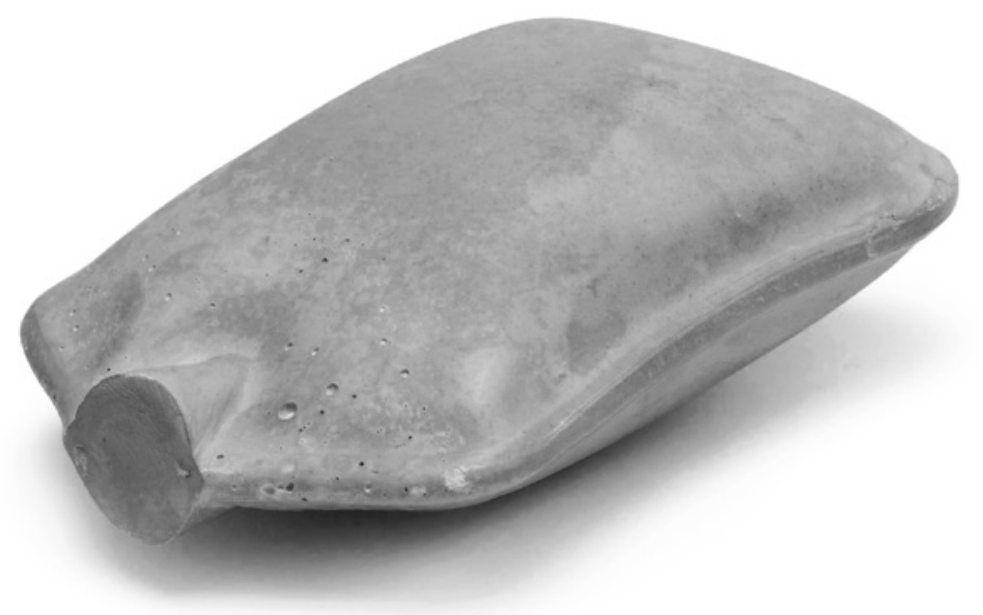


“Sinto certo afeto pelas marcas: não ligo quando o copo suado deixa rastros no tampo de madeira da mesa, não me importo com objetos que se quebram um pouco mas não deixam de funcionar. Quanto mais histórias as coisas têm, a falha, a marca, a ausência, tudo isso vive pela coisa."

Gabriela Aguerre, 0 quarto branco, 2019
“Ver não é um fenômeno apenas retiniano, mas já pensar. 0 olhar está simultaneamente voltado para dentro e para fora, tanto recebe como projeta, revela e se revela. Fixando o concreto, vê-se também uma lembrança, um desejo, um pensamento. (...) Na única construção possível, confluem o espaço recordado, o espaço vivenciado, o espaço desejado."

Marco Buti, Estruturas inevitáveis: continuidade do gravar interior, 1994 
“(...) A insistente manipulação resulta em um deslocamento que remete os trabalhos à uma curiosa condição fronteiriça: incorporando a tensão visual entre as ressonâncias originárias de elementos capturados da cena urbana à mais absoluta autoreferência, os desenhos adquirem o estatuto de quase-objetos deslocados em trânsito incerto. (...) os trabalhos não remetem à nenhum horizonte idealizante: o "grau zero" da forma aqui pretendido é antes cúmplice do resíduo, do eterno provisório."

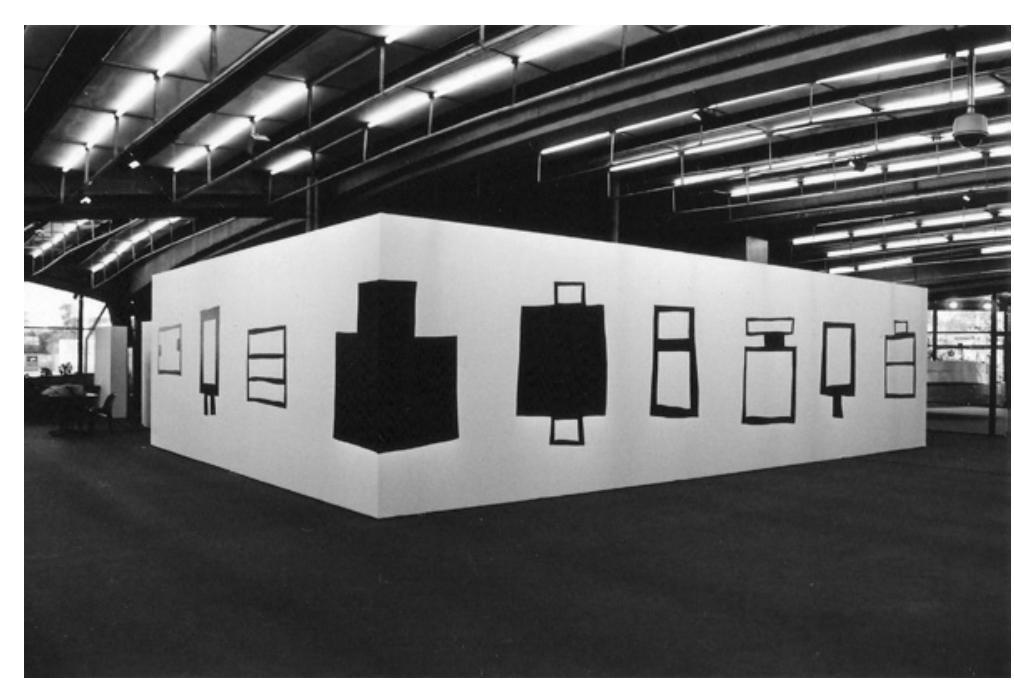

Mirella Marino, Sem título, 2003 
“É quando alguém, por exemplo, se volta para algo que lhe chama em meio aos afazeres cotidianos e sente formar um novo sentido, insuspeitado, para o que já via e conhecia de um outro modo. É esse vento repentino que me leva a olhar a copa agitada da árvore fora de minha janela e que me apanha antes que o percebido e o cotidiano se intrometam. Nessa surpresa, o tempo como que demora, como que pára um pouco e me dá o presente em que traço da árvore o desenho - e que ela por sua vez também me desenha - da agitação de suas folhas e de seus galhos. É nesse coincidir de dois desenhos, que são um só, e no qual o que percebo como que o crio e o que crio como que já me esperava para desvendá-lo, que percebo como se nunca tivera percebido." 
“Um desenho de observação revela muito de mim. Nos outros desenhos - nos desenhos feitos com a fantasia - faço apenas o que quero e mostro a mim e ao mundo como bem entender, ao passo que, no desenho de observação, o protagonista já não sou eu, que me torno uma espécie de servo, de personagem secundário. Sou arrastado de tal maneira pela realidade que tenho diante de mim que esqueço de mim mesmo e trabalho como em transe, buscando singularizar a realidade, fazendo o desenho sem me dar conta de que o estou fazendo. E assim tenho medo de que o desenho revele certas partes de mim mesmo, certas zonas de vulgaridade em que não digo a verdade, lanço mão do que já sei, dos lugares-comuns, e vejo em mim mesmo, isto é, no desenho que estou fazendo, alguns dos meus defeitos constantes: terminar sem terminar, cansar e renunciar a insistir num ponto que seria essencial; por timidez ou por preguiça, deixo de insistir, e assim as coisas não terminam como deveriam, a promessa é mais abundante que o resultado. Há por vezes alguma coisa de sedutor no que faço, mas que seria bom de verdade se eu continuasse seriamente até o fim, se mantivesse a promessa."

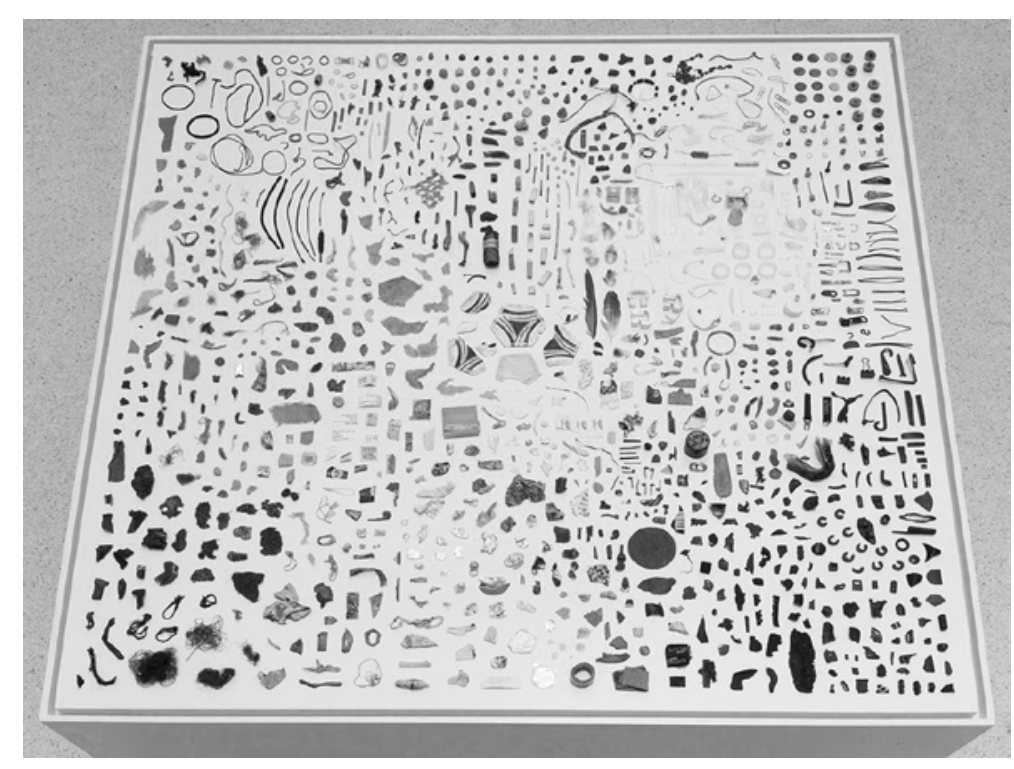

Gabriel Orozco, Astroturf Constellation, 2012 


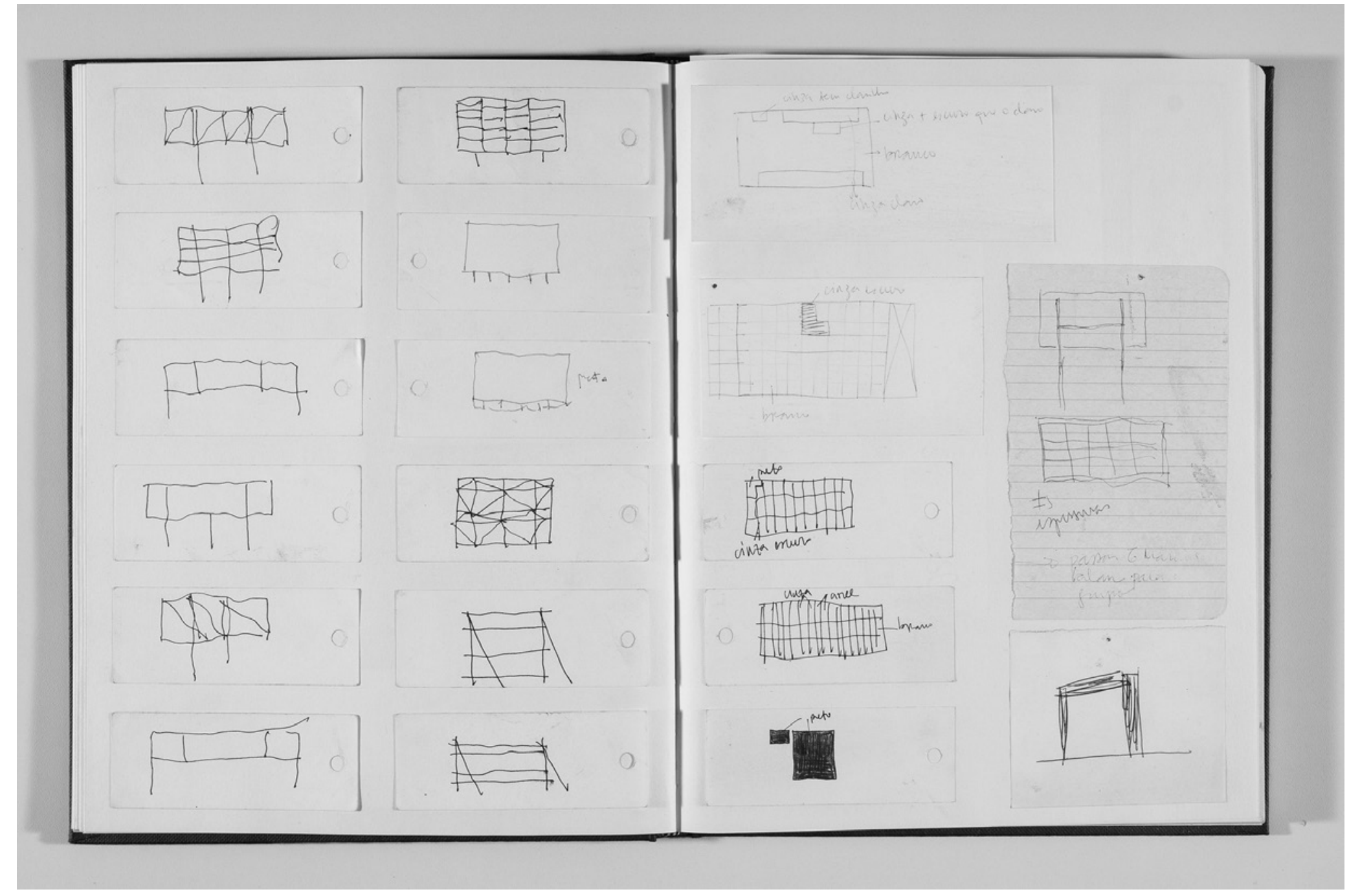

Caderno de desenhos 
Dizer: fazer

a Roman Jakobson

1.

Entre o que vejo e digo, entre o que digo e calo, entre o que calo e sonho, entre o que sonho e esqueço, a poesia.

Desliza

entre o sim e o não:

diz

o que calo,

cala

o que digo,

sonha

o que esqueço.

Não é um dizer:

é um fazer.

É um fazer

que é um dizer.

A poesia

se diz e se ouve:

é real.

E logo que digo

é real,

se dissipa.

Assim é mais real?
2.

Ideia palpável,

palavra

impalpável:

a poesia

vai e vem

entre o que é

e o que não é.

Tece reflexos

e os destece.

A poesia

semeia olhos na página,

semeia palavras nos olhos.

Os olhos falam,

as palavras olham,

os olhares pensam.

Ouvir

os pensamentos,

ver

o que dizemos,

tocar

o corpo da ideia.

Os olhos

se fecham,

as palavras se abrem.

Octavio Paz, "Arbol adentro - Poemas", 1976-1988

(Tradução de Eduardo Jardim) 


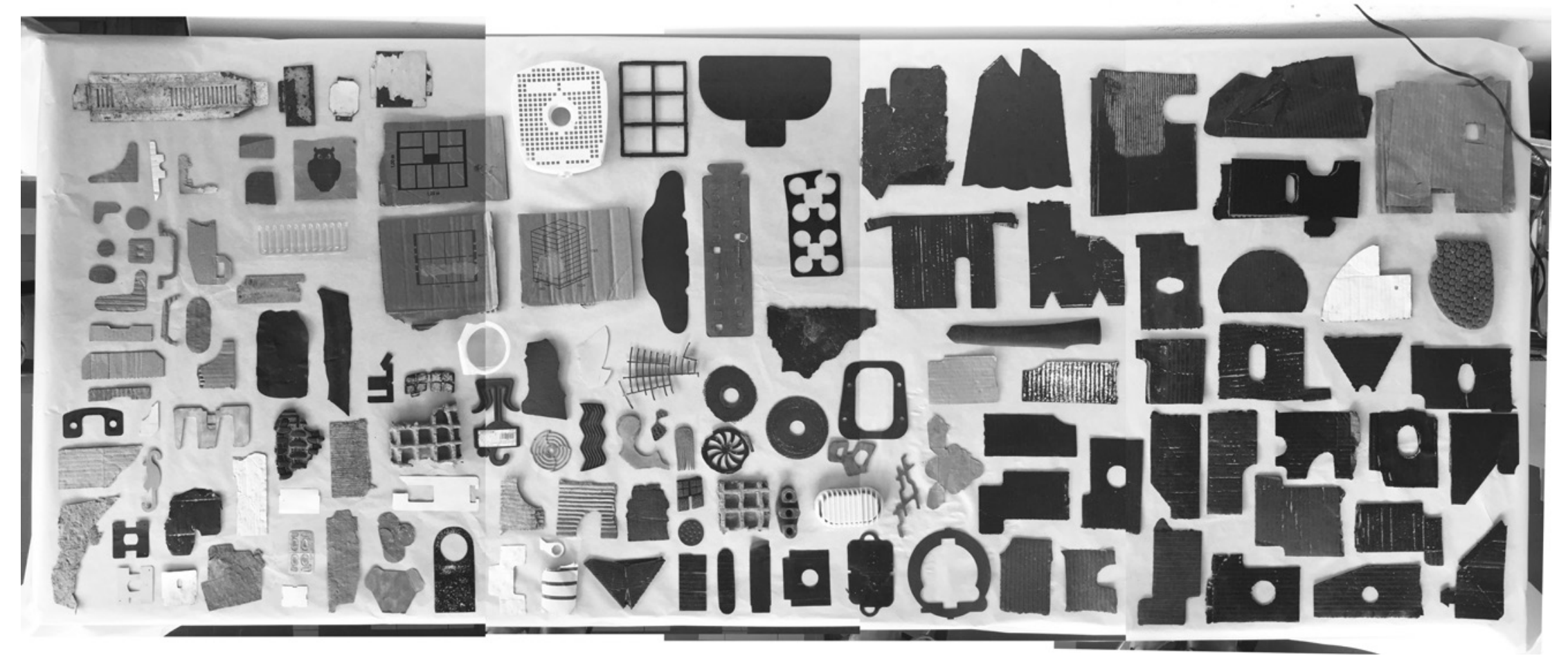

Objetos coletados, 2017/20 


\section{Referências de leitura}

AGUERRE, Gabriela. 0 quarto branco. São Paulo: Todavia, 2019. 120p.

BERLIN, Lucia. Manual da faxineira. São Paulo: Companhia das Letras, 2017. 536p.

BRETT, Guy. Between work and world: Gabriel Orozco. In: BOIS, Yves-Alain. Gabriel Orozco. Cambridge (MA): The MIT Press, 2009. p.51-58

BUCHLOH, Benjamin H. D. Cosmic Reification: Gabriel Orozco's Photography. In: BOIS, Yves-Alain. Gabriel Orozco. Cambridge (MA): The MIT Press, 2009. p.139-156

BUTI, Marco. Estruturas inevitáveis: continuidade do gravar interior. Dissertação de Mestrado. São Paulo: Departamento de Artes Plásticas, Universidade de São Paulo, 1994.

CERTEAU, Michel de. A invenção do cotidiano: 1. Artes de fazer. São Paulo: Editora Vozes, 2011. 320 p.

DAVIS, Lydia. Tipos de perturbação. São Paulo: Companhia das letras, 2013. 256p.

Nem vem. São Paulo: Companhia das letras, 2017. 360p.

DIDI-HUBERMAN, Geroges e SEMIN, Didier. Faire une empreinte... In: L'Empreinte. Catálogo da exposição L'Empreinte, Centre Georges Pompidou, 1997. Paris: Éditions du Centre Pompidou, 1997. 336p.

FOCILLON, Henri. 0 elogio da mão (livro eletrônico). Tradução de Samuel Titan Jr. São Paulo: IMS, 2012. (Clássicos Serrote), 193Kb, PDF.

HUDEK, Anthony (ed.). The object. Cambridge (MA): The MIT Press, 2014. p. 116-117

KINROSS, Robin; MARTENS Karel; VAN TRIEST, Jaap. Printed Matter. London: Hyphen Press, 2010. 168 p. 
MARTENS, Karel. Karel Martens: Counterprint. Londres: Hyphen Press, 2004. 28p.

MERLEAU-PONTY, Maurice. A dúvida de Cézanne. In MERLEAUPONTY, Maurice. 0 olho e o espírito. São Paulo: Cosaq \& Naify, 2013. p.

OROZCO, Gabriel. Lecture. In: BOIS, Yves-Alain. Gabriel Orozco. Cambridge (MA): The MIT Press, 2009. p.85-104

PAZ, Octavio. 0 Arco e a Lira. Rio de Janeiro: Nova Fronteira, 1982.

. Marcel Duchamp ou o Castelo da pureza. São Paulo:

Perspectiva, 1977. 95p.

RUSSO, Felipe. Centro. São Paulo: Ed. do Autor, 2014.

SPECTOR, Nancy. Mapping the universe. In: The object. Cambridge (MA): The MIT Press, 2014. p. 116-117

STEINBERG, Saul. Reflexos e sombras. São Paulo: IMS, 2011. $178 p$.

WHITEREAD, Rachel; ROSE, Andrea. Interview [1997]. In: WOOD, J.; HULKS, D.; POTTS, A. Modern Sculpture Reader. Leeds: Henry Moore Institute, 2007, p.449 a 462.

VENANCIO FILHO, Paulo. Corpos sem alma. In: Rachel Whiteread. Catálogo da exposição Rachel Whiteread, Museus de Arte Moderna do Rio de Janeiro e de São Paulo, 2003- 2004. Rio de Janeiro: ARTVIVA, 2003. p. 27-77.

. Lugares. In: A presença da arte. São Paulo: Cosaq Naify,

2013. p. 174-179.

\section{Sites consultados}

https://www.guggenheim.org

https://feliperusso.com

https://www.tate.org.uk

https://artreview.com/

https://www.moma.org/

https://www.kurimanzutto.com/ 


\section{Informações dos trabalhos}

Caderno de impressão de objetos

Os trabalhos apresentados fazem parte da série em andamento entitulada "Impressão de objetos"

Tinta offset preta sobre papel pólen

$47 \times 65 \mathrm{~cm}$

$2018 / 2020$

Caderno de fotografias

Sem título

32 fotografias digitais

$13 \times 18 \mathrm{~cm}$ (cada)

$2011 / 2020$

Caderno de objetos tridimensionais

Sem título

Argamassa, madeira ou gesso

$28 \times 9 \times 3 \mathrm{~cm}, 13 \times 5,5 \times 9 \mathrm{~cm}, 12 \times 13 \times 19 \mathrm{~cm}, \varnothing 12 \times 1,5 \mathrm{~cm}, 16,5 \times 9 \times 14 \mathrm{~cm}$, $4 \times 4 \times 7 \mathrm{~cm}$ (cada elemento), $\varnothing 19 \times 2 \mathrm{~cm}, 20 \times 14 \times 5,5 \mathrm{~cm}, 27 \times 17 \times 4 \mathrm{~cm}$, $6 \times 6 \times 4,5 \mathrm{~cm}, 13 \times 11,5 \times 6 \mathrm{~cm}, 13 \times 9 \times 4 \mathrm{~cm}, 15,5 \times 6 \times 4,5 \mathrm{~cm}, 24 \times 10 \times 3,5 \mathrm{~cm}$, $13 \times 6 \times 3,5 \mathrm{~cm}, 13 \times 8 \times 2 \mathrm{~cm}, 19 \times 12 \times 6,5 \mathrm{~cm}, 9 \times 9 \times 5 \mathrm{~cm}, 16,5 \times 6 \times 3 \mathrm{~cm}$, $55 \times 26 \times 5,5 \mathrm{~cm}$

$2018 / 2020$

Caderno de xilogravuras

Sem título (da série "Estruturas")

Tinta offset preta e tinta incolor sobre papel Okawara $73 \times 100 \mathrm{~cm}$

$2018 / 2019$

Crédito das imagens: Nino Andrés Biasizzo 


\section{Resumo}

De novo, mas não igual é uma caixa contendo cinco cadernos, cada um deles apresentando trabalhos realizados durante 0 mestrado por meios como a impressão de objetos, a fotografia, a xilogravura, a construção de objetos tridimensionais e anotações textuais e visuais coletadas neste período. 0 que os atravessa é uma compreensão particular de desenho, cujo eixo é o interesse por estruturas que guardam, simultaneamente, um aspecto padronizado e especificidades adquiridas pelo uso e pela ação imprevisível do tempo e do abandono. A cidade evocada em diversos registros, retorna como vestígio ou memória de objetos e situações prestes a desaparecer.

Palavras-chave: desenho, gravura, fotografia, objeto, cidade, cotidiano

\section{Abstract}

De novo, mas não igual (once again, but not the same) is a cardboard box containing five copybooks, each one presenting works performed during the Master's degree through means such as printing objects, photography, woodcut, construction of tridimensional objects and textual and visual notes collected within this period. A particular understanding of drawing crosses them, which axis is the interest for structures retaining simultaneously standardized aspects besides specificities assumed through use and the unpredictable action of time and by abandon. The city evoked in several registers, comes back as vestiges or memories of objects and situations about to disappear.

Keywords: drawing, engraving, photography, object, city, daily life 


\section{Agradecimentos}

Ao Claudio Mubarac, pela orientação generosa, sensível e paciente, além da alegria e do aprendizado de cada conversa Ao Marco Buti e à Celina Yamauchi, pelas sugestões preciosas na banca de qualificação

Aos professores Agnaldo Farias, Amanda Saba Ruggiero, João Musa, Maria Cecilia França Lourenço e Sumaya Mattar

À Anna Helena Villela, pelo incentivo inicial

Ao Antonio Ewbank, pela ajuda fundamental com o projeto de pesquisa À Silvia Amstalden, pela amizade e por todas as parcerias

À Mariana Vaz, por me proporcionar novas experiências na cidade e expandir as possibilidades para além do visível

Ao Edu Marin, pela longa amizade e por me abrigar no galpão-ateliê À Amália Barrio, por compartilhar sua sabedoria discreta me ajudando a dar forma ao trabalho

À Luciana Facchini, por seu olhar cuidadoso e certeiro

Às colegas e amigas da pós-graduação: Fabiane Carneiro, Livia Gabbai, Luanna Jimenes, Nara Isoda e Paula Gabbai

À turma da Firmo: Alexandre Barbosa, Caio Mazzilli, Douglas Garcia, Filipe Franco, Lila Botter, Marina Oruê e Thany Sanches

À todos do grupo Rotas do Desenho: Antonia Perrone, Arturo Gomero, Gabriela Gianotti, Nina Guedes, Raquel de Sá

Ao Nino Biasizzo, pela precisão no registro dos trabalhos Ao Augusto Sampaio, cujas palavras ecoam na minha cabeça e reverberam no trabalho

Ao Valdir Flores, pelos ensinamentos valiosos e pela convivência no ateliê Aos funcionários da ECA

Ao Rodrigo Blum, por me ajudar a organizar o caos das ideias e imagens para poder, às vezes, enxergar melhor

À Branca, cujo trabalho e afeto possibilitam o meu trabalho

Aos meus pais, Dulce e Julio, que sempre me incentivaram a seguir o meu caminho

Ao Shundi, por tudo: o seu olhar melhora o meu

À Nara e à Kimi, com quem aprendo e me divirto todos os dias

0 presente trabalho foi realizado com apoio da Coordenação de Aperfeiçoamento de Pessoal de Nível Superior - Brasil (CAPES) Código de Financiamento 001. 
Autorizo a reprodução e divulgação total ou parcial deste trabalho, por qualquer meio convencional ou eletrônico, para fins de estudo e pesquisa, desde que citada a fonte.

Catalogação na Publicação

Serviço de Biblioteca e Documentação

Escola de Comunicações e Artes da Universidade de São Paulo Dados inseridos pela autora

Marino, Mirella de Almeida

De novo, mas não igual / Mirella de Almeida Marino ; orientador, Luiz Claudio Mubarac. -- São Paulo, 2020.

1 v.: il.

Dissertação (Mestrado) - Programa de Pós-Graduação em Artes Visuais - Escola de Comunicações e Artes / Universidade de São Paulo Bibliografia

Versão original

1. Desenho 2. Gravura 3. Fotografia 4. Cidade 5. Cotidiano I. Mubarac, Luiz Claudio II. Título

CDD 21. ed. - 700 